\title{
Cohabitation, marriage and child outcomes
}

\section{IFS Commentary C114}

Alissa Goodman

Ellen Greaves

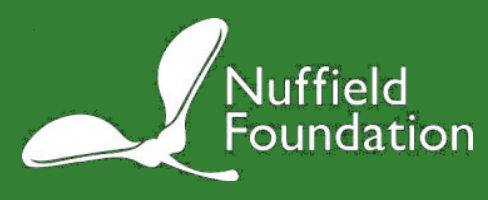




\title{
Cohabitation, marriage and child outcomes
}

\author{
Alissa Goodman \\ Ellen Greaves \\ Institute for Fiscal Studies
}

Copy-edited by Judith Payne

The Institute for Fiscal Studies

7 Ridgmount Street

London WC1E 7AE 


\section{Published by}

The Institute for Fiscal Studies 7 Ridgmount Street London WC1E 7AE

Tel: +44 (0)20 72914800

Fax: +44 (0)20 73234780

Email: mailbox@ifs.org.uk

Website: http://www.ifs.org.uk

(C) The Institute for Fiscal Studies, April 2010

ISBN: 978-1-903274-75-0 


\section{Preface}

The authors are very grateful to the Nuffield Foundation for supporting this work as part of a wider project, 'Births out of Wedlock and Cognitive and Social Development throughout Childhood: A Quantitative Analysis' (grant number CPF/37467).

The Nuffield Foundation is an endowed charitable trust that aims to improve social well-being in the widest sense. It funds research and innovation in education and social policy and also works to build capacity in education, science and social science research.

The Nuffield Foundation has funded this project, but the views expressed are those of the authors and not necessarily those of the Foundation. More information is available at http://www.nuffieldfoundation.org.

The authors would also like to extend their thanks to a number of colleagues who have helped them with this work. Particular thanks to Sharon Witherspoon for all her extremely insightful support. Many thanks also to Dan Anderberg, Mike Brewer, Stacey Chen, Claire Crawford, Hayley Fisher, Robert Joyce and Luke Sibieta for helpful discussions and comments on earlier drafts. The authors are also extremely indebted to participants at a seminar held at the Nuffield Foundation on 22 March 2010, and to an anonymous referee, whose suggestions have been extremely helpful.

All views expressed are those of the authors. 


\section{Contents}

$\begin{array}{ll}\text { Executive summary } & 1\end{array}$

$\begin{array}{ll}\text { 1. Introduction } & 7\end{array}$

2. Previous literature 10

$\begin{array}{lll}\text { 3. Data } & 15\end{array}$

4. Who marries and who cohabits? The characteristics of married parents compared 18 with cohabiting parents

4.1 Who marries and who cohabits? Characteristics that are fixed over time (Group 1) 20

4.2 Who marries and who cohabits? Characteristics mainly reflecting selection, but 22 potentially capturing causal pathways (Group 2)

4.3 Who marries and who cohabits? Characteristics that are possible causal pathways 26 (Group 3)

5. What are the outcomes of children born into married and cohabiting families, at ages 3 and 5 ?

6. What are the outcomes of children born to cohabiting compared with married parents, after controlling for observable differences?

6.1 Results: comparing outcomes of children born to cohabiting parents and children 35 born to married parents

6.2 Results: comparing outcomes of children according to their parents' relationship 40 status up to the age of 3

$\begin{array}{llr}\text { 7. Conclusions } & 45\end{array}$

$\begin{array}{ll}\text { Appendix tables } & 46\end{array}$

$\begin{array}{ll}\text { References } & \mathbf{7 5}\end{array}$ 


\section{Executive summary}

\section{Introduction}

- There has been a very large increase in the number of births to cohabiting parents in the last 25 years. In 2008, as many as 30\% of all births in England and Wales were registered to unmarried parents living at the same address.

- Previous commentators have observed that children living with married parents show better cognitive and behavioural outcomes than children living in other family forms, including cohabiting families. Very few studies, however, particularly from the UK, have discussed whether marriage per se causes these differences, and hence whether encouraging parents to get married, rather than to cohabit, will improve child outcomes.

- This issue is relevant to the current policy debate in the UK, as the incumbent Labour government and opposition Conservative Party diverge in their approach to formal marriage. The Conservatives have promised to 'recognise marriage and civil partnerships in the tax system', based, in part, on a belief that such family situations are better for children. By contrast, the current government believes that 'marriage is a personal and private decision for responsible adults, with which politicians should not interfere'.

\section{Previous literature}

- There is a wide previous literature, particularly from the US, which documents that children born to (and living with) cohabiting parents have worse outcomes than children whose parents are married. In seeking to explain such findings, many commentators have pointed to the fact that cohabiting parents are more likely to separate than married ones - with relationship instability associated with negative outcomes for children. Evidence on whether these differences can be given a causal interpretation is much less well developed, however.

- A small number of papers set out some reasons why formal marriage between parents might lead to better outcomes for children compared with cohabitation. These theoretical papers suggest that because formal marriage involves greater social and legal commitment, this might lead to greater cooperative behaviour between parents, might give women greater bargaining power over household resources or might reduce parental stress - all of which could lead to better child outcomes.

- The same theoretical papers also emphasise, however, that the issue of 'selection' into marriage is an important one. An individual's decision to marry will depend on many factors - for example, their existing level of happiness in their relationship, cultural norms and perhaps the socio-economic status of their partner. It is therefore reasonable to suppose that couples that choose to marry in the first place will have different characteristics from those that choose to cohabit. Some of these characteristics will be observable to researchers, but others - such as the degree of love and commitment within a relationship - will typically not be observable. Differences in outcomes between the children of married parents and those of cohabiting ones are likely at least partly to reflect these underlying observable and unobservable differences ('selection'), rather than being caused by parents' formal marital status itself. 
- Only one paper that we know of uses robust empirical methodologies that take into account the possibility of selection on both observed and unobservable characteristics, in order to try to estimate the causal effect of marriage compared with parental cohabitation on children. This paper finds that once observable and unobservable differences between married and cohabiting parents in Sweden are taken into account, marriages (at least those by parents responding to financial incentives) provide no educational advantage to children.

- In this Commentary, we are only partially able to address the 'selection' issue outlined above. We do this simply by examining the size of the gap in outcomes between children born to cohabiting parents and those born to married couples after controlling for observable factors. The factors we control for specifically are those that we believe are likely mainly to reflect the type of parents who decide to get married, and in our judgement are not likely to be greatly affected by the decision to get married (or not) itself.

\section{Data}

- Our study is based on the Millennium Cohort Study (MCS), a longitudinal study of children which initially sampled almost 19,000 new births across the UK around the year 2000, with follow-ups when the child was 9 months old, 3 years old and 5 years old. For our analysis, we use a sample of around 10,000 of these children, whose biological parents were married or cohabiting at the time of their birth, and for whom we have developmental measures at ages 3 and 5 .

- The measure of cognitive development we use is the verbal scale of the British Ability Scale (BAS), which assesses the spoken vocabulary of young children. The measure of social and emotional development is derived from a series of responses from the Strengths and Difficulties Questionnaire (SDQ). The SDQ battery of questions asks the parent to respond to questions about their child's development in four areas: emotion, conduct, hyperactivity and problems with peers.

- We consider two measures of relationship status between the biological parents of the child. Our first measure refers to the parents' relationship at the time of their child's birth. This information was asked of the main respondent of the survey retrospectively when the child was around 9 months old. Our second measure looks at the parents' relationship status both when the child was born and at the age of 3: it specifically records whether parents who were together at birth subsequently got married (where applicable), remained cohabiting (where applicable) or split up.

Who marries and who cohabits? The characteristics of married parents compared with cohabiting parents

- Couples choose to enter into marriage, and we show that couples that make this decision are observably different from couples that choose to cohabit:

- Ethnicity: Just over half of mothers who are Black Caribbean are married when the child is born, compared with about $70 \%$ of mothers who are White. By contrast, almost all mothers who are Bangladeshi, Pakistani or Indian are married when their child is born.

- Religion: Mothers of all religious faiths are significantly more likely to be married rather than cohabiting compared with mothers of no religion.

- Parental education: Both mothers and fathers in married couples are over twice as likely to have a degree as their counterparts in cohabiting couples. Married mothers are also slightly less likely to have problems reading in day-to-day life.

- Parental occupation: Fathers within married couples are twice as likely to have a professional occupation as cohabiting fathers. 
- Parental income and housing tenure: Couples that are married at the time of their child's birth are around twice as likely to be in the highest household income quintile, and a third as likely to be in the lowest household income quintile. Married couples are much more likely to own or have a mortgage for their home.

- Mother's age at birth of first child: Mothers in cohabiting couples are much more likely to have been a teenager at the time of their first child's birth: $18 \%$ of mothers in cohabiting couples first gave birth before they were 20 , compared with $4.2 \%$ of married mothers, while over $30 \%$ of married mothers were over 30 at the time of their first child's birth, compared with $21 \%$ of cohabiting mothers.

- Relationship duration prior to child's birth: Married couples are much more likely to have lived together for a longer period of time prior to their child's birth than cohabiting couples: over half of married couples have lived together for more than 6 years, compared with $16 \%$ of cohabiting couples prior to the birth of the child in the Millennium Cohort Study. Almost $40 \%$ of cohabiting couples had lived together for less than 2 years, compared with only $8 \%$ of married couples.

- Planned pregnancies: Mothers in married couples are much more likely to report that their pregnancy was planned; this was the case for $75 \%$ of married mothers compared with $47 \%$ of cohabiting mothers.

- Relationship quality: There is some difference in 'early' relationship quality between married and cohabiting couples. For example when the child is 9 months old, $31 \%$ of married mothers report that their partner is usually sensitive and aware of their needs, compared with $24 \%$ of cohabiting mothers.

- Relationship stability: Cohabiting couples are considerably more likely to experience a period of separation of a month or longer before their child is 3 years old; this is the case for $26 \%$ of cohabiting couples and only $7 \%$ of married couples. Couples that are cohabiting at the time of their child's birth, rather than being married, are also less likely to live together when their child is aged 3 .

- Mother and child health: Mothers who are married at the time of their child's birth and their child have slightly better health outcomes than mothers who are cohabiting. The child is slightly less likely to have a low birthweight (5.8\% of children born to married couples, compared with $7.4 \%$ born to cohabiting couples) and slightly less likely to have been born prematurely (7.7\% compared with $8.5 \%$ ). Mothers in cohabiting couples when their child is born are much more likely to smoke when the child is 9 months old: $41 \%$ of mothers in cohabiting couples smoke, compared with $15 \%$ of mothers in married couples. Mothers in cohabiting couples are also less likely to breastfeed their child at all, and slightly more likely to have a high score on an index of 'mother's malaise' when the child is 9 months old, which is indicative of depression.

- Parenting practices: Fathers in married couples are slightly more likely to have the lowest level of involvement with their child at 9 months old, but cohabiting fathers are less likely to rate themselves as 'good' or 'very good' parents when their child is aged 3: 57\% of fathers in married couples have this belief, compared with $44 \%$ of fathers in cohabiting couples. There is less difference in the percentage of mothers in each household type who believe they are 'good' or 'very good' parents. Couples that are married at the time of the birth are more likely to have a more regular routine for their child: $46 \%$ have a regular bedtime for the child at age 3 , compared with $39 \%$ of cohabiting couples. Married couples are also more likely to provide a better home learning environment at age 3 - for example, $67 \%$ read to their child daily, compared with $58 \%$ of cohabiting couples.

Married and cohabiting couples are also likely to differ in many other ways besides these - ways that are not observable to researchers but may also be important for child outcomes. 
What are the outcomes of children born into married and cohabiting families, at ages 3 and 5 ?

- By the time children are aged 3, there are already statistically significant differences in child outcomes between children born to married parents and those born to cohabiting parents. On average, children born to married parents display better social and emotional development and stronger cognitive development than children born to cohabiting parents.

- The differences in children's social and emotional development are much larger than the differences in their cognitive development at both age 3 and age 5 .

- The most negative outcomes for children are, on average, amongst those whose biological parents have split up, regardless of the formal marital status of the parents before they split.

- The differences we observe between children born to cohabiting parents and those born to married parents are relatively small in comparison with other attainment gaps, such as the gap between children born to parents with a high and low level of education, between children born to lone parents compared with parents in any form of couple, or between parents with high and low income.

What are the outcomes of children born to cohabiting compared with married parents, after controlling for observable differences?

- While we can see various differences in outcomes between the children of married and cohabiting parents, we need to examine whether these are plausibly caused by marriage itself or are caused by other factors. We do this by showing how controlling for parents' observable characteristics affects our estimates of the differences in cognitive and social and emotional outcomes between children born to married couples and those born to cohabiting parents.

- Caution is needed in interpreting our findings:

- Where the characteristics we control for purely reflect the type of people who decide to cohabit, rather than to get married, controlling for them helps us to partially deal with the selection issue, and hence to arrive at a better estimate of the causal impact of marriage on child outcomes.

- On the other hand, where these characteristics are ones that might be altered by being married, or cohabiting, then controlling for them helps us understand the extent to which they are the causal pathways through which cohabiting might lead to different outcomes for children, compared with being married.

- But almost all of the parental characteristics that we observe are likely both to reflect the sort of people who select into marriage and to be partly determined by the presence or absence of marriage in itself. In this case, interpreting our findings requires some judgement on the part of the reader. We provide our own judgement where necessary.

- The gap in cognitive development at ages 3 and 5 between children born to cohabiting parents and those born to married parents is greatly reduced and is no longer statistically significantly negative after differences in parents' education, occupation, income and housing tenure are controlled for. This suggests that the lower cognitive development of children born to cohabiting parents compared with children born to married parents is largely accounted for by their parents' lower education and income, and not by their parents not being married. 
- The gap in social and emotional development at ages 3 and 5 between children born to cohabiting parents and those born to married parents is reduced by more than half, but remains statistically significant, once differences in parental education and socio-economic status are controlled for. This suggests that the majority of the gap in social and emotional development of children born to cohabiting parents compared with children born to married parents is largely accounted for by their parents' lower education and income, and not by their parents not being married.

- Once the likelihood of a pregnancy being unplanned and the relationship quality when the child is $\mathbf{9}$ months old are also controlled for, the gap in social and emotional development between the children of married and cohabiting parents becomes yet smaller, and is now statistically insignificant. This suggests that the remainder of the difference in social and emotional development for children born to cohabiting compared with married couples is accounted for by differences in family structure (including lower rates of planned pregnancy) and lower relationship quality (early on in their life) for their parents.

- Our research here, however, cannot distinguish the extent to which these differences reflect the sort of people who choose to marry in the first place (since people are likely to choose to marry in part on the basis of the underlying quality of their relationship) and how much they are the positive product of marriage itself (possibly due to the additional social and legal protections provided by marriage).

- We also test for the importance of a number of potential additional causal pathways between parental cohabitation and low outcomes, including relationship instability, changes in income, maternal mental health and parenting styles. After controlling for the other observable characteristics in our model discussed above, we do not find any evidence that these are causal pathways between cohabitation and child outcomes.

- The clearest potential - but debatable - causal pathway between parents' formal marital status and children's social and emotional development allowed for by our work is therefore early relationship quality. To show that this is indeed a causal pathway, it would need to be established that marriage leads to large improvements in relationship quality by the time the child is 9 months old, which in turn lead to better social and emotional outcomes for children. This cannot be ascertained from our current study.

- Our findings are similar when we examine a more detailed classification of parents' relationship status, taking into account the fact that some cohabiting couples get married and others split up by the time the child is 3 .

\section{Conclusions}

- There is a vigorous academic and political debate about the benefits of marriage, which has partly focused on whether encouraging parents to formally marry, rather than to cohabit, will provide a better environment for children.

- We have shown that the children of married parents do better than the children of cohabiting parents in a number of dimensions, particularly on measures of social and emotional development at the ages of 3 and 5 .

- But we have also shown that parents who are married differ from those who are cohabiting in very substantial ways, particularly relating to their ethnicity, education and socio-economic status, and their history of relationship stability and the quality of their relationship even when the child is at a very young age. Once we take these factors into account, there are no longer any statistically significant differences in these child outcomes between children of married and cohabiting parents. 
- What is the policy significance of these findings? Our own work cannot conclusively determine whether a causal marriage effect exists. However, much of the gap in educational and social and emotional outcomes between the children of cohabiting and married parents appears to be due to differential selection into marriage compared with cohabitation on the basis of parental education and socio-economic status. Much of the remaining difference in social and emotional outcomes is directly linked to relationship quality. It is debatable whether this largely further reflects selection into marriage or reflects any positive benefits of marriage itself.

- For our research to indicate a significant positive causal effect of marriage, it would need to be shown that marriage leads to large improvements in parents' characteristics by the time the child is 9 months old, which in turn lead to better social and emotional outcomes for children. This seems unlikely in the case of parental education and socio-economic status. It is more debatable whether relationship quality is greatly affected by marriage, or instead whether relationship quality determines marriage. The role of housing tenure is also debatable: it largely reflects the couple's pre-existing wealth and commitment to the relationship, but could also be affected by the decision to marry.

- The next stage of our work will be based on an analysis of the children of the British Cohort Study, for whom we have measures of many more pre-existing parental characteristics that are usually unobserved (including parental cognitive and social skills, and parental relationship histories over the whole of their adult lives). We hope we can get closer to a definitive answer in this future work. 


\section{Introduction}

It is well known that children born to married parents achieve better outcomes, on average, both at school and in terms of their social and emotional development, than children born into other family forms, including into cohabiting unions. This Commentary documents in some detail how children's cognitive and social development differs between married and cohabiting parents, and provides a preliminary assessment of the extent to which such differences might be due to a causal effect of marriage itself. In so doing, it aims to inform a policy debate on the merits of encouraging individuals to enter marriage before they bear children, which has intensified in the run-up to the forthcoming general election.

According to official birth registry statistics, since the late 1970s there has been a very large increase in births outside marriage, particularly to cohabiting parents, in England and Wales. As many as $45 \%$ of all live births in England and Wales occurred outside marriage in 2008, a rate that has been rocketing in the last three decades, from less than $10 \%$ in the late 1970s. Of these, it is estimated that the majority amounting to almost three in ten of all live births - are to cohabiting parents. It is also interesting to note that almost all the rise in births out of wedlock since the late 1980s, when official records began to distinguish between cohabiting and lone-parent non-marital births, can be attributed to cohabiting parents. The proportion born to lone parents has risen only slightly over this time. (See Figure 1, from official Office for National Statistics (ONS) birth statistics.)

Figure 1. Outside-marriage live births (rate per 1,000 live births), 1845-2008

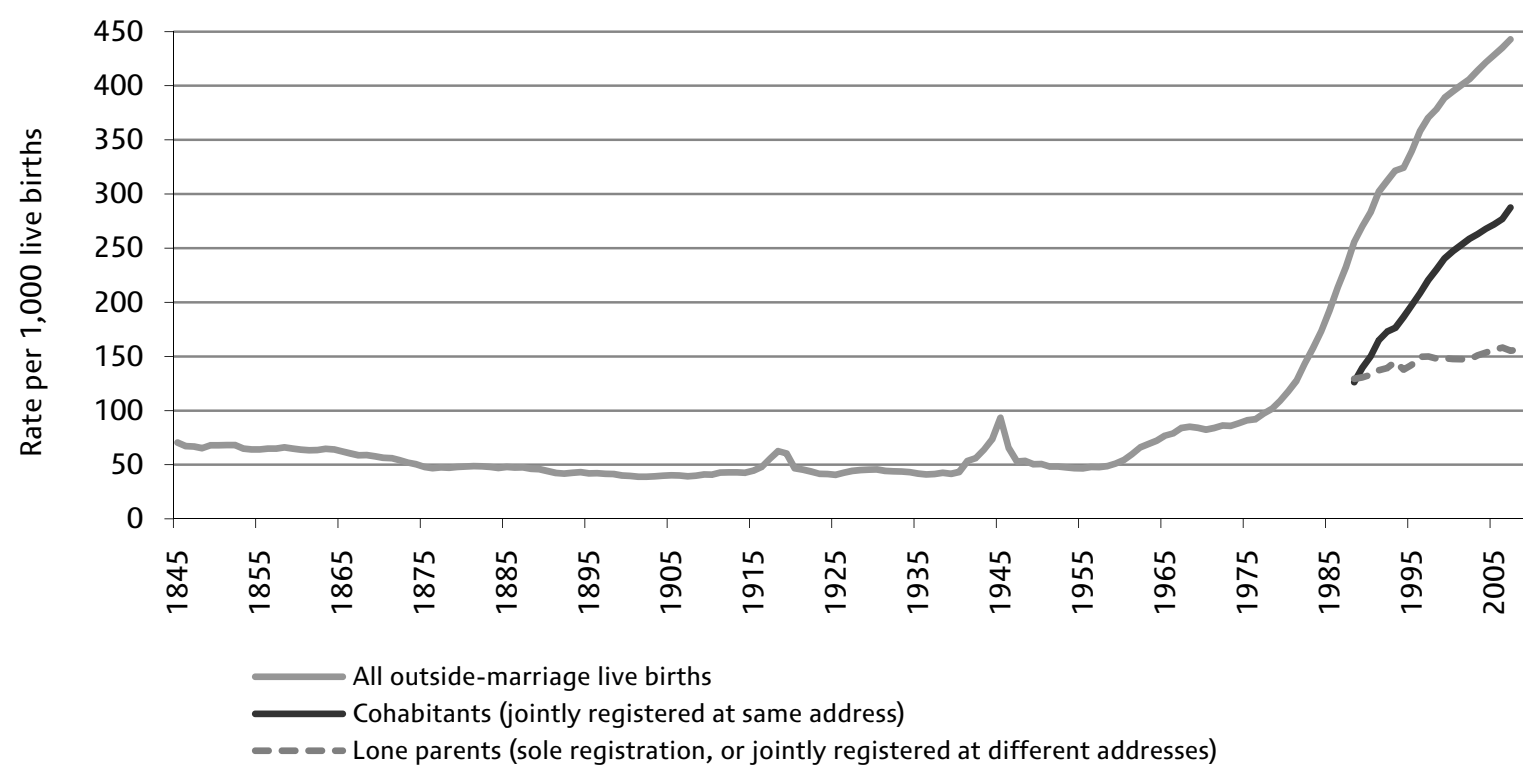

Sources: Office for National Statistics, Birth Statistics PBH11 Live Births, 1838-2004, occurrence within/outside marriage and sex. Office for National Statistics, Series FM1, editions 30 and 36, tables 1.1, 3.9 and 3.10; edition 37, tables 1.1b (corrected), 3.9 and 3.10 .

It has been suggested that the large growth in the number of children born into cohabiting unions in the UK - a trend also common in other countries - reflects a number of stages through which our society has been passing. Kiernan (2001) describes this as follows: initially, as non-marital cohabitation becomes more common, it tends to serve as a temporary and predominantly childless state, in which partners test the suitability of their relationship prior to marriage and subsequent childbearing; as time continues, however, cohabitation clearly becomes seen by many as an alternative to marriage, in which childbearing also commonly takes place. 
Understandably, the consequences of the growth in non-marital births for children's well-being, and their cognitive, social and emotional skills, have become the subject of considerable scrutiny. While numerous previous commentators have observed that children born to cohabiting parents have worse outcomes than those born to married couples, it is also widely recognised that marriage itself, or the absence of it, may not be the cause of this difference. Cohabiting couples with children may differ from married couples in many ways other than their formal marital status - for example, in their level of education, occupation, or love and commitment in the relationship. Differences in outcomes between children whose parents are married and those who cohabit may simply reflect these differences, rather than be caused by marriage, which is sometimes referred to as the 'selection issue'. There is remarkably little recent, systematic evidence from the UK that either sets out how the outcomes for children differ according to the family situation into which they are born or that attempts to explain these differences.

This lack of up-to-date UK evidence is particularly serious given how central this issue has become in the policy debates surrounding the forthcoming general election. In particular, the Conservative Party (2010) has proposed to 'recognise marriage and civil partnerships in the tax system', partly based on a belief that such family situations are better for children along a number of dimensions. By contrast, the current government believes that 'marriage is a personal and private decision for responsible adults, with which politicians should not interfere'. ${ }^{1}$

This Commentary aims to inform the ongoing policy debate by setting out clearly how outcomes differ between children whose parents are married and those who are cohabiting (i) around the time of their birth and (ii) in the first three years of their lives. It also sets out how children living within these different family forms differ in other observable dimensions, such as their ethnicity, socio-economic status and their parents' self-reported relationship quality. Finally, it shows what the gap between children from married and cohabiting backgrounds is, once these other dimensions are controlled for. By doing this simple statistical exercise, we hope to provide a clearer view of whether being born to married parents (or encouraging parents to marry after their child has been born, if they have not done so beforehand) might benefit children.

We emphasise that at this stage we can only hope to control for observable differences between children born into different family situations. As such, we do not fully address the 'selection issue' referred to above, which may arise as much because of unobserved differences between married parents and cohabitants (such as the strength of love or commitment between partners, or belief in the institution of marriage) as because of observed ones. We must also emphasise that in controlling for observable differences between parents, we cannot fully separate out those observable factors that purely reflect differential selection into marriage and those that might also reflect any positive (or negative) effects of marriage itself. For both these reasons, we cannot claim to be able to definitively measure the causal effects of parental marriage compared with cohabiting on child outcomes. This work represents the early stages of a wider project in which we hope to address these issues more fully. ${ }^{2}$

It is also worth emphasising that in this Commentary, we only consider differences between cohabiting and married biological parents; the issue as to whether it is better for a child's biological parent to marry or cohabit with a step-partner is beyond the scope of our research. ${ }^{3}$ A further limitation of our work is that we are only able to consider children's outcomes until age 5. This excludes any analysis of the impact

\footnotetext{
${ }^{1}$ Department for Children, Schools and Families, 2010.

${ }^{2}$ For more project details, see http://www.ifs.org.uk/projects/5/318.

${ }^{3}$ This limitation to our research is in part driven by the fact that there are only a small number of step-parent families appearing within the Millennium Cohort Study by the time the study children reach the age of 3. From the full sample of families (including lone parents but only looking at families for which children have all outcome measures available), only 435 families, or $3.8 \%$, are in step-parent families when the child is aged 3.
} 
of a parent's marital status as children age. This will be possible in future work where we will use different sources of data.

The structure of this Commentary is as follows.

- Chapter 2 sets out a summary of the previous empirical and theoretical literature on this topic.

- Chapter 3 describes the data used for this study.

- Chapter 4 addresses the question, 'Who marries and who cohabits?'. We answer this question by looking at differences in a number of dimensions, including parents' ethnicity, religion, education, socio-economic status, age, family size, relationship duration and relationship quality - all of these characteristics arguably might reflect differential selection into marriage compared with cohabiting. This section also examines differences in what might be thought of as a set of possible causal pathways or transmission mechanisms through which parents' formal relationship status might plausibly affect child development. These include: the stability of the relationship and, where the relationship continues, its ongoing quality; changes in family income and work status; maternal and child health, and family health-related behaviours; and parenting styles (including the home learning environment and parenting rules).

- Chapter 5 shows how children's cognitive outcomes and social and emotional outcomes at ages 3 and 5 differ according to whether their parents are cohabiting or married.

- Chapter 6 assesses the extent of the differences in cognitive outcomes and social and emotional outcomes between children whose parents are married and those who cohabit that remains once the observable factors from Chapter 4 are taken into account.

- Chapter 7 draws upon the analysis of the previous sections to conclude. 


\section{Previous literature}

There is an extensive empirical literature, mainly from the US, showing that children either born to or living with cohabiting parents fare worse academically and behaviourally when compared with children who are the product of married unions. ${ }^{4}$ In seeking to explain such findings, many commentators have pointed to the fact that cohabiting parents are more likely to separate than married ones, and that relationship instability is associated with negative outcomes for children. While the parallel evidence for the UK is much less extensive than the evidence for the US, the general tenor of the findings is similar, with the existing published evidence mainly emphasising relationship instability as a route via which being born into a cohabiting family leads to worse outcomes for children than being born to married parents. ${ }^{5}$

Such findings have led some commentators to conclude that the choice to cohabit rather than marry itself has damaging effects. For example, recent reports from the Centre for Social Justice emphasise the 'protective' nature of marriage compared with cohabitation for children. ${ }^{6}$ However, the evidence on the extent to which such differences can be given a causal interpretation is much less well developed, either theoretically or empirically. In other words, the literature is much less clear on whether the choice to parent as a cohabiting couple actually causes either greater relationship instability or poorer child outcomes, or whether other factors are at least partly responsible.

From a theoretical point of view, the vast majority of the social science literature on why marriage might have positive effects for children does not distinguish between marriage and cohabitation, instead contrasting the possible benefits of two-parent households compared with one-parent ones. ${ }^{7}$

A small number of papers do set out some theoretical reasons why formal marriage between parents might lead to greater investment in their children, which leads to better outcomes. We focus our discussion on the economics literature as it is our area of relative expertise. Here, commentators have pointed out that formal marriage entails greater legal and social commitments than cohabitation. As a result, marriage is generally more difficult to dissolve, both from a legal and a social perspective, than cohabitation. For example, in contrast to cohabiting relationships, ending a marriage requires legal separation of property and custody rights. It also entails a different balance of gains and losses between

\footnotetext{
${ }^{4}$ See, for example, Manning (2002), Brown (2004), Manning and Lamb (2003), Artis (2007), Manning and Lichter (1996), Graefe and Lichter (1999), Bumpass and Lu (2000), Smock and Gupta (2002), Manning, Smock and Majumdar (2004), Acs and Nelson (2002), Acs and Nelson (2003) and Acs and Nelson (2004).

${ }^{5}$ For example, Ermisch and Pronzato (2008) cites evidence from the British Household Panel Survey (BHPS) that only about $35 \%$ of children born into a cohabiting union will live with both parents until their 16 th birthday, compared with $70 \%$ of children born within a marriage. These findings are echoed in Kiernan (1999), who shows that children in Great Britain are more likely to see their parents separate if they are born to cohabiting rather than married parents, and in Benson (2006), who cites evidence from the Millennium Cohort Study (MCS) that cohabiting parents are much more likely to split up by the time a child is aged 3 than are married parents. The MCS data are also used by Kiernan and Mensah (2009) to document changes in household status by the time the child is aged 5, and Kiernan and Pickett (2006) show how parental marital status affects the quality of parenting in the very early stages of life, showing that cohabiting mothers are more likely to smoke during pregnancy, more likely to suffer from depression and less likely to breastfeed their babies. Andersson (2002) finds that across developed countries, those born to married parents typically have only half the probability of experiencing a family disruption during childhood, as compared with children born to cohabiting parents.

6 'The statistics indicate that marriages are far more likely to provide a stable environment for adults and children than cohabitation and are more resilient when the family is facing a crisis or stressful life event such as childbearing' (Social Policy Justice Group, 2006, p. 11).

${ }^{7}$ See Ribar (2004) for a very useful review and discussion.
} 
partners on dissolution (as well as on death). Table 1 provides further details of the differences in the legal system relating to married and cohabiting couples in England, Wales and Northern Ireland. ${ }^{8}$

Table 1. Differences in the legal system relating to married and cohabiting couples in England, Wales and Northern Ireland

\begin{tabular}{lll}
\hline \hline $\begin{array}{l}\text { Legal } \\
\text { arrangement }\end{array}$ & Marriage & Cohabitation \\
\hline $\begin{array}{l}\text { Parental } \\
\text { responsibility }\end{array}$ & $\begin{array}{l}\text { Both married parents have parental } \\
\text { responsibility for their child until the } \\
\text { child is 18 years old. This is the case } \\
\text { even if the couple separate or divorce. }\end{array}$ & $\begin{array}{l}\text { An unmarried mother has sole parental } \\
\text { responsibility for her child unless: } \\
\text { - the birth is registered jointly with the } \\
\text { child's father; or } \\
\end{array}$ \\
& $\begin{array}{l}\text {-a formal agreement with the child's } \\
\text { father is made and it is registered at } \\
\text { court; or } \\
\text { - there is a court order in favour of the } \\
\text { father. }\end{array}$ \\
&
\end{tabular}

\begin{tabular}{|c|c|c|}
\hline $\begin{array}{l}\text { Contact with } \\
\text { children }\end{array}$ & \multicolumn{2}{|c|}{$\begin{array}{l}\text { No difference. If the couple separate, then they can make an informal arrangement } \\
\text { for contact with their child. If an informal arrangement is not possible, then a court } \\
\text { may be asked to intervene. }\end{array}$} \\
\hline $\begin{array}{l}\text { Financial support } \\
\text { of children }\end{array}$ & \multicolumn{2}{|c|}{ No difference. Both parents are responsible for supporting the child financially. } \\
\hline Inheritance & $\begin{array}{l}\text { If either married partner dies without } \\
\text { making a will, the other will inherit all } \\
\text { or some of the estate. } \\
\text { Money or property inherited from a } \\
\text { married partner is exempt from } \\
\text { inheritance tax. }\end{array}$ & $\begin{array}{l}\text { If one partner dies without leaving a will, } \\
\text { the surviving partner will not } \\
\text { automatically inherit anything unless the } \\
\text { couple owned property jointly. } \\
\text { Money or property inherited from an } \\
\text { unmarried partner is not exempt from } \\
\text { inheritance tax. }\end{array}$ \\
\hline Capital gains tax & $\begin{array}{l}\text { Gifts between husband and wife are } \\
\text { not subject to capital gains tax. } \\
\text { Tax-free allowances can be combined if } \\
\text { an asset is transferred to joint } \\
\text { ownership between husband and wife. }\end{array}$ & $\begin{array}{l}\text { Cohabiting couples are not exempt from } \\
\text { capital gains tax when transferring assets } \\
\text { between them. }\end{array}$ \\
\hline $\begin{array}{l}\text { Ending the } \\
\text { relationship }\end{array}$ & $\begin{array}{l}\text { To end the marriage formally, a } \\
\text { married couple must go to court and } \\
\text { get divorced. }\end{array}$ & $\begin{array}{l}\text { An unmarried couple can separate } \\
\text { informally without the intervention of a } \\
\text { court. The court does have power to make } \\
\text { orders relating to the care of the children. }\end{array}$ \\
\hline Financial support & $\begin{array}{l}\text { Each married partner has a legal duty } \\
\text { to support the other financially. }\end{array}$ & $\begin{array}{l}\text { Neither partner has a legal duty to } \\
\text { support the other financially. }\end{array}$ \\
\hline Housing & $\begin{array}{l}\text { Tenants: Both married partners have } \\
\text { the right to live in the matrimonial } \\
\text { home if they split up, whether they are } \\
\text { sole or joint tenants. } \\
\text { Owner-occupiers: Both married } \\
\text { partners have a right to remain in the } \\
\text { matrimonial home if they split up, } \\
\text { regardless of who bought it or has a } \\
\text { mortgage on it. }\end{array}$ & $\begin{array}{l}\text { Tenants: The partner of a sole tenant has } \\
\text { no legal right to remain in the home if } \\
\text { they split up. } \\
\text { Owner-occupiers: The partner of a sole } \\
\text { owner-occupier has no legal right to } \\
\text { remain in the home if they split up. If the } \\
\text { property is jointly owned, then both } \\
\text { partners have equal rights to stay in the } \\
\text { home. }\end{array}$ \\
\hline $\begin{array}{l}\text { Money and } \\
\text { possessions }\end{array}$ & $\begin{array}{l}\text { The property owned by each partner } \\
\text { will be taken into account when } \\
\text { arriving at a financial settlement on } \\
\text { divorce. }\end{array}$ & $\begin{array}{l}\text { The person who bought an item generally } \\
\text { owns it. It will be owned jointly if bought } \\
\text { from a joint account. }\end{array}$ \\
\hline
\end{tabular}

\footnotetext{
${ }^{8}$ These arrangements are somewhat different in Scotland.
} 


\begin{tabular}{|c|c|c|}
\hline $\begin{array}{l}\text { Legal } \\
\text { arrangement }\end{array}$ & Marriage & Cohabitation \\
\hline Debts & \multicolumn{2}{|c|}{$\begin{array}{l}\text { No difference. Partners are liable for any debts that are in their own name only. } \\
\text { Partners may be responsible for the whole of debts in joint names and for other } \\
\text { debts for which they have 'joint and several' legal responsibility. If a partner is } \\
\text { married, they will not be responsible for any financial obligations or debts that their } \\
\text { partner had before they were married. }\end{array}$} \\
\hline \multirow[t]{2}{*}{ Pension } & \multirow{2}{*}{$\begin{array}{l}\text { Occupational pension schemes must } \\
\text { offer equal benefits for husbands and } \\
\text { wives. }\end{array}$} & $\begin{array}{l}\text { Some occupational pension schemes will } \\
\text { offer benefits to a dependent partner. }\end{array}$ \\
\hline & & $\begin{array}{l}\text { An 'expression of wishes' form can } \\
\text { transfer benefits from a personal pension } \\
\text { to a partner if the other partner dies. }\end{array}$ \\
\hline $\begin{array}{l}\text { Welfare benefits } \\
\text { and tax credits }\end{array}$ & \multicolumn{2}{|c|}{$\begin{array}{l}\text { No difference. All couples, whether married or living together, are treated in the } \\
\text { same way when they are assessed for entitlement to welfare benefits, working tax } \\
\text { credit or child tax credit. They will be expected to claim as a couple, and the } \\
\text { income, savings and financial needs of both partners are taken into account. }\end{array}$} \\
\hline \multirow[t]{2}{*}{ Income tax } & \multicolumn{2}{|c|}{$\begin{array}{l}\text { No difference. Each partner is taxed separately and each partner is entitled to a } \\
\text { personal allowance when calculating how much income tax they must pay. }\end{array}$} \\
\hline & \multicolumn{2}{|c|}{$\begin{array}{l}\text { Except: where at least one person in a married couple was born before } 6 \text { April 1935, } \\
\text { a married couple's allowance can be claimed as well as the personal allowance. }\end{array}$} \\
\hline
\end{tabular}

Note: Information is for England, Wales and Northern Ireland.

Source: http://www.adviceguide.org.uk/index/your family/family/living_together_and marriage_legal differences.htm.

From the point of view of economic theory, if any of these aspects of formal marriage leads to greater cooperative behaviour between parents within their partnership (perhaps because they view their relationship to be less at risk of dissolving), then this could provide for greater investments in children than cohabitation. ${ }^{9}$ In addition, some models allow for the idea that if formal marriage gives women greater bargaining power over household resources than cohabitation - due to greater financial protection on separation. This could also lead to greater investments in children; Rangel (2006) finds evidence that the introduction of alimony rights and obligations to cohabiting couples in Brazil led to improved educational outcomes for children. A number of non-economics papers also emphasise the possibility of greater parental stress within cohabiting partnerships, if they are perceived to be less permanent. Artis (2007) writes that '[The] ambiguity and impermanence [associated with cohabitation] creates stress in the family unit that may lead to poor mental health, poor relationship quality, family instability and less effective parenting practices'. Citing Conger and Elder (1994), Artis notes that these factors 'may in turn negatively affect child development'.

On the other hand, the theoretical literature also highlights the importance of 'selection' into marriage is an important one. This selection arises because couples will choose whether to cohabit or marry, depending on which state they anticipate to be the best for them and for the well-being of their children. In particular, couples who perceive their relationship to be of higher quality and hence more long-lasting are more likely to commit to marriage than those who do not. ${ }^{10}$ As Ribar (2004) puts it, 'couples who face good prospects within marriage are likely to marry, while couples who face bad prospects are not'. In a theoretical model, Ermisch (2005) predicts that women with 'poorer' attributes are more likely to have a child outside of marriage, which would clearly be reflected in selection. Women with poorer attributes have a lower opportunity cost of childbearing as their earnings are lower, and so they have more incentive to have a child before waiting for marriage. They may also expect to attract a potential partner with poorer attributes than 'high charm' women, which again reduces the incentive to wait for a match in the marriage market.

\footnotetext{
${ }^{9}$ See Nordblom (2004) and Björklund, Ginther and Sundström (2007).

${ }^{10}$ Brien, Lillard and Stern, 2006.
} 
This non-random selection into marriage creates an empirical challenge for researchers attempting to investigate the causal effects of marriage as opposed to cohabitation on child outcomes. This is because cohabiting parents are likely to differ from married ones in many ways besides their formal marital status. For example, they are typically observed to be less educated and younger and to have a lower household income than married parents. ${ }^{11}$ As already discussed, they may also differ in less easily observable ways - for example, in their beliefs and values, the relationship quality, stability and commitment to their partner before their child's birth. Marriage may partly reflect these differences, rather than cause them.

Empirically, researchers have struggled to find strategies that adequately deal with this selection issue. A number of studies have taken into account observable differences between married and cohabiting parents, through simple regression analysis. (This is the approach we adopt in this Commentary.) These papers largely originate from the US and, to our knowledge, none has done this simple exercise yet among a group of contemporary children in the UK. Papers adopting this approach typically find that any apparent benefit to children from formal marriage compared with parental cohabitation is very much reduced, or disappears when observable differences are controlled for. ${ }^{12}$ It is possible to control for too many background characteristics of the parent, however; Ribar (2004) notes that while researchers need to be careful to control for underlying factors that are both correlated with the decision to marry and lead to better child outcomes, in so doing they must not inadvertently control away any positive indirect effects of marriage. Specific examples would be that if marriage itself actually causes higher income, better relationship quality or better parenting practices, then controlling for these indirect effects will lead to an understatement of the possible benefits of marriage.

While several studies do try to address the issue of selection on observable characteristics, very few studies indeed have been able to take into account the strong possibility of 'selection on unobservable characteristics'. One exception is that by Björklund, Ginther and Sundström (2007), who use the temporary marriage boom created by Sweden's widow's pension reforms of 1989 as an instrument for the marriage decision, in a model of children's education outcomes in Sweden. Their findings indicate no causal effect of parental marriage over cohabitation on Swedish children's education outcomes, suggesting that, within the Swedish context at least, marriage by parents who are responding to a financial incentive provides no educational advantage to children.

There are a few papers that use similar methodologies to consider the impact of marriage compared with cohabitation on adult outcomes. For example, Fisher (2010) examines the impact of marriage versus cohabitation on adult health. She uses differences in US marriage tax penalties or subsidies that provide the incentive for couples to marry rather than cohabit as an instrument for the decision to marry, and finds that, after controlling for selection, married couples do not see better health outcomes than unmarried cohabiting couples. Indeed, for women, marriages by individuals who are responding to financial incentives lead to poorer health compared with cohabiting. These findings contrast to those of other studies, which generally have considered whether there are advantages to being married compared with being single, widowed or divorced. Such studies typically find some health advantage to being married compared with having no 'significant other'.

Another area where researchers have attempted to address the issue of selection is in the related study of effects of premarital cohabitation on the probability of subsequent marital breakdown. While it is widely observed that couples who cohabit before they get married are more likely to subsequently divorce, a number of studies using econometric techniques that attempt to take into account selection effects - here

\footnotetext{
${ }^{11}$ Acs, 2007; Björklund, Ginther and Sundström, 2007; Manning and Brown, 2006; Acs and Nelson, 2004; Manning and Lamb, 2003; McLanahan and Sandefur, 1994.

${ }^{12}$ For example, Brown (2004).
} 
by obtaining econometric identification through assumptions about functional form and through exploiting the incidence of multiple marriages for some individuals - find that the apparently negative effects of pre-marital cohabitation on marital dissolution disappear when selection effects are controlled for. ${ }^{13}$

The main reason why so few empirical studies examining the implications of parental cohabitation for child outcomes have addressed the selection issue adequately is that the information required to employ appropriate methodological strategies is very hard to come by. Such approaches are essentially only possible if there are factors that affect parents' decision to marry rather than to cohabit, but that do not affect their children's development through any other channels (providing so-called exogenous variation in marital status). ${ }^{14}$ For example, such variation might arise from policy reforms that alter the incentive for individuals to be married, relative to cohabiting. This variation is not present in the recent UK tax and benefits system, however, as married and cohabiting parents are treated as equal (see Table 1 earlier).

In this Commentary, we build on the existing literature outlined above by examining differences in child outcomes between married and cohabiting biological parents among a contemporary cohort of young children (born in 2000 and 2001) in the UK. We are only partially able to address the 'selection' issue outlined here. We do this simply by controlling for observable characteristics of the parents: specifically, those that we believe are likely to be correlated both with the decision of whether to get married or cohabit and with subsequent child outcomes. In so doing, we try to control only for pre-birth or very early life factors, in order not to 'over-control' for the indirect effects of marriage in our analysis.

One of the strengths of our analysis is that the data source we use - the Millennium Cohort Study - is very rich in observable characteristics compared with the data employed by many of the other studies cited here. For example, we have information on many commonly unobserved factors, such as the parents' relationship duration prior to the child's birth, the mother's self-rated relationship quality when the child is 9 months old, and again at ages 3 and 5, and other factors such as whether the pregnancy was planned. There will certainly be other factors that remain unaccounted for, and we therefore cannot claim to be estimating a true 'marriage effect'. We do hope, however, that our work fills an important gap in the UK literature on parental cohabitation, and should help inform the policy debate over the merits of encouraging parental marriage over cohabitation as an environment in which to raise children.

\footnotetext{
${ }^{13}$ See Lillard, Brien and Waite (1995) and Bruderl, Diekmann and Engelhardt (1999).

${ }^{14}$ Other common approaches to the identification of endogenous parameters, such as fixed effects methods, are generally not applicable in this context.
} 


\section{Data}

Our analysis focuses on early developmental outcomes for children born around 2000 using the Millennium Cohort Study (MCS). This is a longitudinal data set which initially sampled almost 19,000 new births across the UK. ${ }^{15}$ Sampling took place between 1 September 2000 and 31 August 2001 in England and Wales and between 22 November 2000 and 11 January 2002 in Scotland and Northern Ireland. The sample design disproportionately selected families living in areas of child poverty, in the smaller countries of the UK and in areas with high ethnic minority populations in England.

The first survey of the MCS was taken when the child was around 9 months old, and was designed to chart the initial social and economic background of the child's family. This initial survey included detailed questions about the relationship between the biological parents at the time of the survey, and also looked back at relationship status at the time of the birth. Subsequent surveys were taken when the child was around age 3 (referred to as wave 2) and around age 5 (referred to as wave 3 ). These surveys contain information on how the family structure and broader circumstances changed over time, as well as assessments of the child's cognitive and behavioural development.

Below, we discuss our choice of sample for analysis, and how we measure child developmental outcomes and parents' relationship status. Table 2 provides an overview of these variables, while a full summary of all the variables used in our models is set out in Appendix Table A1.

\section{Choosing the analysis sample}

We only include in our sample children for whom we have measures of household composition at the time of the child's birth and when the child is 3 years old, as well as measures of cognitive and behavioural development of the child at ages 3 and 5. Additionally, for our analysis sample, we only include children whose parents were in a married or cohabiting couple when their child was born. Although the impact of other family forms, such as lone parenthood, is also clearly of interest, our main focus in this Commentary is to inform the policy debate around whether formal marriage between parents is better for children than parental cohabitation. After making these restrictions, our analysis sample includes around 10,000 observations. ${ }^{16}$

\section{Measuring child development}

The MCS conducted its own assessments of the children's development, taken first when the child was aged 3 and repeated when the child was aged 5 . The measure of cognitive development is the verbal scale of the British Ability Scale (BAS), which assesses the spoken vocabulary of young children. We compute an age-adjusted measure of the BAS, ${ }^{17}$ which we then standardise on the sample of children who have all outcome measures available, and whose parents have non-missing relationship status at birth and when the child is 3 years old. Note that the sample against which this outcome measure is standardised is

\footnotetext{
${ }^{15}$ More information about the MCS can be found at http://www.cls.ioe.ac.uk/text.asp? section=000100020001.

${ }^{16}$ A total of 16,919 families completed the MCS survey when their child was aged 5 . Of these families, 11,460 have measures of the child's development at ages 3 and 5 , and measures of household composition at birth and at age 3 . We use this sample of families to standardise our outcome measures for children's development and relevant household characteristics (our standardisation sample). In these families, 9,951 of the couples were married or cohabiting when the child in the MCS was born, and so are relevant to our analysis. We call this our analysis sample. The children of couples that were cohabiting at the time of their child's birth are 13 percentage points less likely to remain in the survey by the time the child is aged 5 than the children of couples that were married when their child was born. Children of couples that were cohabiting at birth are only 5 percentage points less likely than the children of couples that were married when their child was born to have all outcomes and household status measures recorded, and therefore to be included in our standardisation sample.

${ }^{17}$ This process uses an unweighted ordinary least squares regression to find the impact of a child's age in months on their assessment score. The residuals from this regression are used as the age-adjusted measure of cognitive development.
} 
broader than our analysis sample, as our analysis sample includes children of married and cohabiting couples only. The measure of behavioural development is derived from a series of responses from the Strengths and Difficulties Questionnaire (SDQ). The SDQ battery of questions asks the parent to respond to questions about their child's development in four areas: emotion, conduct, hyperactivity and problems with peers. The total SDQ score is the total of these four areas. Again, we standardise this measure on the sample of children who have all outcome measures available, and whose parents have non-missing relationship status at birth and when the child is 3 years old. Standardising both the cognitive and behavioural measures of development allows us to compare development across domains and ages. We can therefore identify whether gaps in attainment between children of married and cohabiting couples are greater at different ages, and whether cognitive gaps are larger or smaller than behavioural ones.

\section{Measuring relationship status}

Our first classification of the relationship between the biological parents of the child refers to their relationship at the time of their child's birth. This information was asked of the main respondent to the survey retrospectively when the child was around 9 months old. If applicable, the survey also asked the main respondent to give dates of when the period of cohabitation and/or marriage began. Where there was a discrepancy between the relationship reported at birth and the dates of cohabitation, we adjusted relationship status at birth accordingly. ${ }^{18}$ Table 3 shows that around $70 \%$ of our analysis sample were married when their child was born and $30 \%$ were cohabiting. These proportions are remarkably similar to official birth registration data from England and Wales in 2000, which showed that births within marriage accounted for $71 \%$ of all births to couples. ${ }^{19}$

Our second classification of the relationship between the biological parents of the child refers to their relationship at the time of their child's birth in relation to their relationship when their child is around age $3 .^{20}$ We group couples into those that were: (i) married when the child was born and when the child was aged 3; (ii) married when the child was born but had separated when the child was aged 3; (iii) cohabiting when the child was born but were married when the child was aged 3; (iv) cohabiting when the child was born and when the child was aged 3; and (v) cohabiting when the child was born but had separated when the child was aged 3 . Table 3 shows that around $95 \%$ of couples who were married when their child was born remained so by the time the child was 3, while around 5\% had split up. Among those couples who were cohabiting at the time of their child's birth, 53\% were still cohabiting, 27\% had got married and $19 \%$ had split up by the time the child was 3 .

\footnotetext{
${ }^{18}$ For example, if the main respondent reports that they were cohabiting with the other biological parent at birth, and they live together at wave 1, but the dates indicate that they did not begin living together until 2 months after the birth, then we recode the relationship to 'involved' at birth. If the dates indicate that the couple started living together less than 2 months after the birth and they are still together at wave 1, then we leave the couple as cohabiting at birth. This was necessary only in a minority of cases, however: we adjusted the relationship status at birth for all relationship types in only $3.29 \%$ of cases.

${ }^{19}$ This figure was calculated from data from the ONS Birth Statistics for 2000 (see http://www.statistics.gov.uk/downloads/theme population/Fm1 29/FM1 29 v3.pdf: table 3.1 shows the number of births to mothers within marriage, while table 3.10 shows the number of births outside marriage that were jointly registered by parents living at the same address).

${ }^{20}$ We infer relationship status at age 3 primarily through the household grid. The household grid contains a record of all people in the household and each person's relationship to the child and to all other members in the household. From this, we can look at how many biological parents of the child are in the household. If two biological parents are present in the household, then we can also look at their marital status - for example, 'spouse' or 'partner'. We also check our definition of household status when the child is aged 3 by corroborating with other questions in the survey. For example, some questions are asked only to main respondents with a partner in the household, and some questions are only relevant to those who have got married.
} 
Table 2. Primary variables of interest in the analysis

\begin{tabular}{|c|c|}
\hline Variables & Description \\
\hline \multicolumn{2}{|l|}{ Outcome variables } \\
\hline British Ability Scale (age 3) & Vocabulary element, standardised on our sample. \\
\hline Strengths and Difficulties (age 3) & Standardised on our sample. \\
\hline British Ability Scale (age 5) & Vocabulary element, standardised on our sample. \\
\hline Strengths and Difficulties (age 5) & Standardised on our sample. \\
\hline \multicolumn{2}{|l|}{ Relationship status } \\
\hline Household status at birth & $\begin{array}{l}\text { We create a variable that distinguishes between those who are } \\
\text { married and living together at the time of the birth and those } \\
\text { who are cohabiting at the time of the birth. We do not keep } \\
\text { any other family types in our sample. }\end{array}$ \\
\hline Household status at age 3 & $\begin{array}{l}\text { We create a variable for whether couples that were married at } \\
\text { the time of their child's birth stayed together or split up, and } \\
\text { whether couples that were cohabiting at the time of the birth } \\
\text { stayed together, got married or split up. }\end{array}$ \\
\hline
\end{tabular}

Table 3. Analysis sample by relationship status at birth and at age 3

\begin{tabular}{lcc}
\hline & $\mathbf{N}$ & \% (weighted) \\
\hline Married couples at birth & 7,053 & 70.1 \\
Of whom: & 6,731 & 95.2 \\
Remained married by age 3 & 322 & 4.8 \\
Split up by age 3 & 2,898 & 29.9 \\
\hline Cohabiting couples at birth & & \\
Of whom: & 1,580 & 53.2 \\
Remained cohabiting by age 3 & 771 & 26.6 \\
Got married by age 3 & 547 & 18.9 \\
Split up by age 3 & 9,951 & \\
\hline Total analysis sample & & \\
\hline \hline
\end{tabular}

Note: Percentages are weighted using sample weights supplied with the MCS data, which adjust for sample design and nonresponse. 


\section{Who marries and who cohabits? The characteristics of married parents compared with cohabiting parents}

Couples make a conscious choice whether to marry or cohabit. An individual's decision to marry will depend on many factors: their existing level of happiness in their relationship, cultural norms or perhaps the socio-economic status of their partner, for example. It is therefore reasonable to suppose that couples who choose to marry may have different characteristics from those who choose not to marry. Indeed, this 'selection' issue has been documented by a number of researchers (see Chapter 2 for a fuller discussion).

In this section, we explore the 'selection' of couples into marriage by looking at differences in the observable characteristics of married and cohabiting couples in our analysis sample. We group these observable characteristics into three subsets (and the full set of variables included in these subsets is listed in Table 4):

Group 1: characteristics that are fixed over time, and so should not be influenced by marriage (described in Section 4.1). We can be confident that these variables will reflect the selection of parents into cohabitation or marriage (i.e. the different sorts of people who decide to get married or not).

- Ethnicity is a clear example. The likelihood of marriage varies significantly by ethnic background, but it is impossible that marriage itself can change an individual's ethnicity.

Group 2: characteristics that are reasonably fixed over time, and are arguably largely determined before most people marry (described in Section 4.2). While our judgement is that these variables partly reflect selection, they may also be influenced by marriage itself, and hence potentially also capture causal pathways for the impact of marriage on child outcomes.

- Income is one example. While an individual's earning potential is mainly determined by aspects of their skills and abilities that are not directly altered by their formal marital status, there is also a considerable literature debating whether formal marriage might also boost individuals' earning power and productivity (see further discussion below).

- Relationship quality is another very important example. While the underlying quality of the relationship is likely to be an important factor that individuals take into account in deciding whether or not to get married, marriage itself might affect relationship quality.

Group 3: characteristics that vary over time, and so could be influenced by marriage (described in Section 4.3). These variables represent possible causal pathways for the impact of marriage on child outcomes - though they may also partly reflect selection.

- Relationship separation is an example. Since it is harder to dissolve marriages than cohabiting relationships, marriage might be expected to directly cause some relationships that might otherwise break down, to continue. However, the lower incidence of relationship breakdown among married couples may also be indicative of the level of commitment to the relationship prior to the child's birth, which in turn influenced the decision of whether or not to marry. We note, therefore, that even characteristics in the third group may also reflect differential selection to some extent. 
Table 4. List of variables that are included in the analysis, by group classification

\begin{tabular}{|c|c|c|}
\hline Group 1 & Group 2 & Group 3 \\
\hline \multirow{24}{*}{$\begin{array}{l}\text { Mother's ethnicity } \\
\text { Immigrant status (mother and } \\
\text { grandparents) } \\
\text { Mother's religion (9 months) } \\
\text { Mother was in care as a child } \\
\text { Mother's parents separated } \\
\text { Step- or half-children of mother } \\
\text { (or father) live in the household }\end{array}$} & Mother's and father's education & Relationship quality (self- \\
\hline & Whether mother has problems & reported, 3 and 5 years) \\
\hline & reading & Relationship stability (still \\
\hline & National Statistics Socio- & together at age 3 and age 5 , any \\
\hline & $\begin{array}{l}\text { Economic Classification (father, } \\
9 \text { months) }\end{array}$ & $\begin{array}{l}\text { period of separation longer than } \\
\text { one month before age } 3 \text { ) }\end{array}$ \\
\hline & Housing tenure (9 months) & Re-partnered (age 3 and age 5) \\
\hline & $\begin{array}{l}\text { Household income (standardised } \\
\text { and categorised into quintiles, } 9\end{array}$ & $\begin{array}{l}\text { Mother's employment status } \\
\text { (age } 3 \text { and age 5) }\end{array}$ \\
\hline & months) & Household income (standardised \\
\hline & Employment status (9 months) & and categorised into quintiles, 3 \\
\hline & $\begin{array}{l}\text { Age at first child (mother and } \\
\text { father) and father's current age } \\
\text { ( } 9 \text { months) }\end{array}$ & $\begin{array}{l}\text { years) } \\
\text { Birthweight and gestation of } \\
\text { child }\end{array}$ \\
\hline & Multiple-birth household & Whether mother has ever \\
\hline & $\begin{array}{l}\text { Length of cohabitation prior to } \\
\text { birth }\end{array}$ & $\begin{array}{l}\text { currently smokes, whether } \\
\text { anyone in the house smokes }\end{array}$ \\
\hline & Unplanned pregnancy (self- & around the child (9 months) \\
\hline & $\begin{array}{l}\text { reported, } 9 \text { months) } \\
\text { Birth order of child in the MCS }\end{array}$ & $\begin{array}{l}\text { Length of breastfeeding ( } 9 \\
\text { months) }\end{array}$ \\
\hline & $\begin{array}{l}\text { survey } \\
\text { Frequency of contact with } \\
\text { grandmother }\end{array}$ & $\begin{array}{l}\text { Index of mother's malaise } \\
\text { (indicating depression, } 9 \\
\text { months) }\end{array}$ \\
\hline & Relationship quality (self- & Child read to daily (3 years) \\
\hline & & $\begin{array}{l}\text { Father's involvement with the } \\
\text { child (standardised and } \\
\text { categorised into quintiles, } 9 \\
\text { months) }\end{array}$ \\
\hline & & $\begin{array}{l}\text { Home learning environment } \\
\text { (standardised and categorised } \\
\text { into quintiles, age } 3 \text { and age } 5 \text { ) }\end{array}$ \\
\hline & & $\begin{array}{l}\text { Self-rated parent ability } \\
\text { (mother and father, age } 3 \text { ) }\end{array}$ \\
\hline & & Regular bedtime (age 3) \\
\hline & & Regular mealtime (age 3) \\
\hline & & $\begin{array}{l}\text { Many rules in the household } \\
\text { (age 3) }\end{array}$ \\
\hline & & $\begin{array}{l}\text { Rules are strictly enforced (age } \\
\text { 3) }\end{array}$ \\
\hline & & $\begin{array}{l}\text { Child watches more than } 3 \\
\text { hours of TV per day (age } 3 \text { ) }\end{array}$ \\
\hline
\end{tabular}


In Appendix Table A2, we provide results from a multivariate regression model examining how the characteristics described in Table 4 are associated with the probability of being married compared with cohabiting. This allows us to investigate what significant differences in observable characteristics remain between married and cohabiting parents, when all the factors in our model are controlled for together. In summary, this analysis shows that couples are more likely to be married if:

- mother is of Indian, Pakistani or Bangladeshi ethnicity;

- mother is religious;

- mother's parents did not separate;

- there are no children of previous partners in the household;

- mother and father have a high level of education;

- parents own their own home;

- mother was 20 or older when her first child was born;

- the couple lived together for longer prior to the child's birth;

- the pregnancy was planned;

- there is more than one child in the household;

- the parents have a higher relationship quality when the baby is 9 months old.

In terms of the possible causal pathways for the impact of marriage, our results suggest couples that are married have:

- children with a higher birthweight and shorter gestation;

- a lower probability of the mother smoking when the baby is 9 months old;

- a higher level of father's involvement with the baby at 9 months;

- a higher likelihood of setting regular bedtimes at the age of 3 .

In Chapters 5 and 6, we analyse the extent to which differences in these characteristics can help to account for differences in cognitive, and social and emotional, development in children born to married and cohabiting couples. Before we do this, however, we describe in more detail how married and cohabiting couples differ in terms of their observable characteristics, categorised by the groups described in Table 4.

\subsection{Who marries and who cohabits? Characteristics that are fixed over time (Group 1)}

Figure 2 shows the percentage of mothers from each ethnic group who are married. Around $70 \%$ of mothers who are White are married at the time of their child's birth. In contrast, just over half of mothers who are Black Caribbean are married when the child is born, while almost all mothers who are Bangladeshi, Pakistani or Indian are married when their child is born. These differences may reflect cultural norms or wider circumstances of the families. As ethnicity is a fixed characteristic of the mother, and is also correlated with children's development at young ages, it is important to control for this variable in later analysis. 
Figure 2. Who marries and who cohabits? The probability of marriage for different ethnic groups

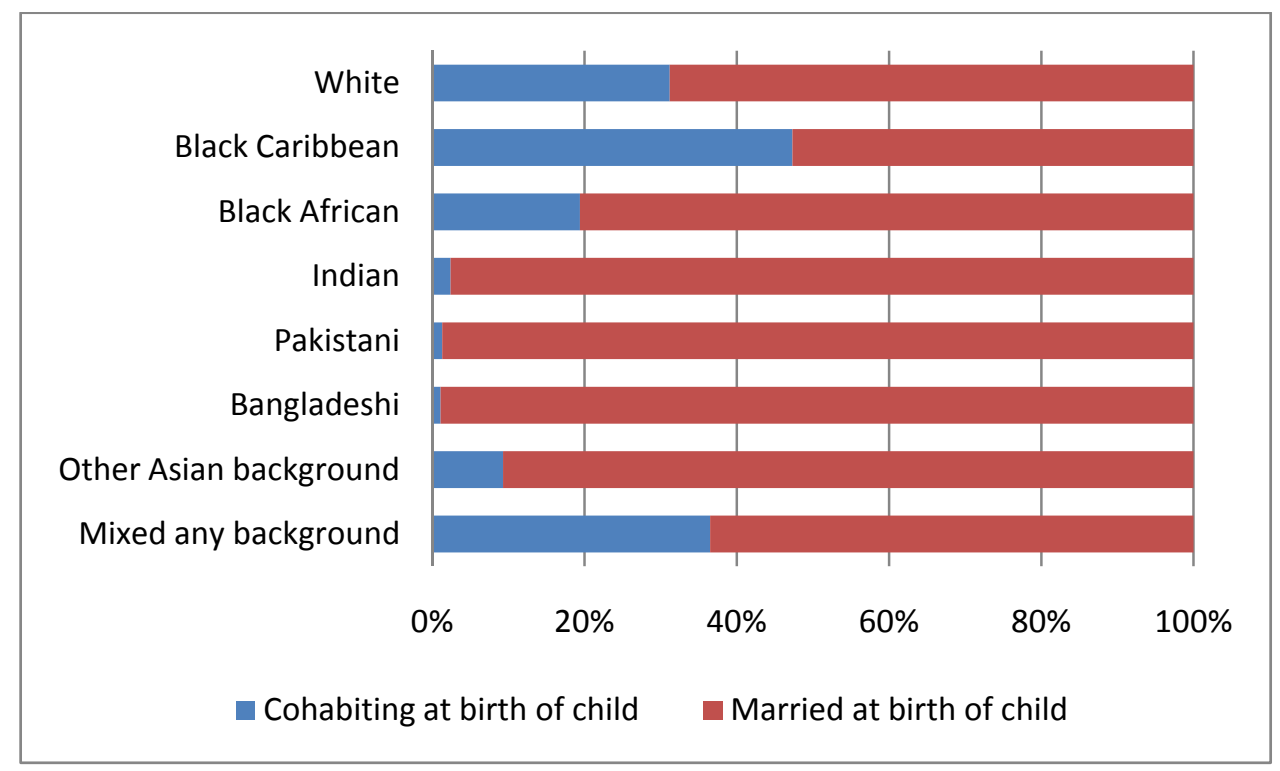

Note: The graph displays percentages weighted by the sample weights provided in the MCS data.

Figure 3 shows wider demographic characteristics for married and cohabiting couples. This and each subsequent graph in this section have a slightly different interpretation from Figure 2. Each bar represents the proportion of parents in married couples (in red) and cohabiting couples (in blue) that have that particular characteristic. For example, mothers in married couples are less likely to be White: $91 \%$ of mothers in married couples are White, compared with $97 \%$ of mothers in cohabiting couples. Similarly, mothers in married couples are more likely to have been born outside the UK. It is also more likely that the mother of married mothers (the grandmother of the child) was born outside the UK. Married mothers are less likely to have no religion at all; this partly reflects the fact that ethnic minorities that are more likely to be religious are more likely to get married (see Figure 2). As religion, ethnicity and immigration status are important predictors of educational attainment, it is important to control for these variables in later analysis.

\section{Figure 3. Who marries and who cohabits? Mother's background and religion}

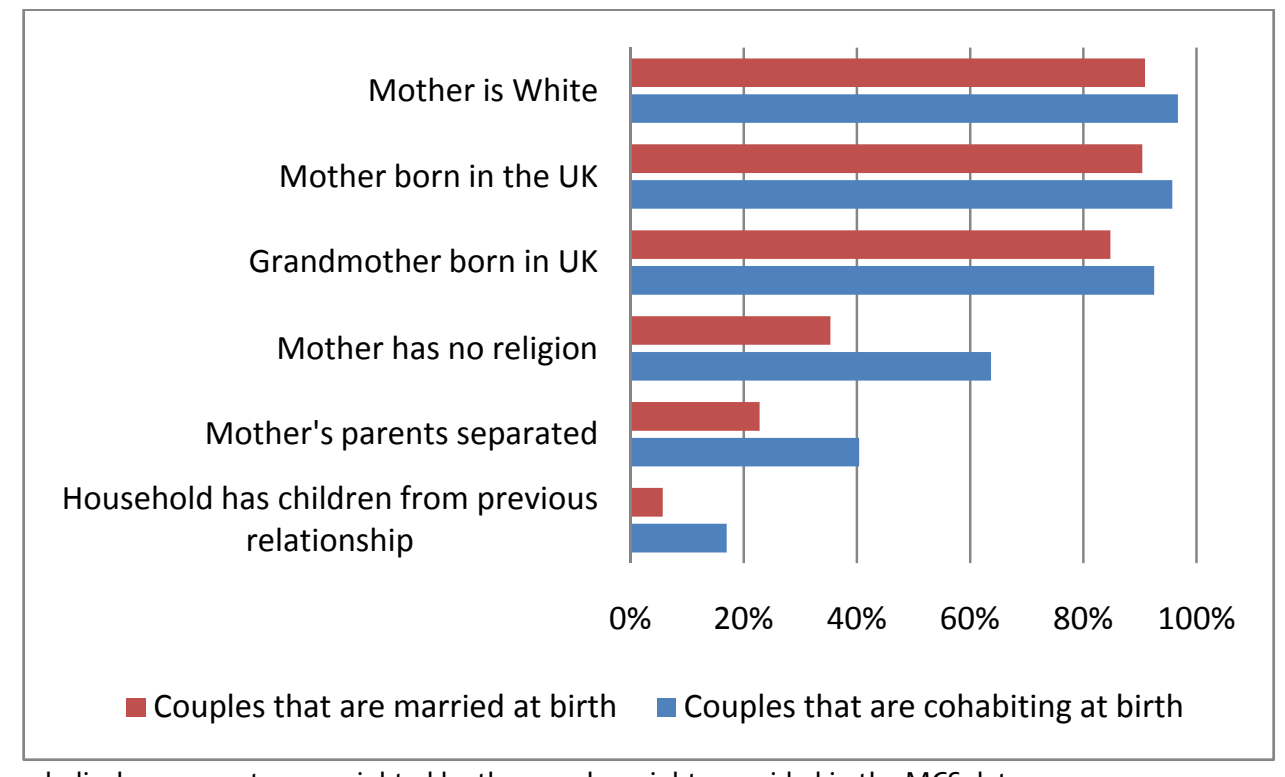

Note: The graph displays percentages weighted by the sample weights provided in the MCS data. 
There are also differences in other background characteristics between mothers who are married and mothers who are cohabiting when their child is born. Around $40 \%$ of mothers who are cohabiting when their child is born experienced their own parents' separation, compared with $23 \%$ of mothers who are married when their child is born. Mothers in married couples are also less likely to have children from a previous relationship; we proxy this by looking at the percentage of families in which the child in the MCS survey has at least one half- or step-sibling in the household. This is true in $17 \%$ of households where the couple is cohabiting, compared with $6 \%$ of households where the couple is married. These aspects of the mother's background reflect characteristics that existed prior to her current relationship and so will reflect the selection of individuals into marriage or cohabitation.

\subsection{Who marries and who cohabits? Characteristics mainly reflecting selection, but potentially capturing causal pathways (Group 2)}

Figure 4 shows the level of education of married and cohabiting parents (again, the characteristics of mothers and fathers in cohabiting couples are shown in blue, while the characteristics of mothers and fathers in married couples are shown in red). Both mothers and fathers in married couples are over twice as likely to have a degree as their counterparts in cohabiting couples. Married mothers are also slightly less likely to have problems reading in day-to-day life. Education appears to be largely predetermined before the decision to marry; for example, 99\% of mothers had left full-time education before they gave birth to their first child, and $98 \%$ of mothers who are married at the time of their child's birth had left full-time education before they got married. As the level of education is a choice that the individuals make, however, it is still possible that marriage partly affects it - it is possible that marriage fosters investment in education or training, for example. This discussion suggests that differences between married and cohabiting couples in their education might both reflect selection into marriage and be caused in some part by marriage itself.

Figure 4. Who marries and who cohabits? Parents' educational qualifications

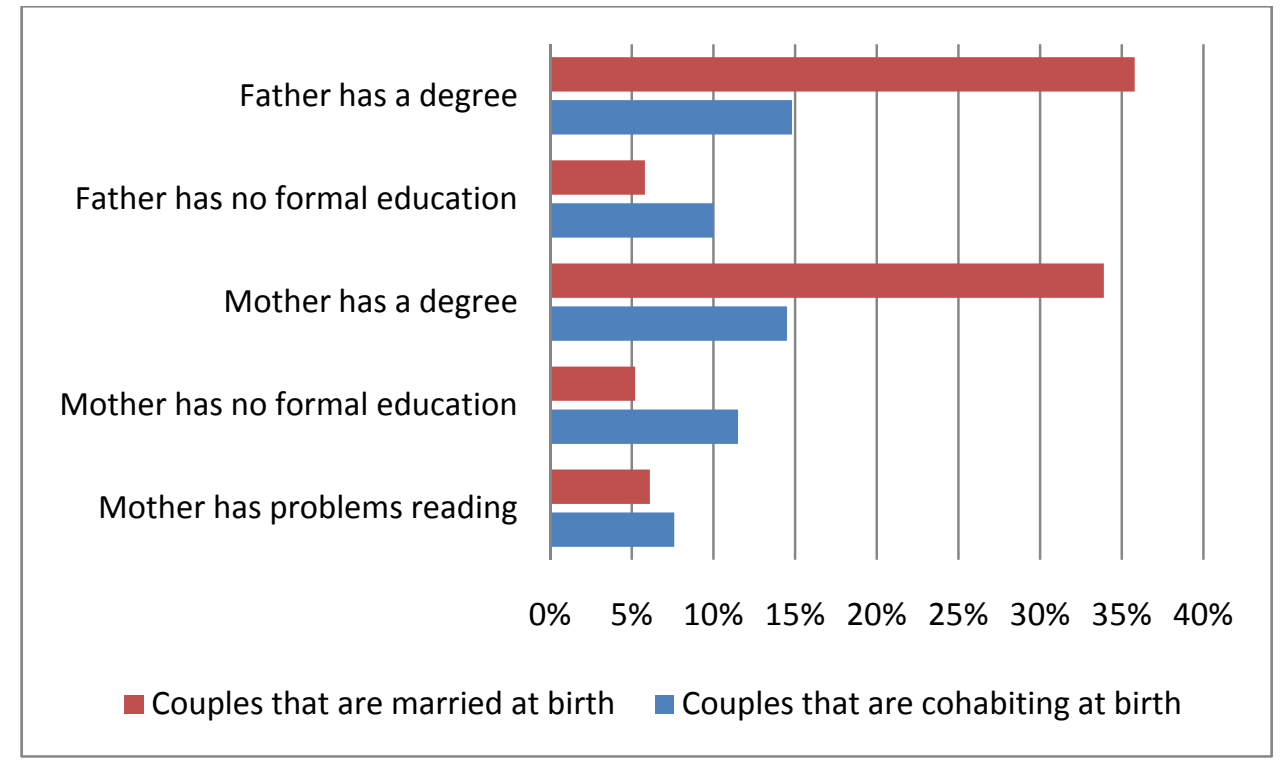

Note: The graph displays percentages weighted by the sample weights provided in the MCS data. 
Figure 5 shows the occupation (of the father), and the couple's income and housing tenure at the earliest point we observe them (when the child is 9 months old). Married fathers are twice as likely to have a professional occupation as cohabiting fathers, while couples that are married at the time of their child's birth are twice as likely to be in the highest household income quintile and a third as likely to be in the lowest household income quintile. This may be mostly due to selection (that is, couples that are better off are more likely to get married), but it could also be the case that individuals' wages might be improved by marriage itself - for example, if any additional expectation of stability brought about by marriage improved the effectiveness of the division of labour between partners. ${ }^{21}$

\section{Figure 5. Who marries and who cohabits? Occupation, income and housing tenure when the child is 9 months old}

Father has professional occupation

Father has routine occupation

Highest income quintile

Lowest income quintile

Own/mortgage house

Rent from Local Authority

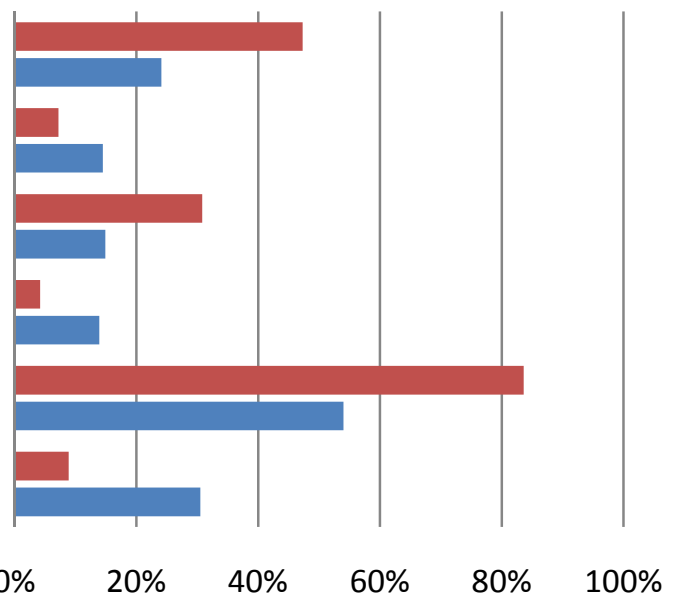

Couples that are married at birth Couples that are cohabiting at birth

Note: The graph displays percentages weighted by the sample weights provided in the MCS data.

Married couples are much more likely to own or have a mortgage for their home: $84 \%$ of married couples are in this position, compared with $54 \%$ of cohabiting couples. Do the higher rates of home ownership for couples that are married at the time of the birth reflect the selection issue? We believe that, as a proxy for wealth, home ownership largely reflects predetermined characteristics of the parents, and is therefore illustrative of the characteristics of parents who select into marriage. The decision to buy a home is a big commitment, however, and could be affected by the expectation of the relationship's stability. This expectation will depend to a large extent on the pre-existing level of a couple's commitment to each other, but may also be increased by marriage. Through this indirect channel, marriage may influence the household wealth of the family (which may have an impact on the child's development) or may provide a nourishing environment for the child's development in other ways.

Thus we cannot conclude that the characteristics shown in Figure 5 are entirely unaffected by the decision to marry, but we believe that they are largely predetermined. We therefore include these variables in our later analysis of the selection issue, but are more cautious in our interpretation of their impact.

\footnotetext{
${ }^{21}$ There is an extensive economics literature that tries to explain the so-called 'marriage premium' in men's wages. For example, Bardasi and Taylor (2008) find a positive impact of marriage on men's wages compared with single counterparts, which they attribute largely to specialisation in the household. Most of the existing literature on this topic suggests that any true marriage premium (that takes account of differential selection into marriage) is likely to be small, and possibly non-existent between married and cohabiting couples. Stratton (2002) studies the wage premiums for married and cohabiting men (compared with single men) in detail, concluding that partnership brings a larger premium for married men, controlling for background characteristics. The difference between married and cohabiting men is not statistically significant once the length of the relationship is controlled for, however.
} 
Figure 6 shows differences between cohabiting and married couples in some other characteristics of the family. These include measures related to the child in the MCS - for example, whether the pregnancy was planned, whether the child is the oldest sibling, the parents' relationship duration prior to the birth and the frequency of contact with grandparents. We also include the mother's age when she first gave birth (which may or may not have been the child followed by the MCS survey). The graph shows that mothers in cohabiting couples are much more likely to have been a teenager at the time of their first child's birth: $18 \%$ of mothers in cohabiting couples first gave birth when they were under the age of 20, compared with $4.2 \%$ of married mothers, while over $30 \%$ of married mothers were over 30 at the time of their first child's birth. This is likely to reflect the different background of mothers in cohabiting relationships, since teenage motherhood is much more common among women from low socio-economic status backgrounds. ${ }^{22}$ Teen motherhood also generally occurs prior to marriage: $93 \%$ of those in our sample who choose to get married are over 20 . In these cases, teen motherhood cannot have been affected by the decision to marry, and so largely reflects the selection of couples into marriage.

\section{Figure 6. Who marries and who cohabits? Family structure and age of the parents at birth of their first child}

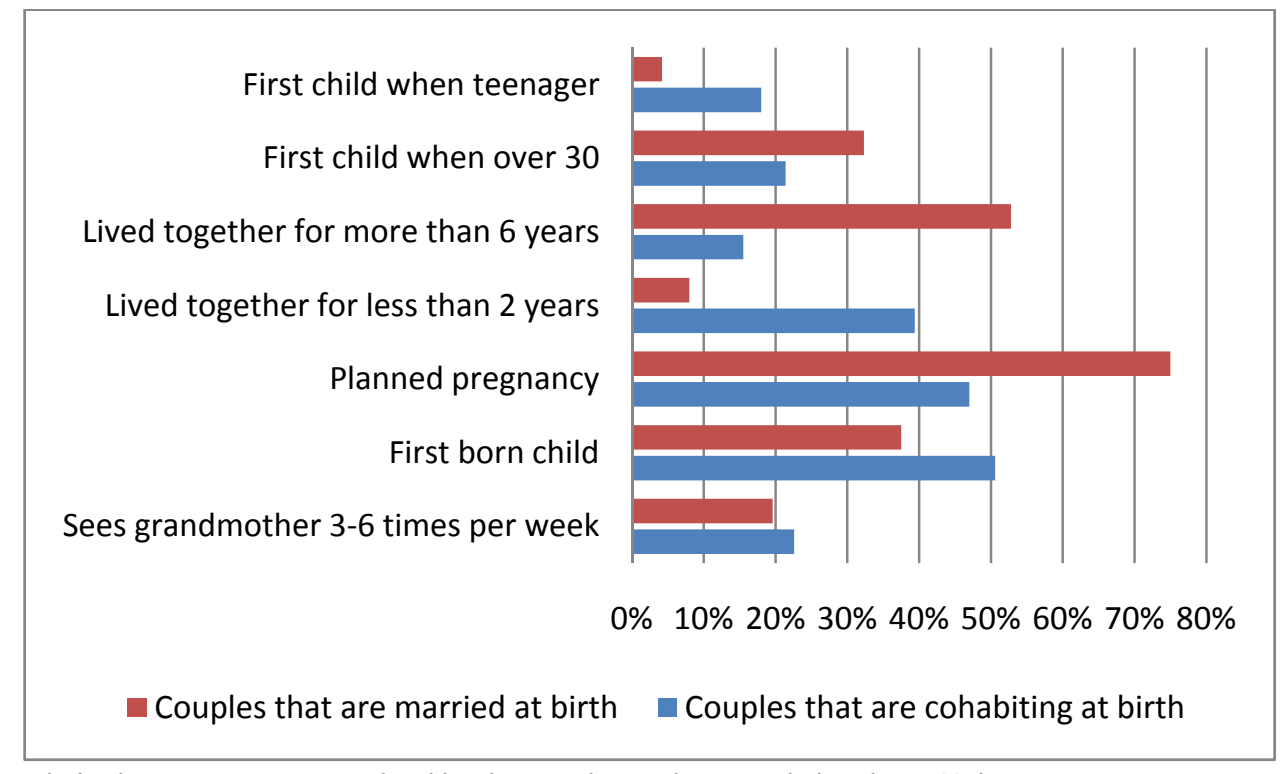

Note: The graph displays percentages weighted by the sample weights provided in the MCS data.

Figure 6 also shows that married couples are much more likely to have lived together for a longer period of time prior to their child's birth than cohabiting couples: over half of married couples have lived together for more than 6 years before the birth of the child in the MCS, compared with 16\% of cohabiting couples, and almost $40 \%$ of cohabiting couples had lived together for less than 2 years, compared with only $8 \%$ of married couples. ${ }^{23}$ The length of time the couple has lived together probably reflects the fact that it is more stable, longer-lasting, couples that choose to marry. It could also be argued, however, that the act of getting married itself causes additional stability within the relationship. Our study cannot discern which of these two interpretations is the more important.

Mothers in married couples are also much more likely to report that their pregnancy was planned: this was the case for $75 \%$ of married mothers compared with $47 \%$ of cohabiting mothers. What does this tell

\footnotetext{
${ }^{22}$ See, for example, Goodman, Kaplan and Walker (2004).

${ }^{23}$ Large differences between married and cohabiting couples remain if we only look at couples for which the child in the MCS survey is the oldest child in the household: $24 \%$ of married couples have lived together for longer than 6 years prior to the birth, compared with $6 \%$ of cohabiting couples. Over half of cohabiting couples have lived together for less than 2 years, compared with $15 \%$ of married couples.
} 
us about the types of women who select into marriage? Unplanned pregnancies are more prevalent among mothers with low socio-economic status and their incidence also varies by mother's age and ethnicity. ${ }^{24}$ It may also reflect the underlying relationship quality or the degree of impulsivity of the couple. It is our judgement that differences in the incidence of unplanned pregnancies between married and cohabiting couples largely reflect the different sorts of couples that decide get married (i.e. selection). As these attributes of the parent are also likely to have an impact on children's outcomes, it is important to control for them in later analysis. We recognise that there is an alternative interpretation of this characteristic, however, as whether a pregnancy is planned may be affected by the decision to get married. If mothers in a married couple feel more secure, for example, this may lead them to be more ready to have a child. Along with the other variables included in Group 2, we use the characteristics in Figure 6 primarily to assess the selection issue, but we are aware that they could also be partially caused by cohabitation or marriage itself.

\section{Figure 7. Who marries and who cohabits? Relationship quality when the child is 9 months old}

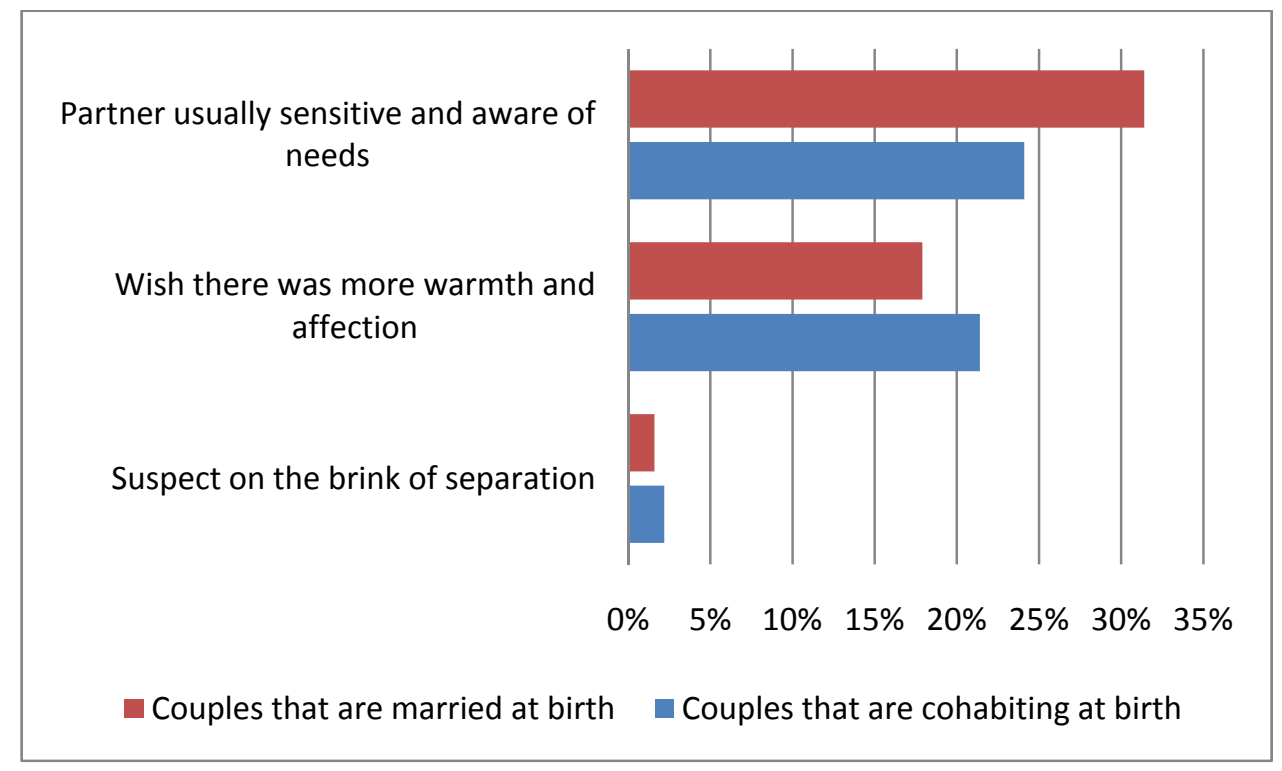

Note: The graph displays percentages weighted by the sample weights provided in the MCS data.

Figure 7 suggests that there is some difference in 'early' relationship quality between married and cohabiting couples. For example, when the child is 9 months old, $31 \%$ of married mothers report that their partner is usually sensitive and aware of their needs, compared with $24 \%$ of cohabiting mothers. There is a smaller difference in the percentage of married and cohabiting mothers who wish there was more warmth and affection in their relationship, however, or who suspect that they are on the brink of separation. The responses to these and other related questions have been grouped together to form a relationship quality index (at 9 months), in which married couples score significantly higher than cohabiting couples. We include this relationship quality at 9 months index within our group of variables that are likely both to reflect selection into marriage and to be affected by marriage (Group 2). This is because individuals are very likely to take the underlying quality of the relationship into consideration when deciding whether or not to get married. On the other hand, the greater permanence associated with marriage could also positively foster relationship quality. We believe that we are more likely to capture the underlying relationship quality in this 'early' measure (as opposed to measures of relationship quality when the child is older, and the couple have been together for longer). The interpretation of relationship

\footnotetext{
${ }^{24}$ See Baydar (1995).
} 
quality early in the child's life is perhaps the most debatable parental characteristic that we include in the Group 2 set of variables. However, for relationship quality to act as a causal pathway between parents' formal marital status and children's development, it would need to be established that marriage leads to significant improvements in relationship quality by the time the child is 9 months old, which in turn lead to better outcomes for children. This cannot be ascertained from our study.

\subsection{Who marries and who cohabits? Characteristics that are possible causal pathways (Group 3)}

We now look at characteristics of the parents that we think of as possible causal pathways in explaining the differences in cognitive and behavioural outcomes between children of married and cohabiting couples.

Figure 8 shows that cohabiting couples are considerably more likely to experience a period of separation of a month or longer before their child is 3 years old; this is the case for $26 \%$ of cohabiting couples and $7 \%$ of married couples. Couples that are cohabiting at the time of their child's birth, rather than being married, are also less likely to live together when their child is aged 3. This large difference in relationship stability and breakdown has been attributed as being a large cause of the gap in attainment between children of married and cohabiting couples. ${ }^{25}$

Figure 8 . Who marries and who cohabits? Relationship stability and quality at age 3

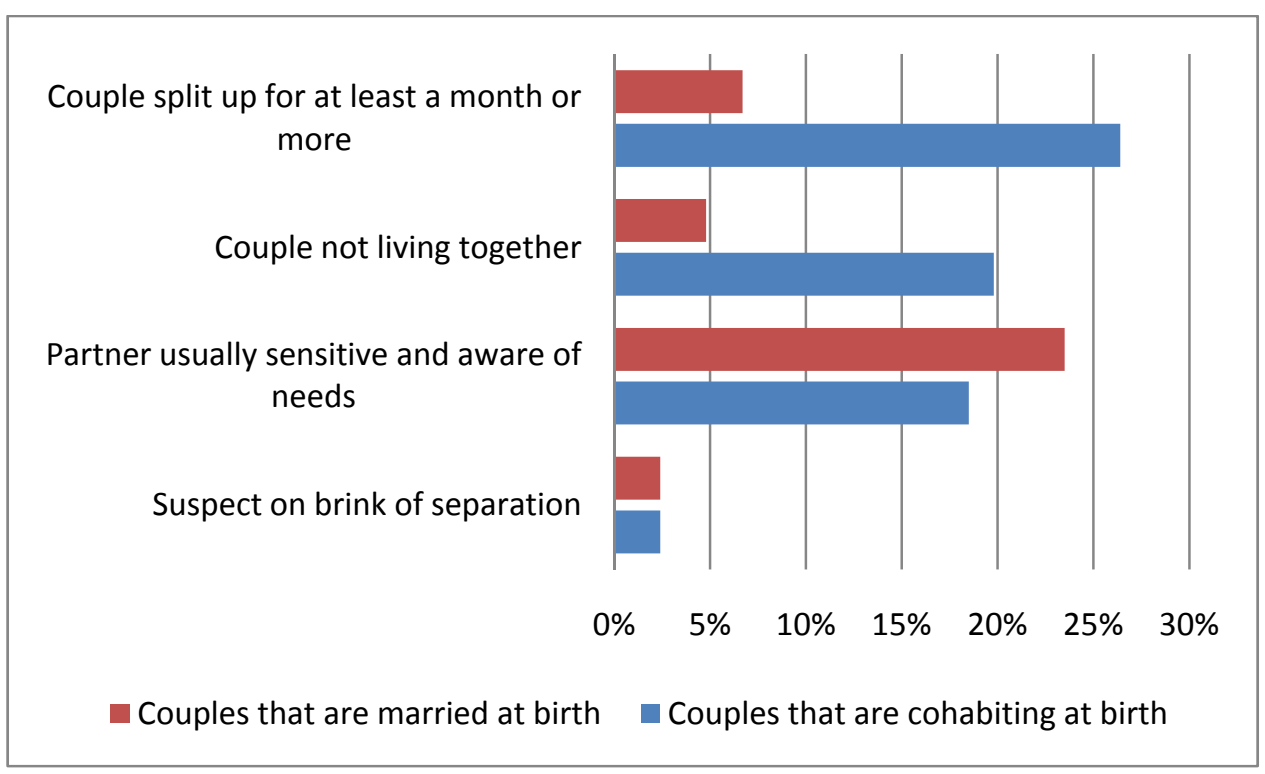

Note: The graph displays percentages weighted by the sample weights provided in the MCS data.

The observation that married couples have fewer periods of separation does not in itself tell us whether this is due to the selection of parents into marriage or is a causal effect of marriage. This is because couples that choose to get married may be more committed (in a way that is unobservable to us). This may drive, at least in part, the fact that married couples experience fewer periods of separation after their child's birth. Alternatively, marriage might also reduce the likelihood of periods of lone parenthood through social and cultural norms and expectations, or through the legal barriers around separation that were discussed in Chapter 2.

\footnotetext{
${ }^{25}$ Manning, Smock and Majumdar, 2004.
} 
Figure 8 also shows indicators for self-reported relationship quality when the child is aged 3 . There is no difference in the percentages of couples that report that they suspect they are on the brink of separation, although they may have already separated. There is a difference in the percentages of mothers who think their partner is usually sensitive and aware of their needs; this is true for $24 \%$ of married couples and $19 \%$ of cohabiting couples (slightly lower than reported when the child was 9 months old).

Relationship breakdown often leads to significant changes in the income and work patterns of the individuals involved. We therefore consider whether changes to parental labour supply and income between when the child is 9 months old and the ages of 3 and 5 might be important causal pathways between marriage and child outcomes. Figure 9 shows the work status and income of the household when the child in the MCS is 3 years old, and shows that married mothers are slightly more likely than cohabiting mothers to be in work when their child is aged 3. Couples that are cohabiting at birth seem to have more fluctuations in their household income: $19 \%$ experience an increase in income large enough to move up at least one income quintile, compared with $15 \%$ of married couples. The proportion of couples whose income falls over the period is also slightly higher among cohabiting couples than among married couples. However, while household income differs starkly between married and cohabiting couples when their child is 9 months old (shown in Figure 5), married couples experience no overall relative increase in income compared with cohabiting couples in the time before their child is 3 years old.

Figure 9. Who marries and who cohabits? Income and work status of the household at age 3

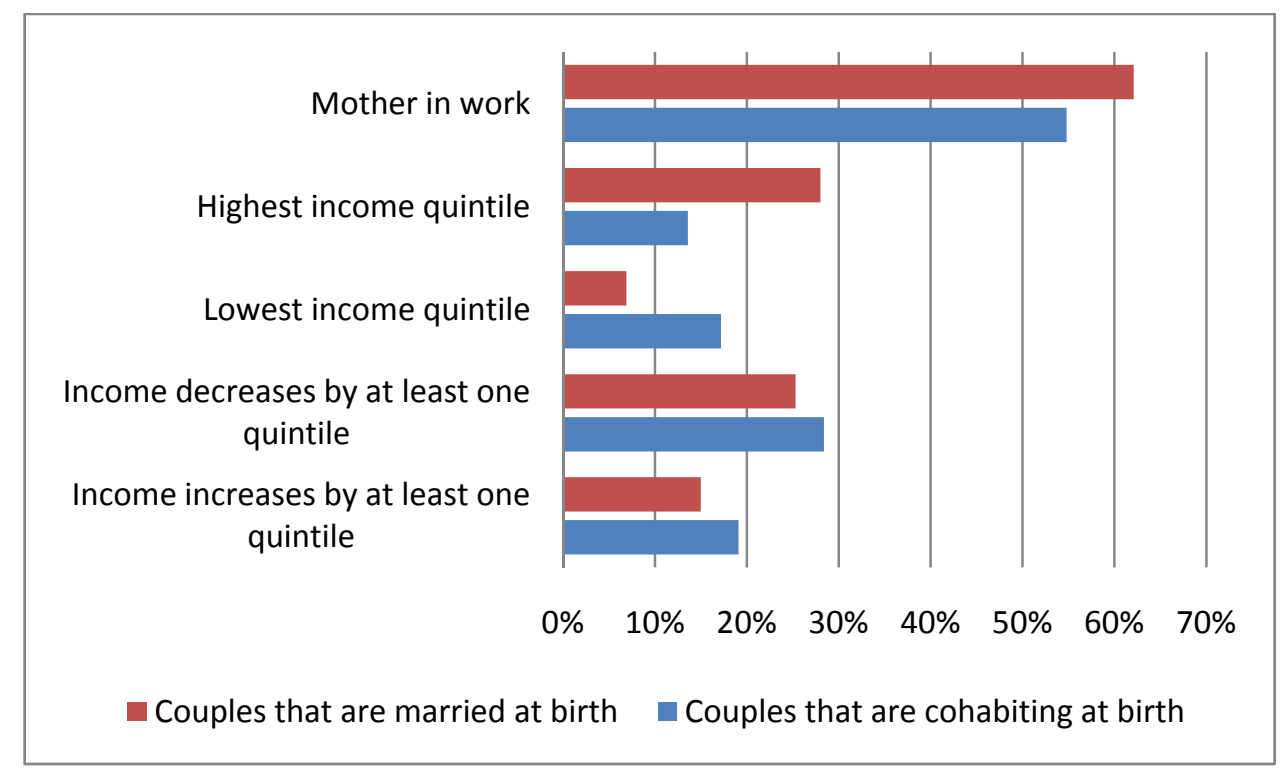

Note: The graph displays percentages weighted by the sample weights provided in the MCS data.

Figure 10 shows that mothers who are married when their child is born and their child have slightly better health outcomes than mothers who are cohabiting. The child is slightly less likely to have a low birthweight (5.8\% of children born to married couples, compared with $7.4 \%$ born to cohabiting couples) and slightly less likely to have been born prematurely (7.7\% compared with $8.5 \%)$. These differences may indicate more stress or less support in the relationship for cohabiting couples, ${ }^{26}$ but again may be partly determined by pre-existing characteristics of the parents - for example, education and income.

\footnotetext{
${ }^{26}$ Rondo et al., 2003.
} 
Figure 10. Who marries and who cohabits? Health and health-related behaviours

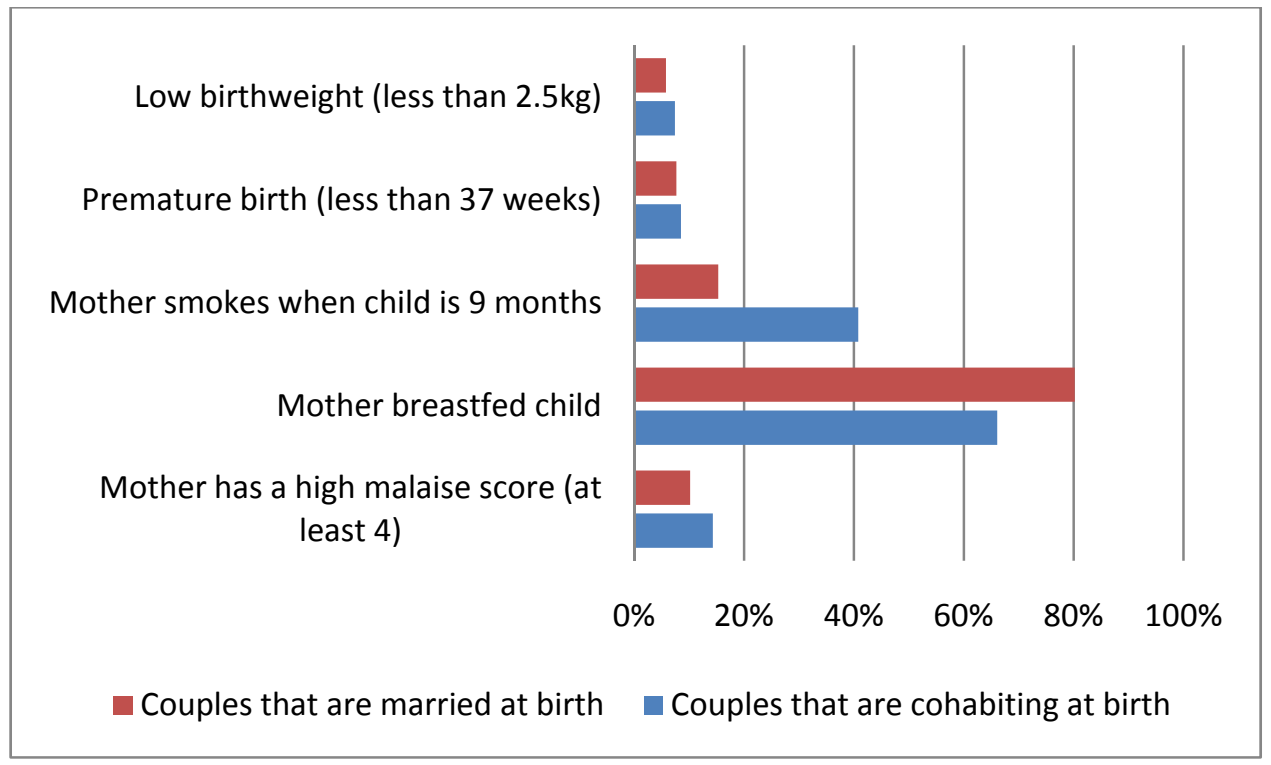

Note: The graph displays percentages weighted by the sample weights provided in the MCS data.

Figure 11. Who marries and who cohabits? Parenting practices and belief in parenting ability at age 3

Father's involvement is in the lowest
quintile at 9 months
Home learning environment in the
lowest quintile
Mother thinks good or very good
parent

Father thinks good or very good parent

Child has regular bedtime

Child is read to daily

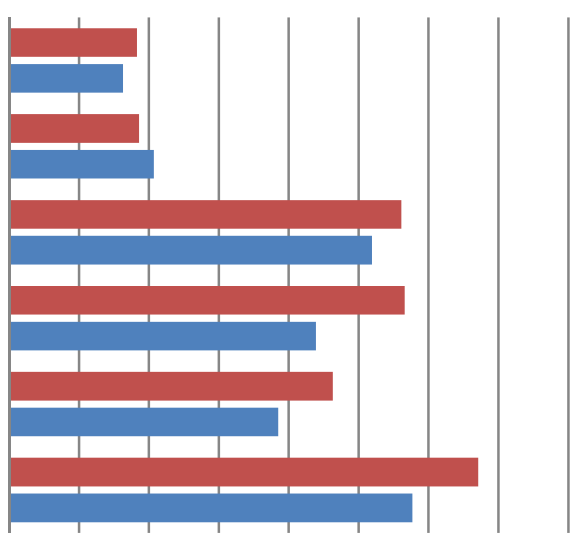

0\% $10 \%$ 20\% 30\% 40\% 50\% 60\% 70\% $80 \%$

Couples that are married at birth Couples that are cohabiting at birth

Note: The graph displays percentages weighted by the sample weights provided in the MCS data.

Mothers in cohabiting couples when their child is born are much more likely to smoke when the child is 9 months old: $41 \%$ of mothers in cohabiting couples smoke, compared with $15 \%$ of mothers in married couples. Mothers in cohabiting couples are also less likely to breastfeed their child at all, and slightly more likely to have a high score on an index of 'mother's malaise' when the child is 9 months old, which is indicative of depression. Although these health outcomes may be caused by differences in marital status, it is likely that they also indicate pre-existing characteristics of the parent to some extent.

Figure 11 shows various measures of parents' encouragement of and investment in their child's development and learning. Fathers in married couples are slightly more likely to have the lowest level of involvement with their child at 9 months old, but are more likely to rate themselves as 'good' or 'very good' parents when their child is aged 3: $57 \%$ of fathers in married couples have this belief, compared 
with $44 \%$ of fathers in cohabiting couples. There is less difference in the percentage of mothers in each household type who believe they are 'good' or 'very good' parents. Couples that are married at the time of the birth are more likely to have a more regular routine for their child: $46 \%$ have a regular bedtime for the child at age 3, compared with $39 \%$ of cohabiting couples, which may indicate greater stability in the household. Married couples seem to provide slightly richer home learning environments at age 3:67\% read to their child daily, compared with $58 \%$ of cohabiting couples. The 'home learning environment' variable is a scale constructed from various measures of the home life of the child, such as the frequency of visits to the library and other outings, and whether the parents sing or do crafts with the child. Parents who are married at birth are slightly less likely to be in the lowest quintile of the home learning environment index, although the difference is small (19\% compared with 21\%). These characteristics may be affected by the parents' marital status if marriage leads to less parental stress and a more supportive home environment. Again, we cannot assess to what extent these characteristics or tendencies of the parents already existed before the couple decided whether or not to get married, or how much they are affected by marriage itself. 


\section{What are the outcomes of children born into married and cohabiting families, at ages 3 and 5 ?}

In this section, we compare the differences in child outcomes between children born to married and cohabiting couples. We then go on in Chapter 6 to assess the extent to which differences in the characteristics of married and cohabiting parents that we discussed extensively in Chapter 4 can account for such differences in child development.

By the age of 3, there are significant differences in child outcomes between children born to married parents and those born to cohabiting parents. On average, children born to married parents display better social and emotional development (as measured by the Strengths and Difficulties Questionnaire, SDQ) and stronger cognitive development (here captured by the British Ability Scales (BAS) vocabulary element) compared with children born to cohabiting parents.

Figure 12 shows the development of children born to married and cohabiting couples, relative to the whole population of children in the MCS. As the measures of cognitive and social and emotional development have been standardised to have a mean of 0 and a standard deviation of 1 , the horizontal line at 0 represents the average level of development for all children with all assessments available. The graph shows that children born to cohabiting couples have a level of cognitive development of about average at age 3 . Children born to married couples have a level of cognitive development about a tenth of a standard deviation above average at age 3 . This means that at age 3 , there is a gap between children born to married and cohabiting couples of around $1 / 10$ standard deviation.

Figure 12. Cognitive development (BAS) and social and emotional development (SDQ), for children born to married and cohabiting couples, at ages 3 and 5

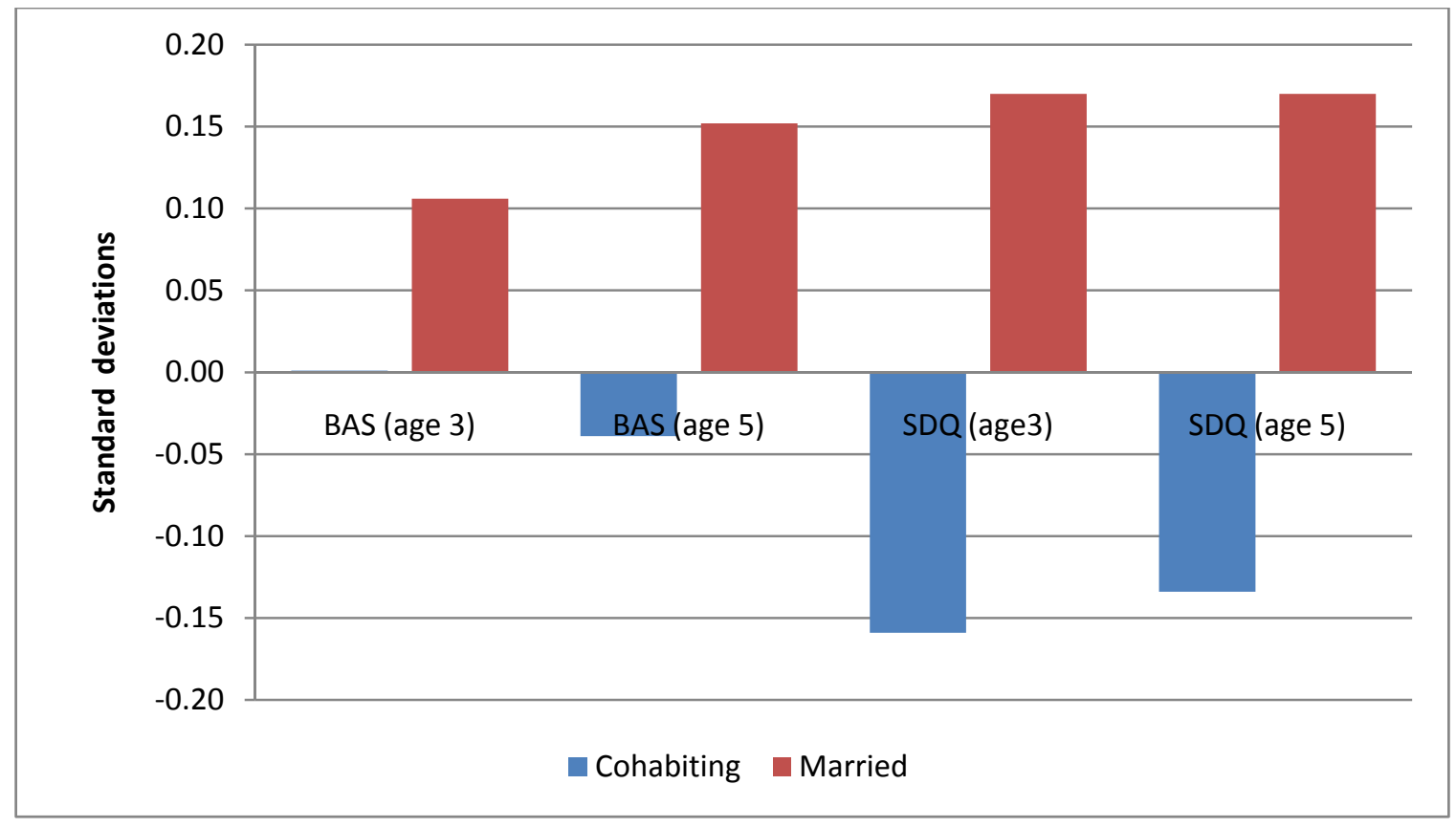

There is a larger difference between children born to married and cohabiting parents in terms of their social and emotional development. Figure 12 shows that children born to married parents score around 
$1 / 6$ standard deviation above the average score in the population at age 3 , while children born to cohabiting parents score around $1 / 6$ standard deviation below the average. ${ }^{27}$ This implies a gap in development between children born to married and cohabiting couples of around $1 / 3$ standard deviation.

How do these gaps change over time? The gap in cognitive development is slightly larger when the children are 5 years old, as children of married couples score slightly higher above the average child in the population while children born to cohabiting couples score slightly lower. By the age of 5 , the gap between children born to married and cohabiting children in social and emotional development remains about the same.

While much of the current UK policy debate revolves around whether or not couples should be encouraged to marry before they have children, many argue that it is the family environment experienced within the earliest years of life, rather than just at birth, which is the most relevant for determining children's early outcomes.

Figure 13. Differences in social and emotional development (SDQ), and cognitive development (BAS) between children born to married compared to cohabiting couples, at ages 3 and 5

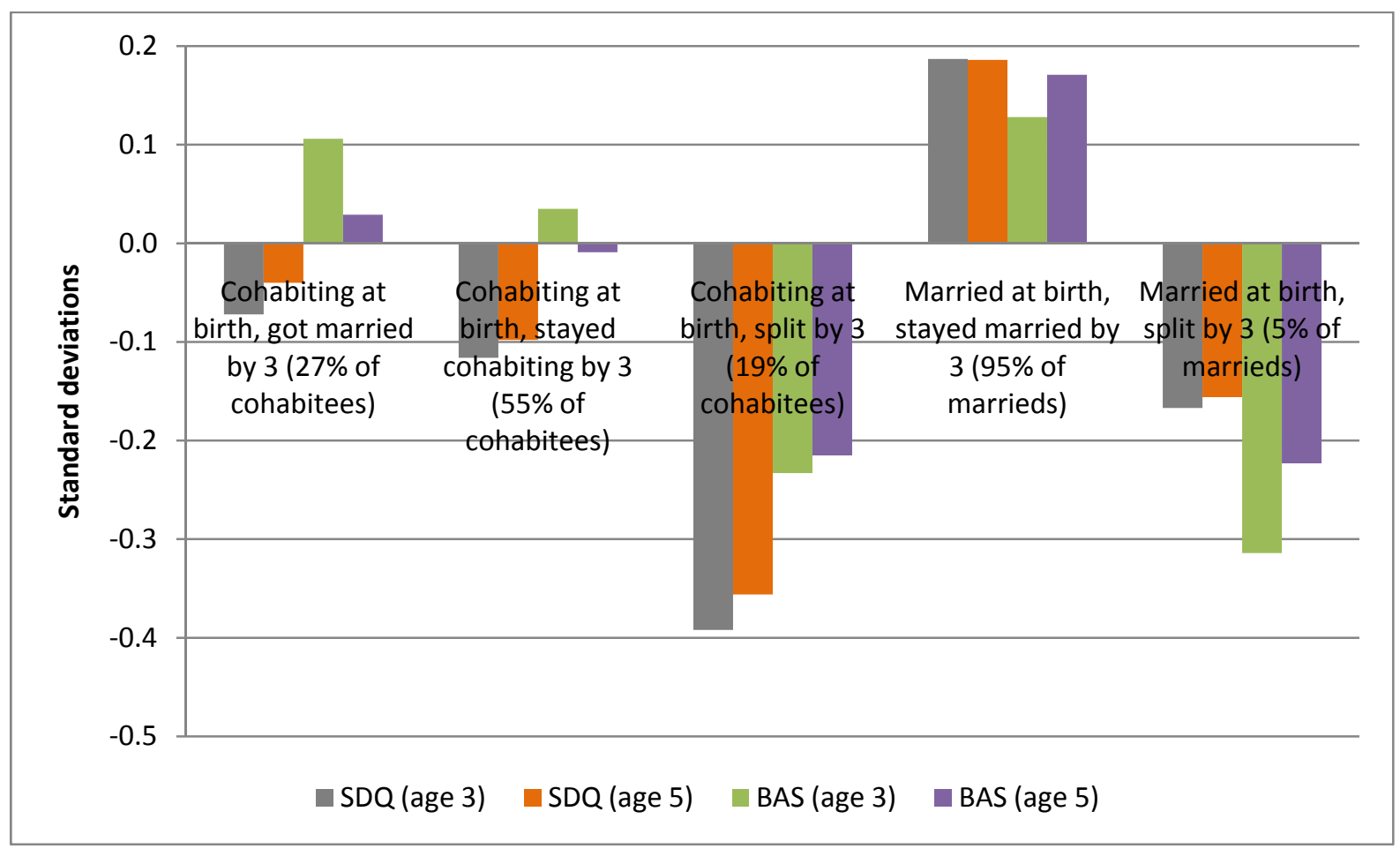

\footnotetext{
${ }^{27}$ Note that the scores are standardised across the full population of children in our sample, and so the average scores with which those of children born to married and cohabiting couples are compared include those of children born into lone-parent families and other family forms.
} 
Figure 13 thus divides children whose parents were cohabiting at the time of the birth into whether these cohabiting biological parents have, by the time the child is 3 , (i) got married, (ii) remained cohabiting or (iii) split up. Similarly, it divides children born to married parents into those whose biological parents, by the age of 3, (i) remain married or (ii) split up. One important point to note from this graph (as shown in the percentages provided in the $\mathrm{x}$-axis labels) is that while a significant proportion of cohabiting couples decide to get married, the likelihood of the relationship breaking down by the age of 3 among cohabiting couples is also high. In particular, relationship break-up rates are much higher among cohabiting couples than among married couples.

Figure 13 shows clearly that the most negative outcomes for children on average are amongst those whose biological parents have split up, regardless of the formal marital status of the parents when the child was born.

These graphs do not imply any causal association between cohabitation and relationship breakdown, nor indeed between parental break-up and child outcomes, but they do suggest that further investigation of the role of relationship instability in driving the observed outcome gaps between children born into cohabiting compared with married relationships is warranted (we return to this in Chapter 6).

Finally, we consider how big the outcome gaps between children born into married compared with cohabiting families are in a wider context. Figure 14 highlights the fact that the outcome gaps in cognitive development between children born to married and cohabiting parents are relatively small compared with the outcome gaps associated with, for example, (i) being born into a lone-parent family compared with any couple; (ii) low versus high income (and other socio-economic differences) and (iii) ethnic group. Figure 15 illustrates that this is also the case for social and emotional development at age 3.

Figure 14. Differences in cognitive development between children of married and cohabiting couples in context (age 3)

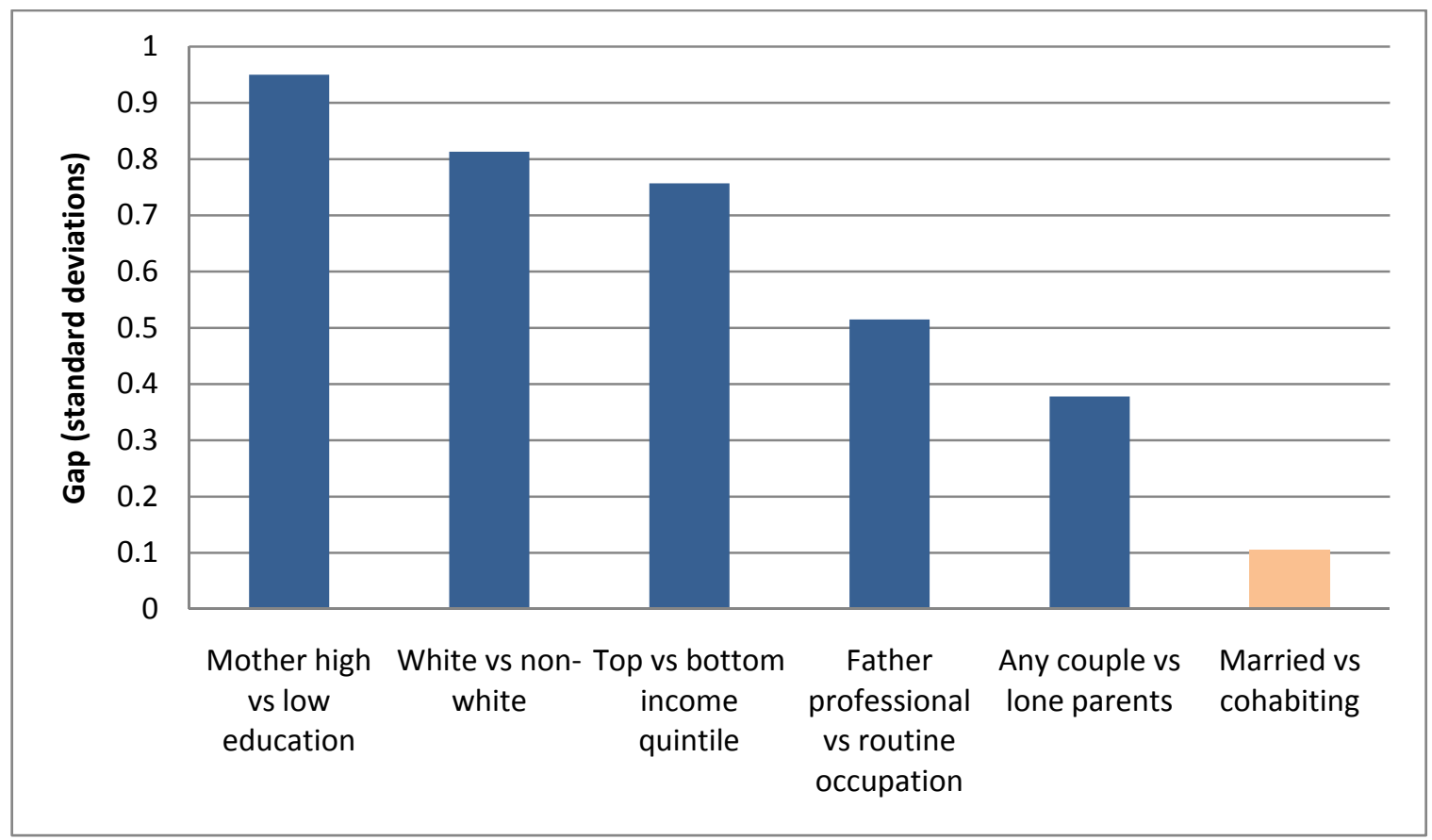


Figure 15. Differences in social and emotional development between children of married and cohabiting couples in context (age 3)

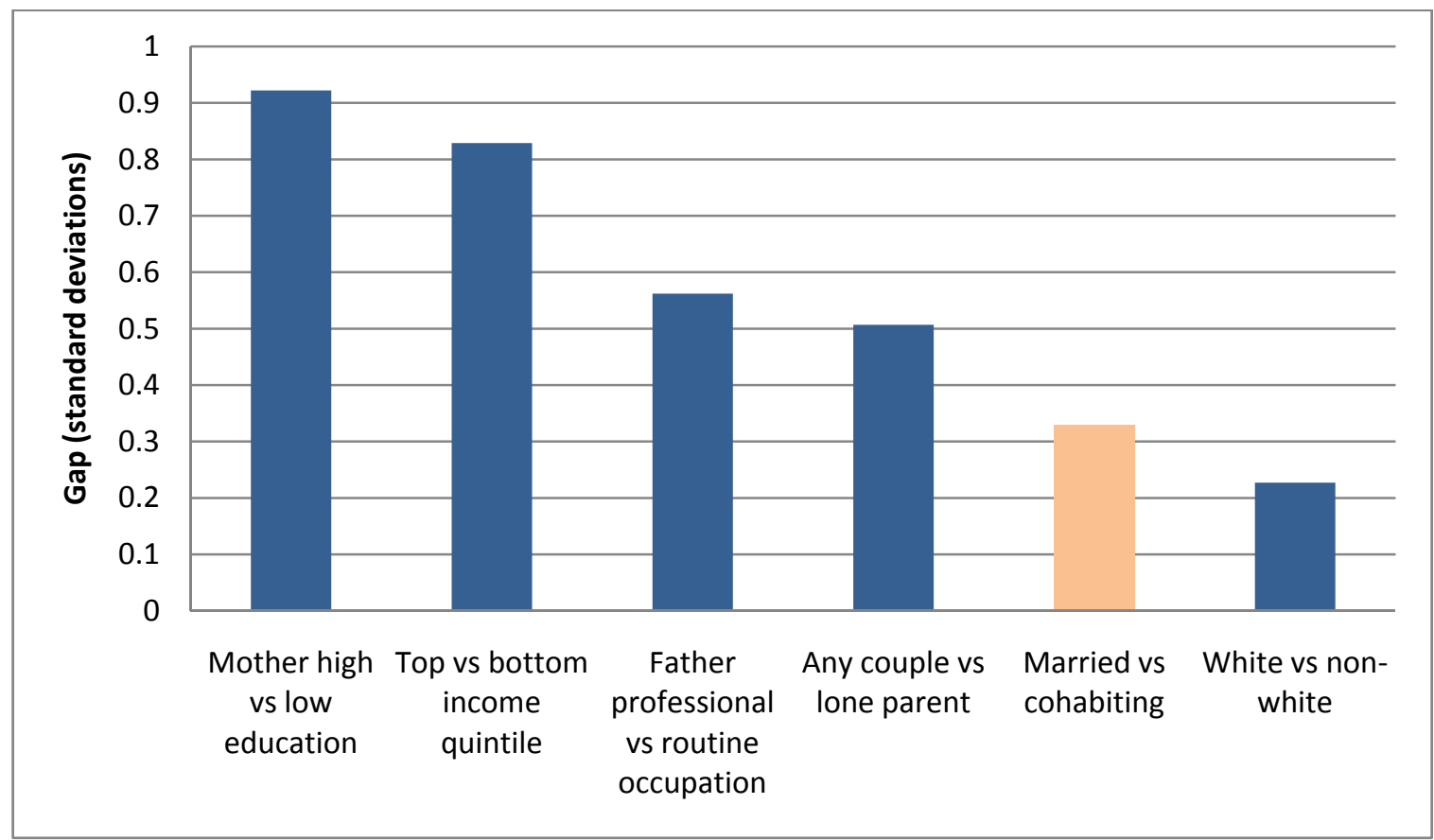




\section{What are the outcomes of children born to cohabiting compared with married parents, after controlling for observable differences?}

In this section, we show how controlling for the observable characteristics described in Chapter 4 affects our estimates of the differences in cognitive and social and emotional outcomes between children born to married parents and children born to cohabiting parents. Our intention in controlling for these observable characteristics is twofold:

- Where these characteristics purely reflect the type of people who decide to cohabit, rather than to get married, controlling for them helps us to partially deal with the selection issue that we discussed in some detail in Chapter 2.

- Where these characteristics are ones that might be altered by being married, or cohabiting, then controlling for them helps us understand the extent to which they are the causal pathways through which cohabiting might lead to different outcomes for children, compared with being married. (Again, we discussed some theories behind what these causal pathways might be in Chapter 2.)

The problem that we face in trying to divide the observable characteristics of parents into either of the two functions that we set out above is that only a few of them fall cleanly into one camp or the other. This is because almost all of them are likely both to reflect the sort of people who select into marriage and to be partly determined by the presence or absence of marriage in itself.

As already discussed in Chapter 4, we therefore classify our control variables into three different groups:

- Group 1 - ones that are fixed over time, and so are unlikely to be affected by marriage;

- Group 2 - ones that mainly reflect selection, but potentially capture causal pathways;

- Group 3 - ones that are possible causal pathways.

All our regression tables are shaded accordingly, to reflect these three different groupings of our controls.

Our argument is that controlling for variables in Groups 1 and 2 will mainly help us deal with the selection issue - namely, that different sorts of people decide to cohabit rather than to marry. In doing this, however, we are aware that we may also inadvertently control away some of the indirect effects of marriage (as we discussed in Chapter 2).

Our intention in controlling for variables in Group 3 is mainly to investigate empirically the causal pathways through which cohabitation or marriage might have positive or negative effects. We are aware that our control variables contained in Groups 1 and 2 are not sufficient to deal with the selection issue fully, as there is still likely to be 'selection on unobservable characteristics' as well as characteristics that we see. As such, we are aware that once we add Group 3 variables to the model, this will not only test for causal pathways between parents' marital status and children's development, but may also control for differential selection into marriage.

The discussion above leads us to a rather more cautious interpretation of results than many policymakers and interested parties would probably desire; we fall short of estimating cleanly either any true causal effect of marriage versus cohabitation on child outcomes, or the causal pathways through which any such effect might operate. This is because we are keen not to over-interpret findings beyond that which the evidence rigorously allows. 


\subsection{Results: comparing outcomes of children born to cohabiting parents and children born to married parents}

In this section, we present results from a set of simple regressions (estimated using ordinary least squares, OLS) in which the outcome of interest is either the child's social and emotional development (as measured by the SDQ) or the child's cognitive development (as measured by the vocabulary element of the BAS), at the ages of 3 and 5 . All of our outcomes have been standardised, so that all the regression coefficients are expressed in standard deviations.

For simplicity, our analysis sample includes only children whose parents were in couples (either married or cohabiting) at the time of their birth (further details of our sample selection can be found in Chapter 3 ).

The main coefficients of interest within these regressions will be those on the indicator(s) of the child's parents' formal marital status. In our simplest regression specifications (shown in Table 5 at the end of this chapter), the indicator is just a dummy variable (1-0 indicator) for whether or not the parents were cohabiting at the time of the child's birth, with the base group for comparison therefore being children whose parents were married at the time of the birth. The coefficient on this dummy variable can be interpreted as the average difference in outcome associated with being born to cohabiting rather than married parents, after controlling for the other variables included in the model.

We also show results from a set of regressions in which we include a more detailed categorisation of couples' relationship status, taking into account the couple's formal status both at birth and when the child is aged 3. This analysis is summarised in Table 6 at the end of this chapter and is described more fully in Section 6.2 .

Tables 5 and 6 show only the estimated coefficients on the main variables of interest (i.e. the cohabiting dummy/dummies), from a series of regressions. Each row of the tables shows a different outcome (e.g. cognitive development at age 3 , social and emotional development at age 3), while each column shows results from different regression specifications, when additional control variables are gradually added into the model. (Appendix Tables A3 and A4 show the full regression results for outcomes at age 3, including the coefficient estimates on all the other variables contained in the models. Appendix Tables A5 and A6 show the equivalent regressions for outcomes at age 5.)

The first column in our tables of regression results (column A) is derived from a model in which the only controls besides the marital status indicator are for the child's gender and month of birth. These characteristics are randomly allocated between married and cohabiting parents, so this column shows our estimates of the 'raw' (uncontrolled) differences between children of cohabiting couples and children of married couples.

These gaps match very closely the outcome gaps between married and cohabiting parents that were graphed and described in some detail in Chapter 5. For example, column A of Table 5 shows that children born to cohabiting parents have lower test scores than those born to married parents (hence the negative sign on the coefficients). There is a gap of around 0.1 of a standard deviation in cognitive development at age 3 and a gap of 0.19 of a standard deviation at age 5 . The gaps in social and emotional development are somewhat larger, at around 0.33 of a standard deviation at age 3 and around 0.3 of a standard deviation at age 5 . These gaps are all statistically significant. As we noted in Chapter 5 , however, they are smaller than other commonly-cited gaps in cognitive and social and emotional development at these ages - for example, between children from rich and poor backgrounds. 


\section{Controlling for observable characteristics: those that probably largely reflect selection into marriage/cohabitation}

In columns B-G, we add the additional Group 1 and Group 2 characteristics to our model, which we argued in Chapter 4 largely reflect differences in selection into marriage. The main aim behind this exercise is therefore to assess the extent to which selection accounts for the outcome gaps between children born to cohabiting and married couples. We acknowledge that some of these variables might also be affected by the decision to marry itself, however, and so we risk the possibility of controlling away some (potentially positive) effects of marriage in undertaking this exercise. Perhaps the most debatable of those that we have included is early relationship quality (at 9 months), which is entered singly in column G. We must also be cautious in the interpretation of the effect of housing tenure, which we believe largely reflects a couple's pre-existing level of wealth and perhaps degree of commitment, but could also be affected by marital status.

Turning now to our results, column B comes from a model that contains mother's ethnicity, immigration status and religion as additional controls. Table 5 shows that after controlling for these variables, the gaps in cognitive development between children born to cohabiting couples and children born to married couples get somewhat bigger (i.e. more negative) compared with the 'raw' differences. For example, the difference in cognitive test scores at age 3 rises from around 0.10 to 0.16 of a standard deviation after the addition of these controls. This largely reflects the fact that cognitive test scores are relatively low at ages 3 and 5 amongst the ethnic minority groups that are the most likely to be married rather than to cohabit, such as Pakistanis and Bangladeshis. Once such differences are taken into account, the average difference associated with cohabiting compared with marriage therefore gets more negative. On the other hand, the estimated gaps between children from cohabiting and married couples in social and emotional development remain largely unaffected by the addition of these controls. ${ }^{28}$

In our tables of regression results, column $\mathrm{C}$ comes from a model that also contains additional information about the mother's family background and relationship history - namely, whether the mother was ever in care as a child, whether her own parents have separated and whether there are children from her previous relationships within the household. Including these variables in the model reduces the gap between the children of married and cohabiting parents slightly, suggesting that these pre-existing differences between married and cohabiting mothers partly account for the difference in outcomes between children in each household type.

Column D comes from a model that also contains parental education variables as controls. In Chapter 4, we showed that cohabiting parents are, on average, of lower education than married parents. While these additional variables could potentially be affected by the choice of whether to cohabit or marry, we argue that they probably largely reflect differential selection into marriage rather than any causal effect of marriage itself. And since parents' education (especially the mother's) is strongly positively associated both with children's cognitive test scores and with their social and emotional development (see Appendix Tables A3 and A4 for outcomes at age 3 and Tables A5 and A6 for outcomes at age 5), once these differences are taken into account the estimated gap in outcomes between children born to cohabiting parents and those born to married parents shrinks considerably. The resulting gap in cognitive test scores at age 3 is (positive but) not statistically significant, though for the other outcomes the coefficient on the cohabiting indicator remains negative and statistically significant. In all cases, the magnitude of the coefficient is reduced in absolute terms, which suggests that the characteristics of parents included in column D account for a large proportion of the difference in children's outcomes. We believe that all

\footnotetext{
${ }^{28}$ The full regression tables for outcomes at age 3 and age 5 (Appendix Tables A3-A6) show the estimated coefficients on the other variables included in the column B specification. These indicate considerable differences in child outcomes at ages 3 and 5 according to both ethnicity and religion, but little independent effect of parents' immigration status, after controlling for these.
} 
variables included in the specification until this point are almost entirely predetermined before marriage. This suggests that selection unarguably plays a significant role in accounting for the difference in development between children of married and cohabiting couples.

In column E, we additionally control for father's occupation, household income, parental work status and housing tenure when the child was 9 months old. Controlling for these socio-economic status variables in general further reduces the estimated outcome gap between children born to cohabiting couples and those born to married parents quite considerably. This is because cohabitants are typically of lower occupation, income and wealth than married couples, and all of these are very strongly positively associated with child development (see Appendix Tables A3-A6). Indeed, the gap in cognitive outcomes at age 3 becomes positive and significant once these variables are controlled for, suggesting that once these differences are taken into account the children of cohabiting parents in fact do better than those whose parents are married. As we argued in Chapter 4, these indicators of socio-economic status are likely to reflect the type of people who choose to marry (selection), but could also be affected by marriage itself. We cannot guarantee, therefore, that we have not partly controlled away some potentially positive effects of marriage by adding these variables to our model.

Taking our results in columns D and E together would suggest that the main underlying factors that account for the observed developmental differences between children born to cohabiting parents and those born to married couples are the differences in their parents' socio-economic status that are already shown at 9 months old.

In column $\mathrm{F}$, further controls are added for some measures of family structure, including the age of the mother at her first birth, how long the couple have lived together before the birth of the child in the MCS, whether the pregnancy was planned and the birth order of the child in the MCS. While the addition of these variables makes little difference to the estimated gap in cognitive test scores between children born to cohabiting compared with married parents (which remains small and not significantly different from zero), it does further reduce the estimated gap in social and emotional development. This reduction appears to be accounted for by the higher incidence of unplanned pregnancy among cohabiting mothers, which is negatively associated with a child's social and emotional development at ages 3 and $5 .{ }^{29}$ Even after controlling for differences in family structure, it remains the case that children born to cohabiting couples on average show lower social and emotional development than children born to married couples, and these differences, though small in magnitude, are statistically significant.

In column G, we additionally control for the quality of the relationship between the parents, which is selfreported by the mother when the baby is 9 months old. Our analysis reveals a strong positive association between parents' relationship quality and children's social and emotional development (see Appendix Tables A4 and A6). Since self-reported relationship quality is, on average, lower among cohabiting parents than among married parents, including this as a control reduces the estimated gap in social and emotional outcomes between children born to cohabiting and married parents even further, and the estimated gap that remains is no longer statistically significant.

As we discussed in Chapter4, this difference in relationship quality could arise both because it is likely that happier couples make the decision to get married in the first place and because it is possible that marriage itself fosters a better relationship among parents. Since we cannot distinguish between these

\footnotetext{
${ }^{29}$ Appendix Table A4 shows that at age 3, this negative association between unplanned pregnancy and a child's social and emotional development is no longer significant after variables related to mother and child health and well-being are controlled for. This suggests that some of the channels through which unplanned pregnancy might lead to lower social and emotional outcomes for children could be aspects of health, such as smoking in pregnancy, breastfeeding, indicators of depression at 9 months and the child's birthweight.
} 
two explanations in our data, we cannot be certain that by controlling for these differences we are only removing the effects of selection from our estimates. ${ }^{30}$

Taken together, our findings set out in columns A-G of Table 5 suggest the following:

- $\quad$ Children born to cohabiting parents show a small deficit in cognitive development at ages 3 and 5 compared with children born to married parents, but this deficit is largely accounted for by the fact that cohabiting parents are of lower education, occupation, income and housing tenure than married parents. These socio-economic factors in turn could partly be caused by the decision to marry - for example, if the social and legal protections inherent in marriage allow parents to work more effectively and hence enjoy a better standard of living. However, our judgement is that our findings probably largely reflect differential selection. This judgement is strengthened by the large reduction in the difference between children of married and cohabiting couples once we control for factors that we believe are almost entirely determined before the decision to get married (column D). Such a judgement suggests that the gap in cognitive development between children born to cohabiting as opposed to married parents is largely accounted for by their parents' lower level of education and income, and not by their parents not being married.

- Children born to cohabiting parents show a somewhat larger deficit in social and emotional development at ages 3 and 5 compared with children born to married parents. This gap in social and emotional development is reduced by more than half, but remains statistically significant, once differences in parental education and socio-economic status are controlled for. Our judgement is that this suggests that the majority of the gap in social and emotional development between children born to cohabiting as opposed to married parents is largely accounted for by their parents' lower level of education and income, and not by their parents not being married.

- Once differences in family structure (including the likelihood of a pregnancy being unplanned) and the relationship quality when the child is 9 months old are also controlled for, the gap in social and emotional development between the children of married and cohabiting parents becomes even smaller, and is now statistically insignificant. This suggests that the remainder of the difference in social and emotional development for children born to cohabiting as opposed to married couples is accounted for by differences in family structure (including lower rates of planned pregnancy), and parents' lower relationship quality (early on in the child's life). However, our research cannot distinguish the extent to which these differences reflect the sort of people who choose to marry in the first place (since people are likely to choose to marry in part on the basis of the underlying quality of their relationship) and how much they are the positive product of marriage itself (possibly due to the additional social and legal protections that marriage provides).

- It is also interesting to compare our estimates of the outcome gap between married and cohabiting couples with the estimated coefficients on other characteristics in the model; for social and emotional development at age 3 for example, the coefficient on the indicator of cohabitation is -0.060 in the model in column F (in which we control for family structure, but not relationship quality). This is compared to a coefficient of -0.375 for the difference between children who have a mother with no formal educational qualifications compared to those with a degree or higher (see Appendix Table A4). In this context, the difference between children born to married and cohabiting couples is very small.

\footnotetext{
${ }^{30}$ It is also possible that better child development (which we observe at age 3 but could be correlated with development at 9 months) has an effect on the parents' relationship quality. We should therefore also entertain the possibility of reverse causality between children's development and their parents' relationship quality.
} 


\section{Controlling for observable characteristics: those that might be causal pathways}

The regression results displayed in columns $\mathrm{H}-\mathrm{K}$ of Table 5 include controls for observable characteristics that might be causal pathways, through which the decision to cohabit rather than marry might affect children's outcomes. As we are adding these possible pathways into a model that already controls for the variables contained in columns B-G, the introduction of the additional controls should largely allow us to test for causal pathways. As we acknowledged in Chapter 4, however, there remains the possibility that some of these 'pathways' variables could also reflect underlying differences in the selection into marriage that we have been unable to control for using the set of variables contained in columns B-G.

The possible causal pathways that we investigate are:

- changes in parents' self-reported relationship quality, and relationship breakdown and re-partnering, between when the child is 9 months old and the ages of 3 and 5 (column $\mathrm{H}$ );

- changes in parents' work status and income between when the child is 9 months old and the ages of 3 and 5 (column I);

- mother and child health, and health-related behaviours, during pregnancy, birth and up to 9 months (column J);

- $\quad$ parenting practices at ages 3 and 5, including the home learning environment and parenting styles and rules (column $\mathrm{K}$ ).

We showed in Chapter 4 that cohabiting and married parents do differ significantly in quite a number of these dimensions. In particular, cohabiting parents show considerably more relationship instability during the child's early years, a higher incidence of maternal smoking during pregnancy and of post-natal depression (as captured by measures of the mother's malaise at 9 months), and less regularity in household routine. Appendix Tables A3-A6 show that many of these factors are also very strongly related to child outcomes (for example, maternal malaise at 9 months is very strongly negatively related to later child social and emotional outcomes; also, the quality of the home learning environment is strongly positively related to a child's cognitive development).

The most striking thing about the results presented in columns $\mathrm{H}-\mathrm{K}$ of Table 5 is that the inclusion of these variables makes virtually no difference at all to the estimated gaps in child outcomes between those born to cohabiting parents and those born to married couples. The coefficients on the dummy indicator for whether the child's parents are cohabiting at the time of the birth, which are small and not statistically different from zero once all the factors in columns B-G are controlled for, remain small and generally statistically insignificant after the possible causal pathways variables are added. The explanation for this is quite clear: if our results in column G are interpreted as suggesting that there is probably little or no causal effect of marriage compared with cohabiting on child outcomes, the fact that we find no evidence for the presence of any causal pathways is consistent with this.

Taken as a whole, the clearest potential - but debatable - causal pathway suggested by our work is early relationship quality (which was entered in column $\mathrm{G}$ ). The inclusion of this variable reduced the estimated gap in social and emotional outcomes between the children of cohabiting and married couples significantly. While we believe the inclusion of this variable is necessary to reflect some measure of the parents' pre-existing relationship quality, it could be argued that instead this measure is in fact driven by marital status. To show that relationship quality is indeed a causal pathway for the positive impact of marriage, it would need to be established that marriage leads to large improvements in relationship quality by the time the child is 9 months old, which in turn lead to a higher level of social and emotional 
development for children. This cannot be tested for within our current study, but is an area for future research.

\subsection{Results: comparing outcomes of children according to their parents' relationship status up to the age of 3}

In this section, we take into account both that cohabiting parents are likely to be a heterogeneous group and that it may be the relationship status of the parents in the earliest years of a child's life, rather than just at birth, that is important for child outcomes. We do this by dividing the children whose parents were cohabiting at the time of their birth into three subgroups, taking into account whether the cohabiting couples stayed cohabiting, got married or split up, by the time the child reached the age of 3 . Couples that are married when their child is born remain the base group (as in Section 6.1), regardless of whether they split up by the time the child is aged 3 . The main coefficients of interest in these regressions are on indicators of whether a child's parents were:

i) cohabiting at birth and subsequently got married by the age of 3 ;

ii) cohabiting at birth and remained so by the age of 3 ;

iii) cohabiting at birth and split up by the age of 3 .

Since the base group in these regressions remains the same as in our main results shown in Section 6.1 (i.e. all children born to married couples ${ }^{31}$ ), splitting cohabiting couples into these three groups allows us to decompose the coefficient on the cohabiting indicator variable given in Table 5 into the average effect for each of these subgroups.

Our findings, shown in Table 6, suggest that among children born to cohabiting couples, and before controlling for any observable characteristics (column A):

- The outcomes of children born to cohabiting parents who subsequently get married are generally somewhat lower than the outcomes of children of parents who were married at the time of the birth (although this is not the case for cognitive development at the age of 3).

- The outcomes among children born to cohabiting parents who remain cohabiting by the time their child is aged 3 are slightly lower than those of children born to cohabiting parents who get married. ${ }^{32}$

- The most negative outcomes among the children of cohabiting couples are observed among those whose cohabiting parents subsequently split up.

However, controlling for observable characteristics (columns B-G) reveals a story very similar to that discussed in Section 6.1:

- All differences in cognitive development between children born to married couples and those born to cohabiting couples within each of the three subgroups identified become small and insignificant (or, occasionally, positive and significant) once measures of parental education and socio-economic status (i.e. columns D and E) are added into the model.

\footnotetext{
${ }^{31}$ We have also examined an alternative specification in which we restrict the base group to 'stable married parents', i.e. those children whose parents were married at birth and remained so by the age of 3 . In this specification, we added a dummy for having married parents who had split up by the age of 3. While this approach highlighted the negative association between marital breakdown, as well as cohabitation breakdown, and children's outcomes, it did not substantively alter any of our findings as outlined in this section.

${ }^{32}$ This conclusion is drawn from comparing the size of the coefficients for parents who are cohabiting at birth and get married and the size of the coefficients for those who remain cohabiting. For the cognitive development outcomes, the difference is significant at the $10 \%$ level. For the social and emotional development outcomes, the difference is significant at the $1 \%$ level.
} 
- Differences in social and emotional outcomes are reduced, but remain significant after controlling for parental education and socio-economic status (columns D and E). They are then further reduced, and become no longer statistically significant, by the addition of controls for family structure and relationship quality (columns F and G). This is the case even among the subgroup of children born to cohabiting parents who subsequently split up, where the 'raw' outcome gaps were particularly large.

- The inclusion of a limited set of possible causal pathways into the model (columns H-K, but here excluding those relating to relationship breakdown, which are now captured in our relationship status indicators) again does not change the estimated coefficients of interest much, suggesting that there is little evidence that these are causal pathways between cohabitation and child outcomes. 
Table 5. Difference in cognitive and non-cognitive skills (total BAS and SDQ) at age 3 and age 5 between children born to cohabiting biological parents and those born to parents married at birth

\begin{tabular}{|c|c|c|c|c|c|c|c|c|c|c|c|}
\hline & \multicolumn{3}{|c|}{ Fixed characteristics } & \multicolumn{4}{|c|}{$\begin{array}{l}\text { Characteristics mainly reflecting selection, but potentially } \\
\text { capturing causal pathways }\end{array}$} & \multicolumn{4}{|c|}{ Possible causal pathways } \\
\hline & A & B & C & $\mathrm{D}$ & $\mathrm{E}$ & $\mathrm{F}$ & G & $\mathrm{H}$ & I & $\mathrm{J}$ & $\mathrm{K}$ \\
\hline Outcome variable & & & & & & & & & & & \\
\hline BAS at age 3 & $-0.101 * * *$ & $-0.155 * * *$ & $-0.114 * * *$ & 0.011 & $0.081 * *$ & 0.046 & 0.051 & 0.055 & 0.052 & 0.052 & $0.056 *$ \\
\hline BAS at age 5 & $-0.192 * * *$ & $-0.229 * * *$ & $-0.189 * * *$ & $-0.056 *$ & -0.004 & -0.045 & -0.040 & -0.040 & -0.041 & -0.042 & -0.039 \\
\hline SDQ at age 3 & $-0.325 * * *$ & $-0.316 * * *$ & $-0.288 * * *$ & $-0.191 * * *$ & $-0.124 * * *$ & $-0.060 *$ & -0.031 & -0.025 & -0.027 & -0.029 & -0.033 \\
\hline SDQ at age 5 & $-0.301 * * *$ & $-0.291 * * *$ & $-0.263 * * *$ & $-0.177 * * *$ & $-0.119 * * *$ & $-0.076 *$ & -0.045 & -0.038 & -0.039 & -0.037 & -0.036 \\
\hline Child's gender & Yes & Yes & Yes & Yes & Yes & Yes & Yes & Yes & Yes & Yes & Yes \\
\hline Child's year and month of birth & Yes & Yes & Yes & Yes & Yes & Yes & Yes & Yes & Yes & Yes & Yes \\
\hline $\begin{array}{l}\text { Mother's ethnicity, immigration } \\
\text { status and religion }\end{array}$ & No & Yes & Yes & Yes & Yes & Yes & Yes & Yes & Yes & Yes & Yes \\
\hline $\begin{array}{l}\text { Mother's background (ever in } \\
\text { care, parents separated, } \\
\text { children from previous } \\
\text { relationship) }\end{array}$ & No & No & Yes & Yes & Yes & Yes & Yes & Yes & Yes & Yes & Yes \\
\hline Education & No & No & No & Yes & Yes & Yes & Yes & Yes & Yes & Yes & Yes \\
\hline $\begin{array}{l}\text { Father's occupation, household } \\
\text { income, tenure and parents' } \\
\text { work at } 9 \text { months }\end{array}$ & No & No & No & No & Yes & Yes & Yes & Yes & Yes & Yes & Yes \\
\hline Family structure & No & No & No & No & No & Yes & Yes & Yes & Yes & Yes & Yes \\
\hline Relationship quality at 9 months & No & No & No & No & No & No & Yes & Yes & Yes & Yes & Yes \\
\hline $\begin{array}{l}\text { Post } 9 \text { months relationship } \\
\text { quality and stability }\end{array}$ & No & No & No & No & No & No & No & Yes & Yes & Yes & Yes \\
\hline Post 9 months income and work & No & No & No & No & No & No & No & No & Yes & Yes & Yes \\
\hline Child and mother's health & No & No & No & No & No & No & No & No & No & Yes & Yes \\
\hline Parenting & No & No & No & No & No & No & No & No & No & No & Yes \\
\hline No. of observations & 9,951 & 9,951 & 9,951 & 9,951 & 9,951 & 9,951 & 9,951 & 9,951 & 9,951 & 9,951 & 9,951 \\
\hline
\end{tabular}

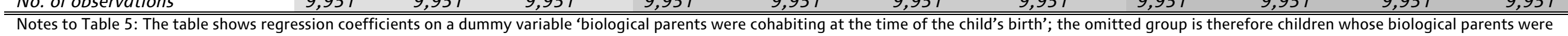

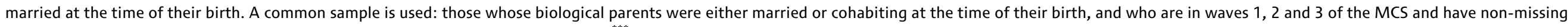
SDQ and BAS scores. Standard errors are clustered by family. * $p<0.05, * * p<0.01,{ }^{* * * *} p<0.001$. 
Table 6. Difference in cognitive and non-cognitive skills (total BAS and total SDQ) at ages 3 and 5 between children born to married and cohabiting biological parents of different marital states when the child is 3 years old

\begin{tabular}{|c|c|c|c|c|c|c|c|c|c|c|c|}
\hline & \multicolumn{3}{|c|}{ Fixed characteristics } & \multicolumn{4}{|c|}{$\begin{array}{l}\text { Characteristics mainly reflecting selection, but potentially } \\
\text { capturing causal pathways }\end{array}$} & \multicolumn{4}{|c|}{ Possible causal pathways } \\
\hline & A & B & $\mathrm{C}$ & $\mathrm{D}$ & $\mathrm{E}$ & $\mathrm{F}$ & G & $\mathrm{H}$ & I & $\mathrm{J}$ & $\mathrm{K}$ \\
\hline \multicolumn{12}{|l|}{ BAS at age 3} \\
\hline $\begin{array}{l}\text { Cohabiting at birth and got } \\
\text { married }\end{array}$ & 0.006 & -0.051 & -0.008 & 0.069 & $0.090 *$ & 0.069 & 0.060 & 0.050 & 0.043 & 0.041 & 0.048 \\
\hline Cohabiting at birth and stayed so & $-0.072 *$ & $-0.131 * * *$ & $-0.094 * *$ & 0.021 & $0.086 * *$ & 0.045 & 0.044 & 0.037 & 0.034 & 0.040 & 0.044 \\
\hline Cohabiting at birth and split up & $-0.324 * * *$ & $-0.369 * * *$ & $-0.323 * * *$ & $-0.112 *$ & 0.044 & -0.007 & 0.065 & $0.166^{*}$ & $0.177^{*}$ & $0.156^{*}$ & $0.150 *$ \\
\hline \multicolumn{12}{|l|}{ BAS at age 5} \\
\hline $\begin{array}{l}\text { Cohabiting at birth and got } \\
\text { married }\end{array}$ & $-0.125 * *$ & $-0.165 * * *$ & $-0.123 * *$ & -0.032 & -0.015 & -0.040 & -0.048 & -0.055 & -0.055 & -0.057 & -0.053 \\
\hline Cohabiting at birth and stayed so & $-0.162 * * *$ & $-0.204 * * *$ & $-0.167 * * *$ & -0.043 & 0.007 & -0.039 & -0.041 & -0.048 & -0.051 & -0.049 & -0.044 \\
\hline Cohabiting at birth and split up & $-0.366 * * *$ & $-0.391 * * *$ & $-0.344 * * *$ & $-0.134 * *$ & -0.019 & -0.085 & -0.018 & 0.057 & 0.061 & 0.047 & 0.034 \\
\hline \multicolumn{12}{|l|}{ SDQ at age 3} \\
\hline $\begin{array}{l}\text { Cohabiting at birth and got } \\
\text { married }\end{array}$ & $-0.237 * * *$ & $-0.239 * * *$ & $-0.211 * * *$ & $-0.145 * * *$ & $-0.124 * *$ & -0.065 & -0.077 & -0.078 & -0.082 & -0.077 & -0.075 \\
\hline Cohabiting at birth and stayed so & $-0.287 * * *$ & $-0.278 * * *$ & $-0.253 * * *$ & $-0.166 * * *$ & $-0.103 * *$ & -0.050 & -0.011 & -0.003 & -0.006 & -0.013 & -0.018 \\
\hline Cohabiting at birth and split up & $-0.550 * * *$ & $-0.534 * * *$ & $-0.494 * * *$ & $-0.344 * * *$ & $-0.201 * * *$ & -0.093 & -0.006 & 0.012 & 0.022 & 0.024 & 0.015 \\
\hline \multicolumn{12}{|l|}{ SDQ at age 5} \\
\hline $\begin{array}{l}\text { Cohabiting at birth and got } \\
\text { married }\end{array}$ & $-0.211 * * *$ & $-0.211 * * *$ & $-0.182 * * *$ & $-0.123 * *$ & $-0.099 *$ & -0.062 & -0.076 & -0.071 & -0.073 & -0.063 & -0.060 \\
\hline Cohabiting at birth and stayed so & $-0.265 * * *$ & $-0.259 * * *$ & $-0.234 * * *$ & $-0.156 * * *$ & $-0.103 * *$ & $-0.072 *$ & -0.031 & -0.022 & -0.024 & -0.028 & -0.028 \\
\hline Cohabiting at birth and split up & $-0.519 * * *$ & $-0.495 * * *$ & $-0.457 * * *$ & $-0.334 * * *$ & $-0.218 * * *$ & $-0.133 *$ & -0.028 & -0.029 & -0.021 & -0.009 & -0.007 \\
\hline Child's gender & Yes & Yes & Yes & Yes & Yes & Yes & Yes & Yes & Yes & Yes & Yes \\
\hline Child's year and month of birth & Yes & Yes & Yes & Yes & Yes & Yes & Yes & Yes & Yes & Yes & Yes \\
\hline $\begin{array}{l}\text { Mother's ethnicity, immigration } \\
\text { status and religion }\end{array}$ & No & Yes & Yes & Yes & Yes & Yes & Yes & Yes & Yes & Yes & Yes \\
\hline $\begin{array}{l}\text { Mother's background (ever in } \\
\text { care, parents separated, } \\
\text { children from previous } \\
\text { relationship) }\end{array}$ & No & No & Yes & Yes & Yes & Yes & Yes & Yes & Yes & Yes & Yes \\
\hline Education & No & No & No & Yes & Yes & Yes & Yes & Yes & Yes & Yes & Yes \\
\hline $\begin{array}{l}\text { Father's occupation, household } \\
\text { income, tenure and parents' } \\
\text { work at } 9 \text { months }\end{array}$ & No & No & No & No & Yes & Yes & Yes & Yes & Yes & Yes & Yes \\
\hline Family structure & No & No & No & No & No & Yes & Yes & Yes & Yes & Yes & Yes \\
\hline $\begin{array}{l}\text { Relationship quality at } 9 \\
\text { months }\end{array}$ & No & No & No & No & No & No & Yes & Yes & Yes & Yes & Yes \\
\hline $\begin{array}{l}\text { Post } 9 \text { months relationship } \\
\text { quality and stability }\end{array}$ & No & No & No & No & No & No & No & Yes & Yes & Yes & Yes \\
\hline Post 9 months income and work & No & No & No & No & No & No & No & No & Yes & Yes & Yes \\
\hline Child and mother's health & No & No & No & No & No & No & No & No & No & Yes & Yes \\
\hline Parenting & No & No & No & No & No & No & No & No & No & No & Yes \\
\hline No. of observations & 9,951 & 9,951 & 9,951 & 9,951 & 9,951 & 9,951 & 9,951 & 9,951 & 9,951 & 9,951 & 9,951 \\
\hline
\end{tabular}




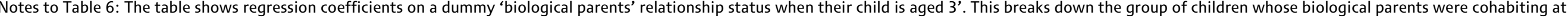

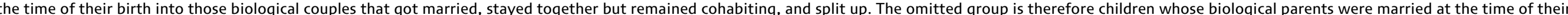

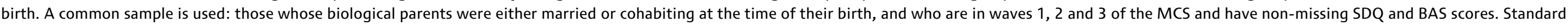
errors are clustered by family. $* p<0.05, * * p<0.01, * * * p<0.001$. 


\section{Conclusions}

There is a vigorous debate about the benefits of marriage that has focused on whether formal marriage is a better environment for children than parental cohabitation. We have shown that the children of married parents do better than the children of cohabiting couples in a number of dimensions, particularly on measures of social and emotional development at the ages of 3 and 5.

But we have also shown that parents who are married differ from those who are cohabiting in very substantial ways, particularly relating to their ethnicity, education and socio-economic status, and their history of relationship stability and the quality of their relationship even when the child is at a very young age. Once we take these factors into account, there are no longer any statistically significant differences in these child outcomes between children of married and cohabiting parents.

What is the policy significance of these findings? Our own work cannot decisively conclude whether a causal marriage effect exists. We do observe, however, that much of the gap in educational and social and emotional outcomes between the children of cohabiting and married parents appears to be due to differential selection into marriage compared with cohabitation, largely on the basis of parental education and socio-economic status. These characteristics of the parents explain differences in cognitive development almost entirely, while some differences in social and emotional development remain. Much of the remaining difference in social and emotional outcomes is accounted for by differences in relationship quality between parents who are married and cohabiting when their child is born. It is debatable whether this also largely reflects selection into marriage, or reflects a possible causal pathway for a positive benefit of marriage itself.

For our research to indicate a significant positive causal effect of marriage, it would need to be shown that marriage leads to large improvements in parents' characteristics by the time the child is 9 months old, which in turn lead to better social and emotional outcomes for children. This seems unlikely in the case of parental education and socio-economic status. It is debatable whether relationship quality is what causes marriage or whether, even early on, being married itself improves relationship quality.

The next stage of our work will be based on an analysis of the children of the British Cohort Study, for whom we have measures of many more pre-existing parental characteristics that are unobserved in the Millennium Cohort Study (including parental cognitive and social skills, and parental relationship histories over the whole of their adult lives). We hope to get closer to a definitive answer in this future work. 


\section{Appendix tables}

Table A1. Description of additional variables included in our analysis

\begin{tabular}{|c|c|}
\hline Variable & Description \\
\hline \multicolumn{2}{|c|}{ Demographic variables for the child } \\
\hline Year of birth & The year the child was born, which varies from 2000 to 2002 . \\
\hline Month of birth & The month the child was born. \\
\hline Gender & The gender of the child. \\
\hline \multicolumn{2}{|c|}{ Mother's background and religion } \\
\hline Ethnicity & $\begin{array}{l}\text { Grouped into nine categories: White, Black Caribbean, Black } \\
\text { African, Indian, Pakistani, Bangladeshi, other Asian background, } \\
\text { mixed from any background, other. }\end{array}$ \\
\hline Immigrant status & $\begin{array}{l}\text { Whether the mother of the child was born in the UK. Also } \\
\text { whether the grandmother and grandfather on the mother's side } \\
\text { of the family were born in the UK. }\end{array}$ \\
\hline Religion & $\begin{array}{l}\text { Self-reported religion at wave } 1 \text { of the survey. Grouped into } \\
\text { nine categories: none, Roman Catholic, Church of England, other } \\
\text { Christian, Hindu, Muslim, Sikh, other, missing. }\end{array}$ \\
\hline Ever in care as a child & $\begin{array}{l}\text { Whether the mother of the child was ever in care when she was } \\
\text { a child. This is self-reported when the child is aged } 9 \text { months. }\end{array}$ \\
\hline Own parents separated & $\begin{array}{l}\text { Whether the mother of the child's parents ever separated. This } \\
\text { is self-reported when the child is aged } 9 \text { months. }\end{array}$ \\
\hline Children from previous partner & $\begin{array}{l}\text { Whether there are any step- or half-siblings of the child in the } \\
\text { household. This is derived from the household grid when the } \\
\text { child is } 9 \text { months old. }\end{array}$ \\
\hline
\end{tabular}

Parents' educational qualifications

Highest level of education for both parents

Mother has problems reading
Parents' highest level of educational qualification at wave 1 , grouped into six categories: NVQ level 687 (degree or MSc), NVQ level 4\&5 (higher BTEC national diploma and foundation degree), NVQ level 3 (A/AS level), NVQ level 2 (GSCE grades $A *$ C), NVQ level 1 (BTEC entry level), none.

Whether the mother reports having difficulty reading children's books and/or forms. This is reported in wave 1 of the survey.

Early occupation, income and housing tenure

National Statistics Socio-Economic Classification (NSSEC) of the

father's occupation

Household income at wave 1

Housing tenure at wave 1
Classification of father's employment at wave 1, grouped into eight categories: high managerial and professional, low managerial and professional, intermediate, small employer and self-employed, low supervisory and technical, semi-routine, routine, missing.

Household income is taken from a derived variable in the MCS data, in which income is equivalised using modified OECD equivalence scales (which allow household income to be adjusted for the number of people in the household). We standardise this variable and create household quintiles, which split households into five equal-sized groups ranging from lowest $20 \%$ of household income to highest $20 \%$ of household income.

Housing tenure of the family is split into six groups: own or mortgage home, rent privately, rent from the local authority, live with parents, other, missing. 


\begin{tabular}{ll}
\hline \hline Variable & Description \\
\hline Mother's employment at wave 1 & $\begin{array}{l}\text { Asked of mothers and grouped into five categories: currently } \\
\text { doing paid work, never had a paid job, has worked in the past } \\
\text { but does not work currently, has a paid job but is on leave, } \\
\text { missing. }\end{array}$ \\
Father's employment at wave 1 & $\begin{array}{l}\text { Asked of fathers and grouped into four categories: currently } \\
\text { doing paid work, never had a paid job, has worked in the past } \\
\text { but does not work currently, missing. }\end{array}$ \\
\hline
\end{tabular}

Family structure and age of parents

Age of parents when the oldest child Age of the parents when the oldest biological child of both in the family was born parents in the family was born. Derived from the household grid when the child in the survey was 9 months old.

Single or multiple birth Whether the child in the survey was a single birth, a twin or a triplet.

Length of relationship The length of time that the couple had lived together prior to the birth of the child in the survey. This was derived from questions in wave 1 of the survey, and coded into eight categories: lived together for less than 9 months, between 9 months and 2 years, between 2 and 4 years, between 4 and 6 years, between 6 and 8 years, between 8 and 10 years, over 10 years, missing.

Planned pregnancy Asked of mothers at wave 1 of the survey, who responded yes or no. We code this into a binary variable.

Birth order Birth order of the child surveyed for the MCS in the household. This measure also includes any step- or half-siblings in the household. We group the variable as follows: first-born, secondborn, third-born, fourth-born, fifth-born or higher.

Contact with grandmother Asked of mothers at wave 1 of the survey. Their responses are grouped into six categories: every day, 3-6 times per week, once or twice per week, at least once a month but not every week, once every few months, once a year or less.

\section{Early relationship quality}

Relationship quality at wave 1
The MCS questionnaire at wave 1 asked mothers the extent to which they agree or disagree with a series of nine questions about their relationship with their partner - for example, 'My partner is usually sensitive and aware of my needs'. The answers to these questions created a scale of happiness in the relationship, which we standardise on the sample.

\section{Household income and employment at later stages \\ Mother in work at waves 2 and $3 \quad$ Categorical variables for whether the mother reports being in work at wave 2 and wave 3. \\ Household income at wave $2 \quad$ We use an equivalent measure of household income to that in wave 1. Again, we standardise this variable and create household quintiles, which split households into five equal-sized groups ranging from lowest $20 \%$ of household income to highest $20 \%$ of household income.}

Later relationship quality and stability

Relationship quality at wave $2 \quad$ The MCS questionnaire at wave 2 asked mothers the extent to which they agree or disagree with a series of five questions about their relationship with their partner - for example, 'My partner is usually sensitive and aware of my needs'. The answers to these questions created a scale of happiness in the relationship, which we standardise on the sample.

Relationship quality at wave 3 As above, in the wave 3 questionnaire. 


\begin{tabular}{ll}
\hline Variable & Description \\
\hline $\begin{array}{l}\text { Couple split for a month or more up } \\
\text { until wave } 2\end{array}$ & $\begin{array}{l}\text { A binary variable created for whether the couple experienced a } \\
\text { period of separation of at least one month from when the child } \\
\text { was born to when the child was roughly aged 3. This period of } \\
\text { separation could include a permanent or temporary separation. }\end{array}$ \\
Couple not living together at wave 2 & $\begin{array}{l}\text { A binary variable created for whether only one biological parent } \\
\text { is in the household at wave } 2 \text { of the survey. }\end{array}$ \\
Couple not living together at wave 3 & $\begin{array}{l}\text { A binary variable created for whether only one biological parent } \\
\text { is in the household at wave } 3 \text { of the survey. }\end{array}$ \\
No new partner by wave 2 & $\begin{array}{l}\text { A binary variable created for whether the natural parent (usually } \\
\text { the mother) has a new partner in the household at wave } 2 \text { of the } \\
\text { survey. }\end{array}$ \\
No new partner by wave 3 & $\begin{array}{l}\text { A binary variable created for whether the natural parent (usually } \\
\text { the mother) has a new partner in the household at wave } 3 \text { of the } \\
\text { survey. }\end{array}$ \\
\hline Health and health-related behaviour & A categorical variable for whether mothers reported \\
breastfeeding at wave 1 of the survey, and for how long, \\
grouped into eight categories: no breastfeeding, breastfed for \\
less than 1 month, 1 to 2 months, 2 to 3 months, 3 to 4 months, \\
4 to 5 months, 5 to 6 months, more than 6 months. \\
Indicators for whether the mother has ever smoked, and \\
whether the mother smokes at wave 1 of the survey. Also a \\
binary variable for whether anyone in the household smokes in \\
the same room as the child at 9 months. \\
Weight at birth measured in kilograms. \\
Length of gestation measured in days. \\
Whether mother suffered from post-natal depression. This is \\
indicated by the mother's maternal malaise score, which is \\
derived from a series of questions in the MCS survey when the \\
child is 9 months old.
\end{tabular}

Parenting practices and self-reported parenting competency

Reading to the child

A binary variable is created for how often parents read to their child at age 3.

Father's involvement with the child A scale based on three questions answered at wave 1 of the survey and standardised. Fathers are asked how often they look after the child on their own, how often they change nappies and how often they feed the child.

Home learning environment (index) Elements of the home learning environment at ages 3 and 5 (reading, library visits, nursery rhymes, crafts, songs, drawing) are scored and the total is standardised.

Self-reported parenting competency Binary variables for whether parents rate themselves as 'good' or 'very good' parents.

Bedtimes Whether the child has a regular bedtime at age 3 .

Mealtimes Whether the child has regular mealtimes at age 3 .

Rules Binary variable for whether there are lots of rules in the household (reported by the mother). Also a binary variable for whether these rules are strictly enforced.

Television

Binary variable for whether the child watches more than 3 hours of television per day at age 3 .

Note: Wave 1 refers to the first wave of the survey, carried out when the child in the MCS survey was around 9 months old. Wave 2 refers to the second wave of the survey, when the child was around 3 years old. Wave 3 refers to the third wave of the survey, when the child was around 5 years old. 
Table A2. Results from a probit regression model of the probability that a couple living together is married

\begin{tabular}{|c|c|c|}
\hline & $\begin{array}{l}\text { Controlling for variables } \\
\text { that probably largely reflect } \\
\text { selection into marriage } \\
\text { (cols B-G in main analysis) }\end{array}$ & $\begin{array}{c}\text { Controlling for variables } \\
\text { that may also reflect causal } \\
\text { pathways } \\
\text { (cols H-K in main analysis) }\end{array}$ \\
\hline \multicolumn{3}{|l|}{ Mother's ethnicity } \\
\hline Black Caribbean & -0.052 & -0.062 \\
\hline Black African & -0.051 & -0.064 \\
\hline Indian & $0.177^{\pi *}$ & $0.163^{\pi *}$ \\
\hline Pakistani & $0.216^{* * *}$ & $0.209^{* * * *}$ \\
\hline Bangladeshi & $0.220^{\pi * \pi}$ & $0.218^{\pi \pi \pi}$ \\
\hline Other Asian background & 0.145 & 0.124 \\
\hline Mixed, any background & -0.086 & -0.078 \\
\hline Other & 0.090 & 0.083 \\
\hline \multicolumn{3}{|l|}{ Immigrant status } \\
\hline Mother was born outside UK & 0.041 & 0.034 \\
\hline Grandmother was born outside UK & 0.003 & 0.000 \\
\hline Grandfather was born outside UK & 0.010 & 0.023 \\
\hline \multicolumn{3}{|l|}{ Mother's religion at child's birth } \\
\hline Roman Catholic & $0.088^{\pi m \pi}$ & $0.086^{\pi \pi \pi}$ \\
\hline Church of England & $0.107^{* * * *}$ & $0.099^{* \cdots *}$ \\
\hline Other Christian & $0.150^{n \pi x}$ & $0.146^{\pi x \pi}$ \\
\hline Hindu & $0.211^{* * * *}$ & $0.210 * \cdots *$ \\
\hline Muslim & $0.237^{\pi * \pi}$ & $0.233^{* \pi *}$ \\
\hline Sikh & $0.230^{* * *}$ & $0.225^{* \pi *}$ \\
\hline Other & $0.178^{* * * *}$ & $0.182^{* * * *}$ \\
\hline \multicolumn{3}{|l|}{ Mother's background characteristics } \\
\hline Ever in care as a child & 0.059 & 0.056 \\
\hline Own parents separated & $-0.052^{\pi * \pi}$ & $-0.046^{\pi * \pi}$ \\
\hline Children from previous partner & $-0.140^{* * * *}$ & $-0.118^{* * *}$ \\
\hline \multicolumn{3}{|l|}{ Father's level of education } \\
\hline NVQ4\&5 - foundation degree & -0.042 & -0.029 \\
\hline NVQ3 - AS/A & $-0.042^{\approx}$ & -0.033 \\
\hline NVQ2 - GCSE A*-C & $-0.063^{m \pi}$ & $-0.052^{*}$ \\
\hline NVQ1 - BTEC entry level & $-0.070^{\pi}$ & -0.062 \\
\hline None & -0.061 & -0.043 \\
\hline \multicolumn{3}{|l|}{ Mother's level of education } \\
\hline NVQ4\&5 - foundation degree & $-0.055^{*}$ & $-0.047^{*}$ \\
\hline$N V Q 3-A S / A$ & $-0.049^{*}$ & -0.042 \\
\hline NVQ2 - GCSE A*-C & $-0.064^{\pi n \pi}$ & $-0.055^{* \pi}$ \\
\hline NVQ1 - BTEC entry level & $-0.082^{*}$ & $-0.073^{*}$ \\
\hline None & $-0.103^{\pi \pi}$ & $-0.082^{\pi}$ \\
\hline Mother has problems reading & 0.002 & 0.000 \\
\hline \multicolumn{3}{|l|}{ Father's NSSEC } \\
\hline Low manager/professional & 0.003 & 0.010 \\
\hline Intermediate & 0.011 & 0.015 \\
\hline Small employer \& self-employed & $-0.065^{*}$ & -0.047 \\
\hline
\end{tabular}




\begin{tabular}{|c|c|c|}
\hline & $\begin{array}{l}\text { Controlling for variables } \\
\text { that probably largely reflect } \\
\text { selection into marriage } \\
\text { (cols B-G in main analysis) }\end{array}$ & $\begin{array}{c}\text { Controlling for variables } \\
\text { that may also reflect causal } \\
\text { pathways } \\
\text { (cols H-K in main analysis) }\end{array}$ \\
\hline Low supervisory \& technical & -0.024 & -0.017 \\
\hline Semi-routine & 0.001 & 0.003 \\
\hline Routine & -0.039 & -0.026 \\
\hline \multicolumn{3}{|l|}{ Housing tenure } \\
\hline Rent privately & $-0.073^{\pi \pi}$ & $-0.065^{\pi}$ \\
\hline Rent from local authority & $-0.074 * * *$ & $-0.061^{* *}$ \\
\hline Live with parents & -0.101 & $-0.113^{\pi}$ \\
\hline Other & 0.083 & 0.074 \\
\hline \multicolumn{3}{|l|}{ Household income at wave 1} \\
\hline $4^{\text {th }}$ quintile & -0.007 & 0.001 \\
\hline $3^{\text {rd }}$ quintile & 0.010 & 0.013 \\
\hline $2^{\text {nd }}$ quintile & -0.024 & -0.020 \\
\hline Lowest quintile & -0.040 & -0.035 \\
\hline \multicolumn{3}{|l|}{ Mother's employment at wave 1} \\
\hline Never had a paid job & -0.036 & -0.051 \\
\hline $\begin{array}{l}\text { Has worked in the past but no current } \\
\text { paid job }\end{array}$ & -0.001 & -0.004 \\
\hline Has paid job but on leave & 0.037 & 0.041 \\
\hline \multicolumn{3}{|l|}{ Father's employment at wave 1} \\
\hline Never had a paid job & -0.254 & -0.311 \\
\hline $\begin{array}{l}\text { Has worked in the past but no current } \\
\text { paid job }\end{array}$ & -0.007 & -0.020 \\
\hline \multicolumn{3}{|l|}{ Mother's age at her first child } \\
\hline $12-19$ & $-0.136^{* *}$ & $-0.121^{* *}$ \\
\hline $20-24$ & -0.062 & -0.051 \\
\hline $25-29$ & -0.001 & 0.007 \\
\hline $30-35$ & -0.020 & -0.016 \\
\hline \multicolumn{3}{|l|}{ Father's age at his first child } \\
\hline $12-19$ & 0.000 & 0.028 \\
\hline $20-24$ & 0.049 & 0.060 \\
\hline $25-29$ & 0.042 & 0.051 \\
\hline $30-35$ & 0.026 & 0.033 \\
\hline \multicolumn{3}{|l|}{ Father's age at wave 1} \\
\hline $12-19$ & -0.150 & -0.248 \\
\hline $20-24$ & -0.067 & -0.078 \\
\hline $25-29$ & -0.030 & -0.040 \\
\hline $30-35$ & 0.001 & -0.006 \\
\hline \multicolumn{3}{|l|}{ Multiple birth } \\
\hline Twin & 0.008 & -0.039 \\
\hline Triplet & 0.158 & 0.137 \\
\hline \multicolumn{3}{|l|}{ Length of cohabitation prior to birth } \\
\hline 8 to 10 years & -0.027 & -0.030 \\
\hline 6 to 8 years & $-0.067^{\pi}$ & $-0.070^{\pi}$ \\
\hline 4 to 6 years & $-0.147^{* * * *}$ & $-0.150^{* * * *}$ \\
\hline 2 to 4 years & $-0.284^{\pi \times \pi}$ & $-0.289^{* \pi \pi}$ \\
\hline
\end{tabular}




\begin{tabular}{|c|c|c|}
\hline & $\begin{array}{l}\text { Controlling for variables } \\
\text { that probably largely reflect } \\
\text { selection into marriage } \\
\text { (cols B-G in main analysis) }\end{array}$ & $\begin{array}{c}\text { Controlling for variables } \\
\text { that may also reflect causal } \\
\text { pathways } \\
\text { (cols H-K in main analysis) }\end{array}$ \\
\hline 9 months to 2 years & $-0.430^{n \pi \pi}$ & $-0.435^{n \pi m}$ \\
\hline Less than 9 months & $-0.665^{\ldots * *}$ & $-0.673^{\ldots * *}$ \\
\hline Pregnancy was unplanned & $-0.137^{1 * \pi *}$ & $-0.130^{w * \pi}$ \\
\hline \multicolumn{3}{|l|}{ Birth order (all siblings) } \\
\hline $2^{\text {nd }}$ & $0.051^{* \cdots *}$ & $0.044^{\pi \pi}$ \\
\hline $3^{\text {rd }}$ & $0.090^{* * *}$ & $0.074^{* * *}$ \\
\hline $4^{\text {th }}$ & $0.108^{\pi \cdots \pi}$ & $0.089^{* *}$ \\
\hline $5^{\text {th }}$ or higher & $0.134^{* \cdots * *}$ & $0.116^{* *}$ \\
\hline \multicolumn{3}{|l|}{ Contact with grandmother } \\
\hline 3-6 times per week & -0.011 & -0.015 \\
\hline Once/twice per week & 0.004 & -0.001 \\
\hline $\begin{array}{l}\text { At least once a month but not every } \\
\text { week }\end{array}$ & 0.008 & 0.003 \\
\hline Once every few months & 0.013 & 0.011 \\
\hline Once a year or less & 0.015 & 0.007 \\
\hline $\begin{array}{l}\text { Relationship quality at wave } 1 \\
\text { (in standard deviations) }\end{array}$ & $0.040^{* * *}$ & $0.031^{* * *}$ \\
\hline $\begin{array}{l}\text { Relationship quality at wave } 2 \\
\text { (in standard deviations) }\end{array}$ & & 0.011 \\
\hline $\begin{array}{l}\text { Relationship quality at wave } 3 \\
\text { (in standard deviations) }\end{array}$ & & 0.002 \\
\hline \multicolumn{3}{|l|}{ Relationship stability } \\
\hline $\begin{array}{l}\text { Couple split for a month or more up } \\
\text { until wave } 2\end{array}$ & & -0.054 \\
\hline Couple not living together at wave 2 & & -0.022 \\
\hline Couple not living together at wave 3 & & -0.012 \\
\hline No new partner by wave 2 & & -0.038 \\
\hline No new partner by wave 3 & & 0.023 \\
\hline \multicolumn{3}{|l|}{ Employment at waves 2 and 3} \\
\hline Mother not in work at wave 2 & & 0.017 \\
\hline Mother not in work at wave 3 & & 0.005 \\
\hline \multicolumn{3}{|l|}{ Household income at wave 2} \\
\hline $4^{\text {th }}$ quintile & & -0.033 \\
\hline $3^{\text {rd }}$ quintile & & -0.015 \\
\hline $2^{\text {nd }}$ quintile & & 0.023 \\
\hline Lowest quintile & & -0.000 \\
\hline \multicolumn{3}{|l|}{ Mother and child health } \\
\hline Birthweight (kg) & & $0.028^{\prime \prime}$ \\
\hline Gestation (days) & & $-0.001^{*}$ \\
\hline Mother has ever smoked & & $-0.038^{\pi}$ \\
\hline Mother smokes at wave 1 & & $-0.067^{* * *}$ \\
\hline $\begin{array}{l}\text { Someone in the house smokes around } \\
\text { the child at } 9 \text { months }\end{array}$ & & 0.019 \\
\hline Breastfed for $5-6$ months & & -0.040 \\
\hline Breastfed for $4-5$ months & & 0.008 \\
\hline Breastfed for 3-4 months & & -0.055 \\
\hline
\end{tabular}




\begin{tabular}{|c|c|c|}
\hline & $\begin{array}{l}\text { Controlling for variables } \\
\text { that probably largely reflect } \\
\text { selection into marriage } \\
\text { (cols B-G in main analysis) }\end{array}$ & $\begin{array}{c}\text { Controlling for variables } \\
\text { that may also reflect causal } \\
\text { pathways } \\
\text { (cols H-K in main analysis) }\end{array}$ \\
\hline Breastfed for 2-3 months & & -0.018 \\
\hline Breastfed for $1-2$ months & & 0.014 \\
\hline Breastfed for less than 1 month & & -0.026 \\
\hline No breastfeeding & & -0.048 \\
\hline Index of mother's malaise is 1 & & -0.021 \\
\hline Index of mother's malaise is 2 & & -0.020 \\
\hline Index of mother's malaise is 3 & & 0.035 \\
\hline $\begin{array}{l}\text { Index of mother's malaise is } 4 \text { or } \\
\text { greater }\end{array}$ & & 0.029 \\
\hline \multicolumn{3}{|l|}{ Parenting practices and home life } \\
\hline Child is not read to daily & & -0.017 \\
\hline $\begin{array}{l}\text { Father's involvement with baby at } \\
\text { wave } 1 \text { (in standard deviations) }\end{array}$ & & $0.017^{*}$ \\
\hline $\begin{array}{l}\text { Home learning environment at wave } 2 \\
\text { (in standard deviations) }\end{array}$ & & -0.011 \\
\hline $\begin{array}{l}\text { Home learning environment at wave } 3 \\
\text { (in standard deviations) }\end{array}$ & & 0.003 \\
\hline $\begin{array}{l}\text { Mother not self-rated as very good } \\
\text { parent }\end{array}$ & & 0.004 \\
\hline Mother not self-rated as good parent & & -0.011 \\
\hline $\begin{array}{l}\text { Father not self-rated as very good } \\
\text { parent }\end{array}$ & & 0.024 \\
\hline Father not self-rated as good parent & & 0.012 \\
\hline Child does not have regular bedtime & & $-0.030^{\pi}$ \\
\hline Child does not have regular mealtimes & & -0.014 \\
\hline Child does not have many rules & & -0.001 \\
\hline Rules are not strictly enforced & & 0.008 \\
\hline More than 3 hours of TV per day & & 0.026 \\
\hline No. of observations & 9,951 & 9,951 \\
\hline
\end{tabular}

Notes: A common sample is used: couples that were married or cohabiting when the child in the MCS survey was born, that are in waves 1, 2 and 3, and that have non-missing SDQ and BAS scores. In some cases, parents have missing characteristics; in these cases, missing dummies are included in the regression but not reported in this table. Standard errors are clustered by family. " $p<0.05,{ }^{* * *} p<0.01,{ }^{* * * *} p<0.001$. 
Table A3. Difference in cognitive skills (total BAS) at age 3 between children born to cohabiting biological parents and those born to parents married at birth

\begin{tabular}{|c|c|c|c|c|c|c|c|c|c|c|c|}
\hline & \multicolumn{3}{|c|}{ Fixed characteristics } & \multicolumn{4}{|c|}{$\begin{array}{l}\text { Characteristics mainly reflecting selection, but } \\
\text { potentially capturing causal pathways }\end{array}$} & \multicolumn{4}{|c|}{ Possible causal pathways } \\
\hline & Raw & Ethnicity & $\begin{array}{l}\text { Mother's } \\
\text { background }\end{array}$ & Education & $\begin{array}{l}\text { Occupation, } \\
\text { income, } \\
\text { tenure and } \\
\text { working at } \\
9 \text { months }\end{array}$ & $\begin{array}{l}\text { Family } \\
\text { structure and } \\
\text { relationship } \\
\text { duration prior } \\
\text { to birth }\end{array}$ & $\begin{array}{l}\text { Relationship } \\
\text { quality at } 9 \\
\text { months }\end{array}$ & $\begin{array}{l}\text { Post } 9 \\
\text { months } \\
\text { relationship } \\
\text { quality \& } \\
\text { stability }\end{array}$ & $\begin{array}{l}\text { Post } 9 \\
\text { months } \\
\text { income \& } \\
\text { working }\end{array}$ & $\begin{array}{l}\text { Mother and } \\
\text { child health }\end{array}$ & Parenting \\
\hline & A & B & C & $\mathrm{D}$ & $\mathrm{E}$ & $\mathrm{F}$ & G & $\mathrm{H}$ & 1 & J & K \\
\hline \multicolumn{12}{|l|}{ Coefficient of interest } \\
\hline Cohabiting at birth & $-0.101 * * *$ & $-0.155 * * *$ & $-0.114 * * *$ & 0.011 & $0.081 * *$ & 0.046 & 0.051 & 0.055 & 0.052 & 0.052 & $0.056 *$ \\
\hline \multicolumn{12}{|l|}{ Mother's ethnicity } \\
\hline Black Caribbean & & $-0.563 * * *$ & $-0.524 * * *$ & $-0.443 * * *$ & $-0.367 * *$ & $-0.377 * *$ & $-0.352 * *$ & $-0.352 * *$ & $-0.354 * *$ & $-0.388 * *$ & $-0.351 * *$ \\
\hline Black African & & $-0.524 * * *$ & $-0.536 * * *$ & $-0.514 * * *$ & $-0.390 * *$ & $-0.319 * *$ & $-0.315 * *$ & $-0.313 * *$ & $-0.310 * *$ & $-0.326 * *$ & $-0.257 *$ \\
\hline Indian & & -0.237 & -0.293 & $-0.315 *$ & -0.255 & -0.256 & -0.254 & $-0.262 *$ & -0.255 & -0.237 & -0.259 \\
\hline Pakistani & & $-0.692 * * *$ & $-0.726 * * *$ & $-0.540 * * *$ & $-0.457 * *$ & $-0.455 * *$ & $-0.461 * *$ & $-0.465 * *$ & $-0.451 * *$ & $-0.416 * *$ & $-0.434 * *$ \\
\hline Bangladeshi & & $-0.848 * * *$ & $-0.884 * * *$ & $-0.693 * * *$ & $-0.539 * *$ & $-0.516 * *$ & $-0.514 * *$ & $-0.517 * *$ & $-0.514 * *$ & $-0.496 * *$ & $-0.482 * *$ \\
\hline Other Asian background & & -0.190 & -0.248 & -0.160 & -0.097 & -0.154 & -0.130 & -0.132 & -0.119 & -0.095 & -0.075 \\
\hline Mixed, any background & & -0.135 & -0.125 & -0.162 & -0.142 & -0.130 & -0.127 & -0.131 & -0.131 & -0.162 & -0.138 \\
\hline Other & & -0.284 & -0.290 & $-0.336 *$ & $-0.319 *$ & $-0.321 *$ & $-0.313 *$ & $-0.312 *$ & $-0.306 *$ & $-0.304 *$ & $-0.279 *$ \\
\hline \multicolumn{12}{|l|}{ Immigrant status } \\
\hline $\begin{array}{l}\text { Mother was born outside } \\
\text { UK }\end{array}$ & & $-0.169 * *$ & $-0.177 * * *$ & $-0.186 * * *$ & $-0.164 * *$ & $-0.143 * *$ & $-0.134 * *$ & $-0.137 * *$ & $-0.137 * *$ & $-0.149 * *$ & $-0.135 * *$ \\
\hline $\begin{array}{l}\text { Grandmother was born } \\
\text { outside UK }\end{array}$ & & 0.025 & 0.026 & -0.013 & -0.030 & -0.021 & -0.025 & -0.027 & -0.026 & -0.029 & -0.016 \\
\hline $\begin{array}{l}\text { Grandfather was born } \\
\text { outside UK }\end{array}$ & & -0.012 & -0.004 & -0.023 & -0.024 & -0.012 & -0.012 & -0.012 & -0.015 & -0.014 & -0.015 \\
\hline \multicolumn{12}{|l|}{$\begin{array}{l}\text { Mother's religion at the } \\
\text { child's birth }\end{array}$} \\
\hline Roman Catholic & & 0.018 & 0.012 & -0.021 & -0.042 & -0.025 & -0.023 & -0.023 & -0.021 & -0.029 & -0.037 \\
\hline Church of England & & $0.086 * *$ & $0.079 * *$ & 0.019 & -0.006 & -0.001 & -0.004 & -0.004 & -0.006 & -0.013 & -0.026 \\
\hline Other Christian & & $0.099 * *$ & $0.091 *$ & 0.005 & -0.008 & 0.004 & 0.002 & 0.003 & 0.001 & -0.005 & -0.007 \\
\hline Hindu & & $-0.402 * *$ & $-0.376 *$ & $-0.342 *$ & $-0.353 *$ & $-0.350 *$ & $-0.331 *$ & $-0.327 *$ & $-0.331 *$ & $-0.299 *$ & $-0.269 *$ \\
\hline
\end{tabular}




\begin{tabular}{|c|c|c|c|c|c|c|c|c|c|c|c|}
\hline & $\bar{A}$ & $\mathrm{~B}$ & $\mathrm{C}$ & $\mathrm{D}$ & $\bar{E}$ & $\mathrm{~F}$ & G & $\bar{H}$ & I & $\mathrm{J}$ & $\bar{K}$ \\
\hline Muslim & & $-0.611 * * *$ & $-0.616 * * *$ & $-0.518 * * *$ & $-0.392 * *$ & $-0.390 * *$ & $-0.372 * *$ & $-0.375 * *$ & $-0.374 * *$ & $-0.384 * *$ & $-0.342 * *$ \\
\hline Sikh & & $-0.616 * *$ & $-0.606 * *$ & $-0.438 *$ & $-0.379 *$ & -0.349 & -0.316 & -0.319 & -0.326 & -0.321 & -0.245 \\
\hline Other & & -0.183 & -0.183 & $-0.296 *$ & -0.275 & -0.261 & -0.239 & -0.236 & -0.225 & -0.236 & -0.227 \\
\hline \multicolumn{12}{|l|}{$\begin{array}{l}\text { Mother's background } \\
\text { characteristics }\end{array}$} \\
\hline Ever in care as a child & & & $-0.252 *$ & -0.096 & 0.040 & 0.095 & 0.101 & 0.101 & 0.105 & 0.117 & 0.092 \\
\hline Own parents separated & & & $-0.079 * *$ & -0.034 & -0.019 & -0.008 & -0.005 & -0.003 & -0.002 & -0.010 & -0.015 \\
\hline $\begin{array}{l}\text { Children from previous } \\
\text { partner }\end{array}$ & & & $-0.251 * * *$ & $-0.148 * * *$ & $-0.110 * *$ & -0.027 & -0.026 & -0.023 & -0.022 & 0.000 & -0.004 \\
\hline \multicolumn{12}{|l|}{ Father's level of education } \\
\hline $\begin{array}{l}\text { NVQ485 - foundation } \\
\text { degree }\end{array}$ & & & & -0.059 & -0.029 & -0.032 & -0.031 & -0.030 & -0.036 & -0.025 & -0.013 \\
\hline NVQ3 - AS/A & & & & -0.060 & -0.011 & -0.015 & -0.018 & -0.017 & -0.022 & -0.017 & -0.010 \\
\hline NVQ2 - GCSE A*-C & & & & $-0.188 * * *$ & $-0.114 * *$ & $-0.116 * * *$ & $-0.117 * * *$ & $-0.116 * * *$ & $-0.120 * * *$ & $-0.107 * *$ & $-0.088 *$ \\
\hline NVQ1 - BTEC entry level & & & & $-0.223 * * *$ & -0.099 & -0.091 & -0.091 & -0.092 & -0.090 & -0.072 & -0.056 \\
\hline None & & & & $-0.324 * * *$ & $-0.160 * *$ & $-0.157 * *$ & $-0.153 * *$ & $-0.150 * *$ & $-0.148 * *$ & $-0.135 * *$ & $-0.101 *$ \\
\hline \multicolumn{12}{|l|}{$\begin{array}{l}\text { Mother's level of } \\
\text { education }\end{array}$} \\
\hline $\begin{array}{l}\text { NVQ4\&5 - foundation } \\
\text { degree }\end{array}$ & & & & $-0.145 * * *$ & $-0.121 * * *$ & $-0.105 * *$ & $-0.105 * *$ & $-0.105 * *$ & $-0.110 * *$ & $-0.105 * *$ & $-0.089 *$ \\
\hline NVQ3 - AS/A & & & & $-0.187 * * *$ & $-0.137 * * *$ & $-0.128 * * *$ & $-0.129 * * *$ & $-0.130 * * *$ & $-0.134 * * *$ & $-0.129 * * *$ & $-0.115 * * *$ \\
\hline NVQ2 - GCSE A*-C & & & & $-0.321 * * *$ & $-0.241 * * *$ & $-0.215 * * *$ & $-0.211 * * *$ & $-0.212 * * *$ & $-0.216 * * *$ & $-0.200 * * *$ & $-0.167 * * *$ \\
\hline NVQ1 - BTEC entry level & & & & $-0.481 * * *$ & $-0.344 * * *$ & $-0.307 * * *$ & $-0.304 * * *$ & $-0.310 * * *$ & $-0.311 * * *$ & $-0.281 * * *$ & $-0.241 * * *$ \\
\hline None & & & & $-0.684 * * *$ & $-0.484 * * *$ & $-0.434 * * *$ & $-0.430 * * *$ & $-0.434 * * *$ & $-0.439 * * *$ & $-0.402 * * *$ & $-0.345 * * *$ \\
\hline $\begin{array}{l}\text { Mother has problems } \\
\text { reading }\end{array}$ & & & & $-0.117 * *$ & $-0.096 *$ & $-0.093 *$ & $-0.093 *$ & $-0.094 *$ & $-0.096 *$ & $-0.097 *$ & $-0.078 *$ \\
\hline \multicolumn{12}{|l|}{ Father's NSSEC } \\
\hline Low manager/professional & & & & & 0.054 & 0.049 & 0.049 & 0.049 & 0.045 & 0.042 & 0.032 \\
\hline Intermediate & & & & & 0.021 & 0.015 & 0.023 & 0.024 & 0.017 & 0.004 & -0.018 \\
\hline $\begin{array}{l}\text { Small employer \& self- } \\
\text { employed }\end{array}$ & & & & & 0.050 & 0.045 & 0.046 & 0.045 & 0.040 & 0.043 & 0.051 \\
\hline $\begin{array}{l}\text { Low supervisory \& } \\
\text { technical }\end{array}$ & & & & & $-0.095 *$ & $-0.095 *$ & $-0.092 *$ & $-0.093 *$ & $-0.095 *$ & -0.082 & -0.080 \\
\hline Semi-routine & & & & & $-0.126 *$ & $-0.135 * *$ & $-0.129 *$ & $-0.132 * *$ & $-0.136 * *$ & $-0.122 *$ & $-0.121 *$ \\
\hline Routine & & & & & -0.083 & -0.085 & -0.077 & -0.074 & -0.077 & -0.060 & -0.055 \\
\hline
\end{tabular}




\begin{tabular}{|c|c|c|c|c|c|c|c|c|c|c|}
\hline & $A$ & $\mathrm{C}$ & $\mathrm{D}$ & $\mathrm{E}$ & $F$ & $\mathrm{G}$ & $\mathrm{H}$ & 1 & $\mathrm{~J}$ & K \\
\hline \multicolumn{11}{|l|}{ Housing tenure } \\
\hline Rent privately & & & & -0.081 & -0.063 & -0.051 & -0.045 & -0.040 & -0.047 & -0.064 \\
\hline Rent from local authority & & & & $-0.178 * * *$ & $-0.122 * *$ & $-0.110 * *$ & $-0.103 * *$ & $-0.094^{*}$ & $-0.081 *$ & $-0.078 *$ \\
\hline Live with parents & & & & $-0.243 * *$ & $-0.247 * *$ & $-0.242 * *$ & $-0.248 * *$ & $-0.242 * *$ & $-0.240 * *$ & $-0.206 *$ \\
\hline Other & & & & 0.053 & 0.053 & 0.067 & 0.066 & 0.071 & 0.043 & 0.056 \\
\hline \multicolumn{11}{|l|}{$\begin{array}{l}\text { Household income at wave } \\
1\end{array}$} \\
\hline $4^{\text {th }}$ quintile & & & & -0.009 & 0.003 & 0.003 & 0.004 & -0.019 & -0.020 & -0.017 \\
\hline $3^{\text {rd }}$ quintile & & & & $-0.107 * *$ & -0.049 & -0.045 & -0.045 & -0.065 & -0.068 & -0.064 \\
\hline $2^{\text {nd }}$ quintile & & & & $-0.208 * * *$ & $-0.142 * *$ & $-0.139 * *$ & $-0.135 * *$ & $-0.143 * *$ & $-0.141 * *$ & $-0.138 * *$ \\
\hline Lowest quintile & & & & $-0.253 * * *$ & $-0.201 * * *$ & $-0.191 * *$ & $-0.179 * *$ & $-0.187 * *$ & $-0.178 * *$ & $-0.175 * *$ \\
\hline \multicolumn{11}{|l|}{$\begin{array}{l}\text { Mother's employment at } \\
\text { wave } 1\end{array}$} \\
\hline Never had a paid job & & & & $-0.316 * * *$ & $-0.208 * *$ & $-0.193 * *$ & $-0.197 * *$ & $-0.181 *$ & $-0.187 *$ & $-0.152 *$ \\
\hline $\begin{array}{l}\text { Has worked in the past but } \\
\text { no current paid job }\end{array}$ & & & & -0.016 & 0.019 & 0.021 & 0.020 & 0.034 & 0.024 & 0.019 \\
\hline Has paid job but on leave & & & & -0.094 & -0.077 & -0.077 & -0.077 & -0.066 & -0.085 & -0.091 \\
\hline \multicolumn{11}{|l|}{$\begin{array}{l}\text { Father's employment at } \\
\text { wave } 1\end{array}$} \\
\hline Never had a paid job & & & & -0.286 & -0.265 & -0.249 & -0.267 & -0.240 & -0.236 & -0.317 \\
\hline $\begin{array}{l}\text { Has worked in the past but } \\
\text { no current paid job }\end{array}$ & & & & -0.022 & -0.023 & -0.020 & -0.018 & -0.008 & -0.000 & -0.014 \\
\hline \multicolumn{11}{|l|}{$\begin{array}{l}\text { Mother's age at her first } \\
\text { child }\end{array}$} \\
\hline $12-19$ & & & & & $-0.171 *$ & $-0.167 *$ & $-0.155^{*}$ & $-0.154 *$ & $-0.141 *$ & $-0.147 *$ \\
\hline $20-24$ & & & & & $-0.147 * *$ & $-0.142 * *$ & $-0.137 *$ & $-0.140 * *$ & $-0.136 *$ & $-0.135 *$ \\
\hline $25-29$ & & & & & -0.084 & -0.081 & -0.078 & -0.082 & -0.082 & -0.085 \\
\hline $30-35$ & & & & & -0.018 & -0.014 & -0.012 & -0.015 & -0.016 & -0.020 \\
\hline \multicolumn{11}{|l|}{$\begin{array}{l}\text { Father's age at his first } \\
\text { child }\end{array}$} \\
\hline $12-19$ & & & & & -0.034 & -0.036 & -0.041 & -0.036 & -0.004 & 0.009 \\
\hline $20-24$ & & & & & -0.025 & -0.025 & -0.027 & -0.029 & -0.017 & 0.001 \\
\hline $25-29$ & & & & & 0.019 & 0.018 & 0.016 & 0.013 & 0.022 & 0.026 \\
\hline $30-35$ & & & & & -0.019 & -0.021 & -0.023 & -0.024 & -0.024 & -0.021 \\
\hline
\end{tabular}




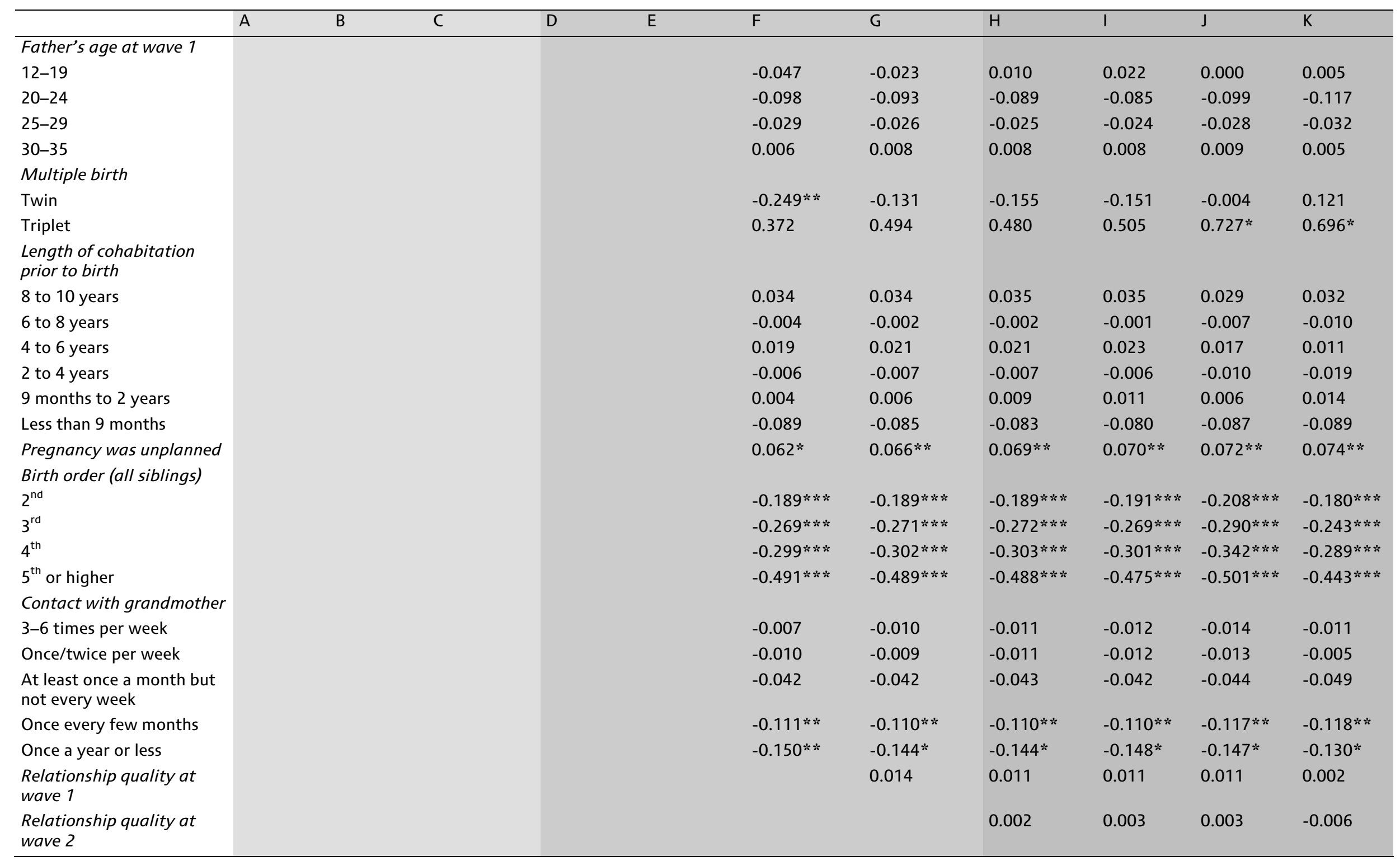




\begin{tabular}{|c|c|c|c|c|c|c|c|c|c|c|c|}
\hline & A & B & $\mathrm{C}$ & $\mathrm{D}$ & $E$ & $\mathrm{~F}$ & G & $\mathrm{H}$ & $\mathrm{I}$ & $\mathrm{J}$ & $\mathrm{K}$ \\
\hline \multicolumn{12}{|l|}{ Relationship stability } \\
\hline $\begin{array}{l}\text { Couple split for a month or } \\
\text { more up until wave } 2\end{array}$ & & & & & & & & $-0.125 *$ & $-0.120 *$ & $-0.123 *$ & $-0.133 *$ \\
\hline $\begin{array}{l}\text { Couple not living together } \\
\text { at wave } 2\end{array}$ & & & & & & & & 0.055 & 0.071 & 0.072 & 0.048 \\
\hline No new partner by wave 2 & & & & & & & & 0.119 & 0.144 & 0.131 & 0.075 \\
\hline \multicolumn{12}{|l|}{ Employment at wave 2} \\
\hline Mother not in work & & & & & & & & & -0.021 & -0.019 & -0.025 \\
\hline \multicolumn{12}{|l|}{$\begin{array}{l}\text { Household income at wave } \\
2\end{array}$} \\
\hline $4^{\text {th }}$ quintile & & & & & & & & & $0.076^{*}$ & $0.074 *$ & 0.063 \\
\hline $3^{\text {rd }}$ quintile & & & & & & & & & 0.052 & 0.045 & 0.035 \\
\hline $2^{\text {nd }}$ quintile & & & & & & & & & 0.016 & 0.009 & 0.001 \\
\hline Lowest quintile & & & & & & & & & -0.040 & -0.036 & -0.048 \\
\hline \multicolumn{12}{|l|}{ Mother and child health } \\
\hline Birthweight (kg) & & & & & & & & & & $0.131 * * *$ & $0.132 * * *$ \\
\hline Gestation (days) & & & & & & & & & & 0.000 & -0.000 \\
\hline Mother has ever smoked & & & & & & & & & & -0.020 & -0.022 \\
\hline Mother smokes at wave 1 & & & & & & & & & & 0.059 & 0.058 \\
\hline $\begin{array}{l}\text { Someone in the house } \\
\text { smokes around the child at } \\
\text { wave } 1\end{array}$ & & & & & & & & & & $-0.098 * *$ & $-0.072 *$ \\
\hline Breast fed for $5-6$ months & & & & & & & & & & -0.021 & -0.035 \\
\hline Breast fed for 4-5 months & & & & & & & & & & -0.003 & -0.022 \\
\hline Breast fed for 3-4 months & & & & & & & & & & 0.031 & 0.027 \\
\hline Breast fed for $2-3$ months & & & & & & & & & & 0.036 & 0.039 \\
\hline Breast fed for $1-2$ months & & & & & & & & & & $-0.141 * *$ & $-0.142 * *$ \\
\hline $\begin{array}{l}\text { Breast fed for less than } 1 \\
\text { month }\end{array}$ & & & & & & & & & & -0.043 & -0.031 \\
\hline No breastfeeding & & & & & & & & & & -0.071 & -0.057 \\
\hline $\begin{array}{l}\text { Index of mother's malaise } \\
\text { is } 1\end{array}$ & & & & & & & & & & 0.014 & 0.013 \\
\hline $\begin{array}{l}\text { Index of mother's malaise } \\
\text { is } 2\end{array}$ & & & & & & & & & & 0.015 & 0.022 \\
\hline
\end{tabular}




\begin{tabular}{|c|c|c|c|c|c|c|c|c|c|c|c|}
\hline & A & B & $\mathrm{C}$ & $\mathrm{D}$ & $E$ & $\mathrm{~F}$ & G & $\mathrm{H}$ & $\mathrm{I}$ & $\mathrm{J}$ & $\mathrm{K}$ \\
\hline $\begin{array}{l}\text { Index of mother's malaise } \\
\text { is } 3\end{array}$ & & & & & & & & & & 0.040 & 0.049 \\
\hline $\begin{array}{l}\text { Index of mother's malaise } \\
\text { is } 4 \text { or greater }\end{array}$ & & & & & & & & & & 0.031 & 0.047 \\
\hline \multicolumn{12}{|l|}{$\begin{array}{l}\text { Parenting practices and } \\
\text { home life }\end{array}$} \\
\hline Child is not read to daily & & & & & & & & & & & $-0.143 * *$ \\
\hline $\begin{array}{l}\text { Father's involvement with } \\
\text { baby at wave } 1 \text { (in } \\
\text { standard deviations) }\end{array}$ & & & & & & & & & & & 0.012 \\
\hline $\begin{array}{l}\text { Home learning } \\
\text { environment at wave } 2 \text { (in } \\
\text { standard deviations) }\end{array}$ & & & & & & & & & & & $0.080 * * *$ \\
\hline $\begin{array}{l}\text { Mother not self-rated as } \\
\text { very good parent }\end{array}$ & & & & & & & & & & & $-0.065 *$ \\
\hline $\begin{array}{l}\text { Mother not self-rated as } \\
\text { good parent }\end{array}$ & & & & & & & & & & & $-0.084 * *$ \\
\hline $\begin{array}{l}\text { Father not self-rated as } \\
\text { very good parent }\end{array}$ & & & & & & & & & & & -0.046 \\
\hline $\begin{array}{l}\text { Father not self-rated as } \\
\text { good parent }\end{array}$ & & & & & & & & & & & -0.044 \\
\hline $\begin{array}{l}\text { Child does not have regular } \\
\text { bedtime }\end{array}$ & & & & & & & & & & & $-0.075 * *$ \\
\hline $\begin{array}{l}\text { Child does not have regular } \\
\text { mealtimes }\end{array}$ & & & & & & & & & & & 0.019 \\
\hline $\begin{array}{l}\text { Child does not have many } \\
\text { rules }\end{array}$ & & & & & & & & & & & 0.033 \\
\hline $\begin{array}{l}\text { Rules are not strictly } \\
\text { enforced }\end{array}$ & & & & & & & & & & & -0.031 \\
\hline $\begin{array}{l}\text { More than } 3 \text { hours of TV } \\
\text { per day }\end{array}$ & & & & & & & & & & & $0.074 *$ \\
\hline Child's gender & Yes & Yes & Yes & Yes & Yes & Yes & Yes & Yes & Yes & Yes & Yes \\
\hline $\begin{array}{l}\text { Child's year and month of } \\
\text { birth }\end{array}$ & Yes & Yes & Yes & Yes & Yes & Yes & Yes & Yes & Yes & Yes & Yes \\
\hline No. of observations & 9,951 & 9,951 & 9,951 & 9,951 & 9,951 & 9,951 & 9,951 & 9,951 & 9,951 & 9,951 & 9,951 \\
\hline
\end{tabular}

Notes to this table appear at the end of this Appendix. 
Table A4. Difference in social and emotional skills (total SDQ) at age 3 between children born to cohabiting biological parents and those born to parents married at birth

\begin{tabular}{|c|c|c|c|c|c|c|c|c|c|c|c|}
\hline & \multicolumn{3}{|c|}{ Fixed characteristics } & \multicolumn{4}{|c|}{$\begin{array}{l}\text { Characteristics mainly reflecting selection, but } \\
\text { potentially capturing causal pathways }\end{array}$} & \multicolumn{4}{|c|}{ Possible causal pathways } \\
\hline & Raw & Ethnicity & $\begin{array}{l}\text { Mother's } \\
\text { background }\end{array}$ & Education & $\begin{array}{l}\text { Occupation, } \\
\text { income, } \\
\text { tenure and } \\
\text { working at } \\
9 \text { months }\end{array}$ & $\begin{array}{l}\text { Family } \\
\text { structure and } \\
\text { relationship } \\
\text { duration prior } \\
\text { to birth }\end{array}$ & $\begin{array}{l}\text { Relationship } \\
\text { quality at } 9 \\
\text { months }\end{array}$ & $\begin{array}{l}\text { Post } 9 \\
\text { months } \\
\text { relationship } \\
\text { quality \& } \\
\text { stability }\end{array}$ & $\begin{array}{l}\text { Post } 9 \\
\text { months } \\
\text { income \& } \\
\text { working }\end{array}$ & $\begin{array}{l}\text { Mother and } \\
\text { child health }\end{array}$ & Parenting \\
\hline & $A$ & B & C & D & $\mathrm{E}$ & $\mathrm{F}$ & G & $\mathrm{H}$ & 1 & J & K \\
\hline \multicolumn{12}{|l|}{ Coefficient of interest } \\
\hline Cohabiting at birth & $-0.325 * * *$ & $-0.316 * * *$ & $-0.288 * * *$ & $-0.191 * * *$ & $-0.124 * * *$ & $-0.060 *$ & -0.031 & -0.025 & -0.027 & -0.029 & -0.033 \\
\hline \multicolumn{12}{|l|}{ Mother's ethnicity } \\
\hline Black Caribbean & & -0.218 & -0.188 & -0.122 & -0.056 & -0.053 & -0.042 & -0.081 & -0.089 & -0.135 & -0.132 \\
\hline Black African & & 0.165 & 0.163 & 0.169 & $0.302 * *$ & $0.277^{*}$ & $0.282 *$ & $0.258 *$ & $0.255^{*}$ & 0.161 & 0.171 \\
\hline Indian & & 0.013 & -0.045 & -0.064 & -0.006 & 0.002 & 0.016 & -0.014 & -0.013 & 0.020 & -0.054 \\
\hline Pakistani & & $-0.416 *$ & $-0.446 * *$ & -0.300 & -0.236 & -0.221 & -0.247 & -0.272 & -0.254 & -0.237 & -0.259 \\
\hline Bangladeshi & & -0.129 & -0.164 & -0.014 & 0.109 & 0.120 & 0.101 & 0.065 & 0.075 & 0.011 & -0.083 \\
\hline Other Asian background & & 0.126 & 0.071 & 0.140 & 0.228 & 0.225 & 0.238 & 0.221 & 0.218 & 0.135 & 0.144 \\
\hline Mixed, any background & & 0.110 & 0.127 & 0.088 & 0.106 & 0.095 & 0.112 & 0.117 & 0.130 & 0.102 & 0.122 \\
\hline Other & & 0.122 & 0.115 & 0.087 & 0.105 & 0.116 & 0.135 & 0.093 & 0.103 & 0.060 & 0.057 \\
\hline \multicolumn{12}{|l|}{ Immigrant status } \\
\hline $\begin{array}{l}\text { Mother was born outside } \\
\text { UK }\end{array}$ & & 0.018 & 0.012 & 0.004 & 0.017 & 0.016 & 0.022 & 0.026 & 0.026 & 0.013 & 0.035 \\
\hline $\begin{array}{l}\text { Grandmother was born } \\
\text { outside UK }\end{array}$ & & 0.025 & 0.026 & -0.017 & -0.033 & -0.039 & -0.044 & -0.044 & -0.042 & -0.037 & -0.032 \\
\hline $\begin{array}{l}\text { Grandfather was born } \\
\text { outside UK }\end{array}$ & & 0.027 & 0.033 & 0.020 & 0.021 & 0.015 & 0.009 & 0.017 & 0.015 & 0.011 & 0.009 \\
\hline \multicolumn{12}{|l|}{$\begin{array}{l}\text { Mother's religion at the } \\
\text { child's birth }\end{array}$} \\
\hline Roman Catholic & & $0.159 * * *$ & $0.150 * * *$ & $0.123 * * *$ & $0.101 * *$ & $0.095 * *$ & $0.091 *$ & $0.089 *$ & $0.087 *$ & $0.097 * *$ & $0.070 *$ \\
\hline Church of England & & $0.159 * * *$ & $0.150 * * *$ & $0.104 * * *$ & $0.082 * *$ & $0.066^{*}$ & 0.051 & 0.045 & 0.044 & 0.041 & 0.020 \\
\hline Other Christian & & $0.153 * * *$ & $0.146 * * *$ & $0.083 *$ & $0.073 *$ & $0.067 *$ & 0.061 & 0.057 & 0.057 & 0.048 & 0.043 \\
\hline Hindu & & -0.169 & -0.131 & -0.096 & -0.119 & -0.112 & -0.085 & -0.045 & -0.052 & -0.031 & -0.002 \\
\hline
\end{tabular}




\begin{tabular}{|c|c|c|c|c|c|c|c|c|c|c|c|}
\hline & A & B & $C$ & D & $\mathrm{E}$ & $\mathrm{F}$ & $\mathrm{G}$ & $\mathrm{H}$ & I & $\mathrm{J}$ & $\mathrm{K}$ \\
\hline Muslim & & $-0.405 * *$ & $-0.409 * *$ & $-0.330 *$ & -0.256 & -0.253 & -0.201 & -0.168 & -0.168 & -0.173 & -0.158 \\
\hline Sikh & & $-0.607 * *$ & $-0.590 * *$ & $-0.458 *$ & $-0.431 *$ & $-0.428 *$ & $-0.387 *$ & -0.364 & -0.372 & $-0.391 *$ & -0.344 \\
\hline Other & & -0.021 & -0.024 & -0.106 & -0.099 & -0.101 & -0.043 & -0.044 & -0.034 & 0.017 & 0.016 \\
\hline \multicolumn{12}{|l|}{$\begin{array}{l}\text { Mother's background } \\
\text { characteristics }\end{array}$} \\
\hline Ever in care as a child & & & $-0.261 *$ & -0.133 & -0.025 & -0.018 & -0.013 & -0.006 & -0.015 & 0.053 & 0.063 \\
\hline Own parents separated & & & $-0.094 * * *$ & $-0.058 *$ & -0.041 & -0.032 & -0.024 & -0.018 & -0.018 & -0.003 & -0.018 \\
\hline $\begin{array}{l}\text { Children from previous } \\
\text { partner }\end{array}$ & & & $-0.120 * *$ & -0.039 & 0.002 & -0.085 & $-0.104 *$ & $-0.101 *$ & $-0.103^{*}$ & -0.082 & -0.068 \\
\hline \multicolumn{12}{|l|}{ Father's level of education } \\
\hline $\begin{array}{l}\text { NVQ4\&5 - foundation } \\
\text { degree }\end{array}$ & & & & -0.071 & -0.028 & -0.026 & -0.024 & -0.023 & -0.023 & -0.008 & -0.007 \\
\hline NVQ3 - AS/A & & & & $-0.100 * *$ & -0.039 & -0.028 & -0.025 & -0.024 & -0.022 & -0.008 & -0.011 \\
\hline NVQ2 - GCSE A*-C & & & & $-0.161 * * *$ & $-0.077 *$ & $-0.075 *$ & $-0.070 *$ & $-0.069 *$ & -0.065 & -0.054 & -0.038 \\
\hline NVQ1 - BTEC entry level & & & & $-0.267 * * *$ & $-0.136^{*}$ & -0.118 & -0.105 & -0.101 & -0.093 & -0.091 & -0.073 \\
\hline None & & & & $-0.237 * * *$ & -0.076 & -0.085 & -0.058 & -0.048 & -0.041 & -0.030 & -0.015 \\
\hline \multicolumn{12}{|l|}{ Mother's level of education } \\
\hline $\begin{array}{l}\text { NVQ4\&5 - foundation } \\
\text { degree }\end{array}$ & & & & $-0.126 * * *$ & $-0.096 * *$ & $-0.098 * *$ & $-0.094 * *$ & $-0.096 * *$ & $-0.092 * *$ & $-0.078 *$ & $-0.068 *$ \\
\hline NVQ3 - AS/A & & & & $-0.165 * * *$ & $-0.105 * *$ & $-0.084 *$ & $-0.087 * *$ & $-0.090 * *$ & $-0.082 *$ & $-0.069 *$ & -0.055 \\
\hline NVQ2 - GCSE A*-C & & & & $-0.231 * * *$ & $-0.150 * * *$ & $-0.143 * * *$ & $-0.140 * * *$ & $-0.141 * * *$ & $-0.132 * * *$ & $-0.101 * * *$ & $-0.071 *$ \\
\hline NVQ1 - BTEC entry level & & & & $-0.360 * * *$ & $-0.223 * * *$ & $-0.213 * * *$ & $-0.199 * * *$ & $-0.200 * * *$ & $-0.189 * * *$ & $-0.140 * *$ & -0.097 \\
\hline None & & & & $-0.546 * * *$ & $-0.374 * * *$ & $-0.375 * * *$ & $-0.386 * * *$ & $-0.389 * * *$ & $-0.376 * * *$ & $-0.319 * * *$ & $-0.275 * * *$ \\
\hline $\begin{array}{l}\text { Mother has problems } \\
\text { reading }\end{array}$ & & & & $-0.214 * * *$ & $-0.195 * * *$ & $-0.195 * * *$ & $-0.181 * * *$ & $-0.178 * * *$ & $-0.177 * * *$ & $-0.172 * * *$ & $-0.151 * * *$ \\
\hline \multicolumn{12}{|l|}{ Father's NSSEC } \\
\hline Low manager/professional & & & & & 0.029 & 0.032 & 0.032 & 0.038 & 0.040 & 0.037 & 0.022 \\
\hline Intermediate & & & & & 0.022 & 0.039 & 0.063 & 0.072 & 0.073 & 0.086 & 0.086 \\
\hline $\begin{array}{l}\text { Small employer \& self- } \\
\text { employed }\end{array}$ & & & & & 0.050 & 0.048 & 0.058 & 0.065 & 0.075 & $0.081 *$ & 0.072 \\
\hline Low supervisory \& technical & & & & & $-0.112 * *$ & $-0.092 *$ & -0.075 & -0.072 & -0.066 & -0.050 & -0.034 \\
\hline Semi-routine & & & & & -0.089 & -0.067 & -0.044 & -0.031 & -0.025 & -0.006 & -0.006 \\
\hline Routine & & & & & -0.083 & -0.061 & -0.039 & -0.030 & -0.022 & 0.012 & 0.014 \\
\hline
\end{tabular}




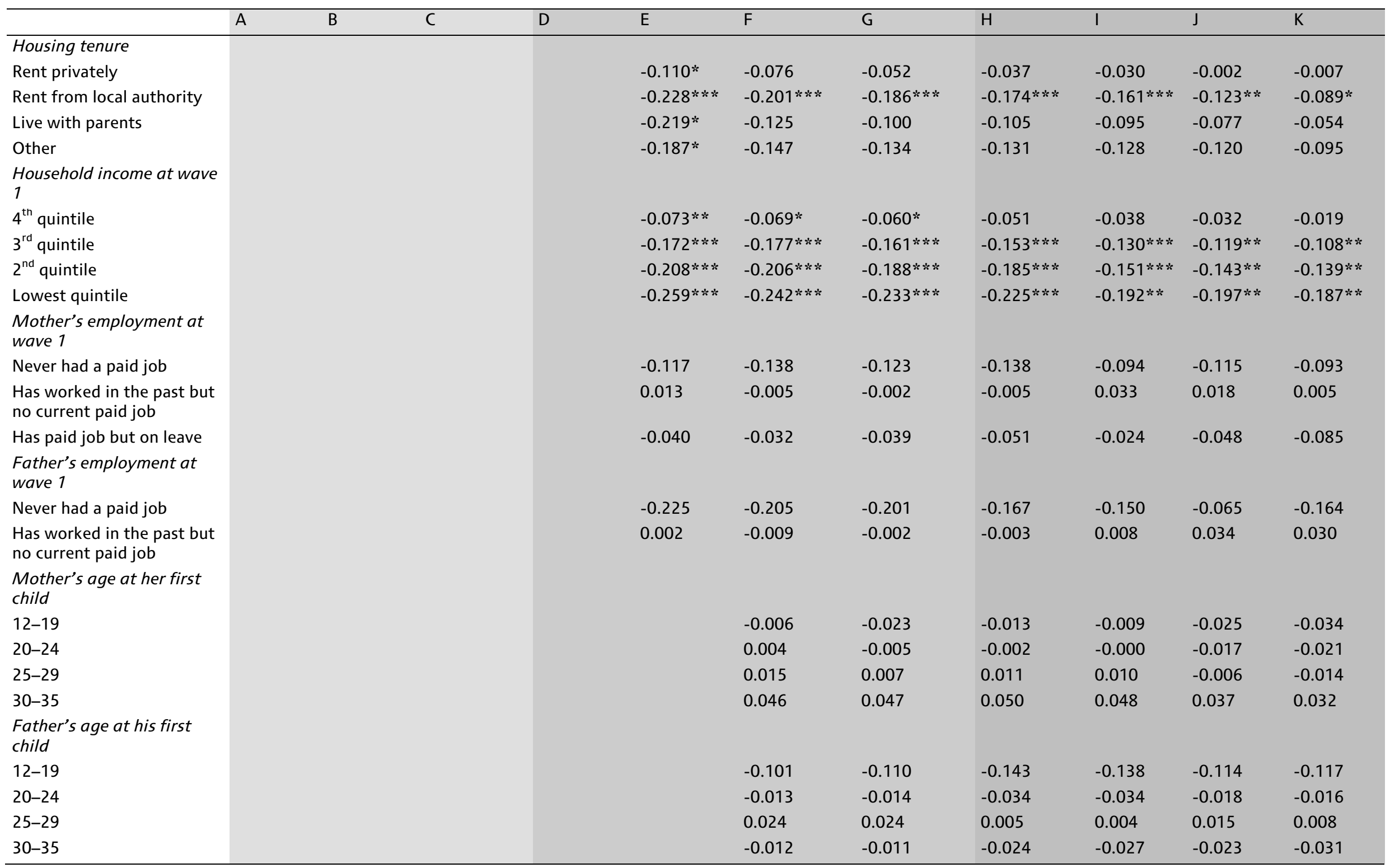




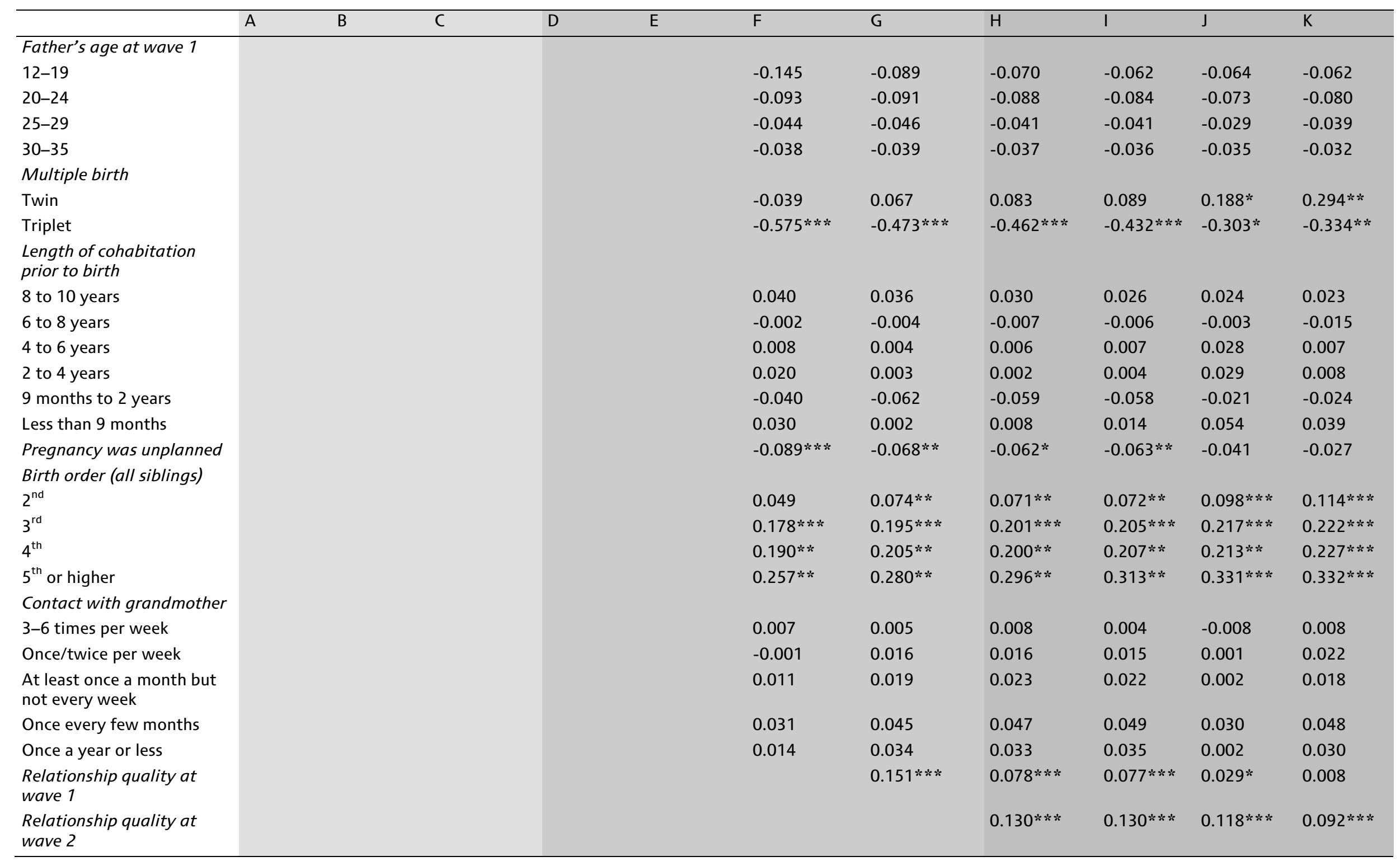




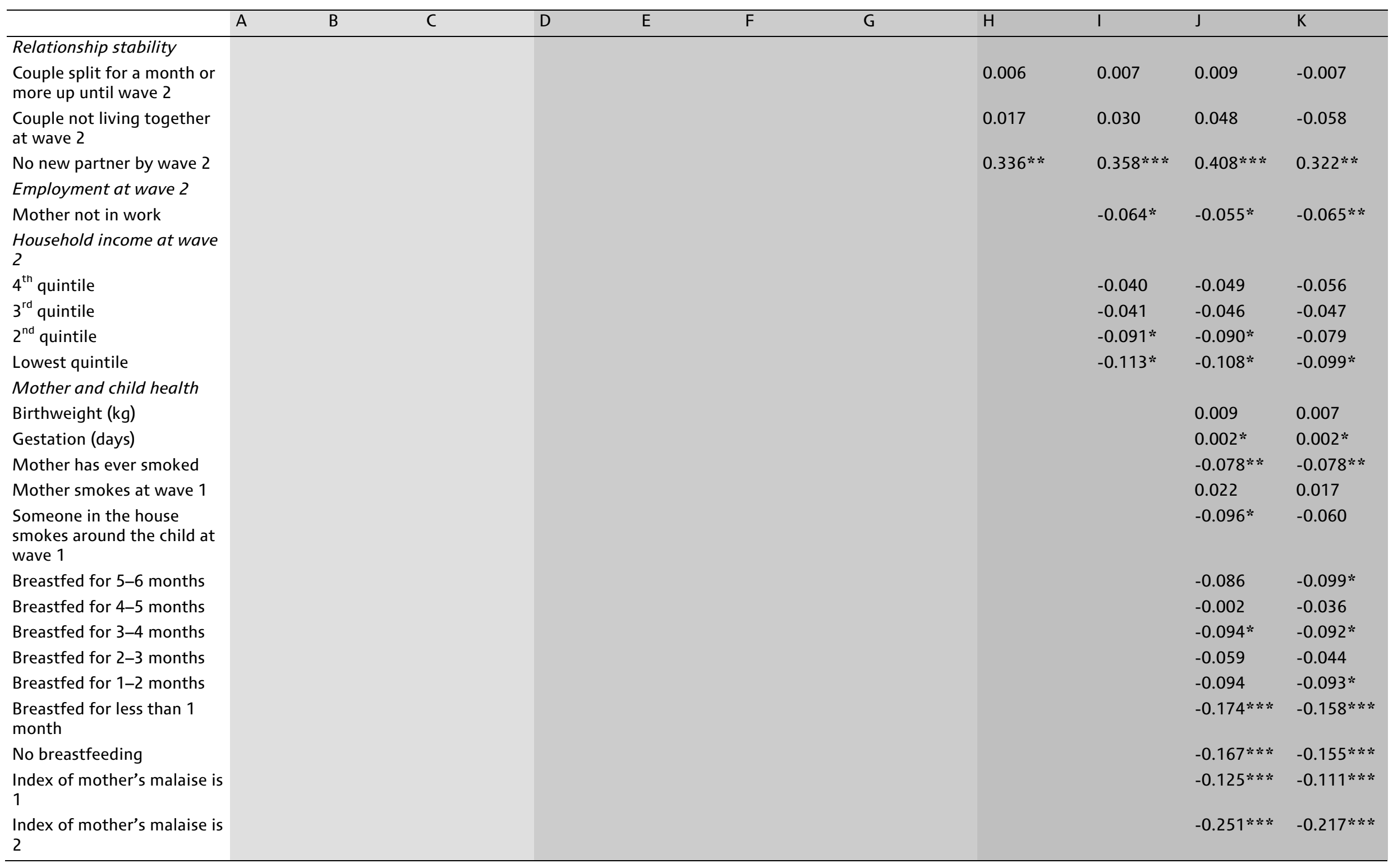




\begin{tabular}{|c|c|c|c|c|c|c|c|c|c|c|c|}
\hline & A & B & $\mathrm{C}$ & D & $E$ & $\mathrm{~F}$ & $\mathrm{G}$ & $\mathrm{H}$ & $\mathrm{I}$ & $J$ & $\mathrm{~K}$ \\
\hline $\begin{array}{l}\text { Index of mother's malaise is } \\
3\end{array}$ & & & & & & & & & & $-0.347 * * *$ & $-0.304 * * *$ \\
\hline $\begin{array}{l}\text { Index of mother's malaise is } \\
4 \text { or greater }\end{array}$ & & & & & & & & & & $-0.485 * * *$ & $-0.436 * * *$ \\
\hline \multicolumn{12}{|l|}{$\begin{array}{l}\text { Parenting practices and } \\
\text { home life }\end{array}$} \\
\hline Child is not read to daily & & & & & & & & & & & -0.004 \\
\hline $\begin{array}{l}\text { Father's involvement with } \\
\text { baby at wave } 1 \text { (in standard } \\
\text { deviations) }\end{array}$ & & & & & & & & & & & -0.011 \\
\hline $\begin{array}{l}\text { Home learning environment } \\
\text { at wave } 2 \text { (in standard } \\
\text { deviations) }\end{array}$ & & & & & & & & & & & $0.074 * * *$ \\
\hline $\begin{array}{l}\text { Mother not self-rated as } \\
\text { very good parent }\end{array}$ & & & & & & & & & & & $-0.368 * * *$ \\
\hline $\begin{array}{l}\text { Mother not self-rated as } \\
\text { good parent }\end{array}$ & & & & & & & & & & & $-0.217 * * *$ \\
\hline $\begin{array}{l}\text { Father not self-rated as } \\
\text { very good parent }\end{array}$ & & & & & & & & & & & $-0.097 * * *$ \\
\hline $\begin{array}{l}\text { Father not self-rated as } \\
\text { good parent }\end{array}$ & & & & & & & & & & & $-0.066 *$ \\
\hline $\begin{array}{l}\text { Child does not have regular } \\
\text { bedtime }\end{array}$ & & & & & & & & & & & $-0.077 * * *$ \\
\hline $\begin{array}{l}\text { Child does not have regular } \\
\text { mealtimes }\end{array}$ & & & & & & & & & & & $-0.077 * * *$ \\
\hline $\begin{array}{l}\text { Child does not have many } \\
\text { rules }\end{array}$ & & & & & & & & & & & 0.004 \\
\hline $\begin{array}{l}\text { Rules are not strictly } \\
\text { enforced }\end{array}$ & & & & & & & & & & & $-0.055 * *$ \\
\hline $\begin{array}{l}\text { More than } 3 \text { hours of TV } \\
\text { per day }\end{array}$ & & & & & & & & & & & $-0.150 * * *$ \\
\hline Child's gender & Yes & Yes & Yes & Yes & Yes & Yes & Yes & Yes & Yes & Yes & Yes \\
\hline $\begin{array}{l}\text { Child's year and month of } \\
\text { birth }\end{array}$ & Yes & Yes & Yes & Yes & Yes & Yes & Yes & Yes & Yes & Yes & Yes \\
\hline No. of observations & 9,951 & 9,951 & 9,951 & 9,951 & 9,951 & 9,951 & 9,951 & 9,951 & 9,951 & 9,951 & 9,951 \\
\hline
\end{tabular}

Notes to this table appear at the end of this Appendix. 
Table A5. Difference in cognitive skills (total BAS) at age 5 between children born to cohabiting biological parents and those born to parents married at birth

\begin{tabular}{|c|c|c|c|c|c|c|c|c|c|c|c|}
\hline & \multicolumn{3}{|c|}{ Fixed characteristics } & \multicolumn{4}{|c|}{$\begin{array}{l}\text { Characteristics mainly reflecting selection, but } \\
\text { potentially capturing causal pathways }\end{array}$} & \multicolumn{4}{|c|}{ Possible causal pathways } \\
\hline & Raw & Ethnicity & $\begin{array}{l}\text { Mother's } \\
\text { background }\end{array}$ & Education & $\begin{array}{l}\text { Occupation, } \\
\text { income, } \\
\text { tenure and } \\
\text { working at } 9 \\
\text { months } \\
\text { E }\end{array}$ & $\begin{array}{l}\text { Family } \\
\text { structure and } \\
\text { relationship } \\
\text { duration prior } \\
\text { to birth } \\
\text { F }\end{array}$ & $\begin{array}{l}\text { Relationship } \\
\text { quality at } 9 \\
\text { months } \\
\text { G }\end{array}$ & $\begin{array}{l}\text { Post } 9 \\
\text { months } \\
\text { relationship } \\
\text { quality \& } \\
\text { stability } \\
\text { H }\end{array}$ & $\begin{array}{l}\text { Post } 9 \\
\text { months } \\
\text { income \& } \\
\text { working } \\
\text { I }\end{array}$ & $\begin{array}{l}\text { Mother and } \\
\text { child health }\end{array}$ & Parenting \\
\hline Coefficient of interest & & & & & & & & & & & \\
\hline $\begin{array}{l}\text { Cohabiting at birth } \\
\text { Mother's ethnicity }\end{array}$ & $-0.192 * * *$ & $-0.229 * * *$ & $-0.189 * * *$ & $-0.056 *$ & -0.004 & -0.045 & -0.040 & -0.040 & -0.041 & -0.042 & -0.039 \\
\hline Black Caribbean & & $-0.556 * * *$ & $-0.520 * * *$ & $-0.437 * * *$ & $-0.382 * *$ & $-0.378 * *$ & $-0.355 * *$ & $-0.352 * *$ & $-0.351 * *$ & $-0.372 * *$ & $-0.331 *$ \\
\hline Black African & & $-0.578 * * *$ & $-0.592 * * *$ & $-0.606 * * *$ & $-0.523 * * *$ & $-0.437 * *$ & $-0.433 * *$ & $-0.436 * *$ & $-0.434 * *$ & $-0.446 * *$ & $-0.369 * *$ \\
\hline Indian & & 0.012 & -0.056 & -0.091 & -0.031 & -0.023 & -0.021 & -0.025 & -0.013 & -0.006 & -0.013 \\
\hline Pakistani & & $-0.535 * * *$ & $-0.574 * * *$ & $-0.379 *$ & $-0.314^{*}$ & -0.277 & -0.282 & -0.284 & -0.269 & -0.262 & -0.273 \\
\hline Bangladeshi & & $-0.655 * * *$ & $-0.697 * * *$ & $-0.485 *$ & $-0.385 *$ & -0.329 & -0.327 & -0.330 & -0.319 & -0.316 & -0.274 \\
\hline Other Asian background & & -0.224 & -0.290 & -0.200 & -0.124 & -0.175 & -0.152 & -0.157 & -0.149 & -0.146 & -0.117 \\
\hline Mixed, any background & & -0.076 & -0.069 & -0.128 & -0.121 & -0.100 & -0.097 & -0.094 & -0.083 & -0.091 & -0.065 \\
\hline $\begin{array}{l}\text { Other } \\
\text { Immigrant status }\end{array}$ & & $-0.374 * *$ & $-0.385 * *$ & $-0.424 * *$ & $-0.421 * *$ & $-0.401 * *$ & $-0.394 * *$ & $-0.395 * *$ & $-0.387 * *$ & $-0.393 * *$ & $-0.362 * *$ \\
\hline $\begin{array}{l}\text { Mother was born outside } \\
\text { UK }\end{array}$ & & -0.071 & -0.079 & -0.095 & -0.086 & -0.081 & -0.073 & -0.074 & -0.074 & -0.084 & -0.077 \\
\hline $\begin{array}{l}\text { Grandmother was born } \\
\text { outside UK }\end{array}$ & & 0.008 & 0.011 & -0.040 & -0.058 & -0.063 & -0.067 & -0.065 & -0.062 & -0.063 & -0.050 \\
\hline $\begin{array}{l}\text { Grandfather was born } \\
\text { outside UK } \\
\text { Mother's religion at the } \\
\text { child's birth }\end{array}$ & & -0.010 & -0.002 & -0.023 & -0.018 & -0.011 & -0.011 & -0.014 & -0.017 & -0.019 & -0.020 \\
\hline Roman Catholic & & -0.042 & -0.049 & $-0.085 *$ & $-0.102 *$ & $-0.084 *$ & $-0.082 *$ & $-0.082 *$ & $-0.082 *$ & $-0.086 *$ & $-0.090 *$ \\
\hline Church of England & & $0.112 * * *$ & $0.105 * * *$ & 0.042 & 0.021 & 0.023 & 0.021 & 0.020 & 0.020 & 0.016 & 0.007 \\
\hline Other Christian & & 0.054 & 0.047 & -0.043 & -0.052 & -0.046 & -0.047 & -0.048 & -0.047 & -0.051 & -0.057 \\
\hline Hindu & & $-0.442 * *$ & $-0.398 *$ & $-0.356^{*}$ & $-0.376^{*}$ & $-0.367 *$ & $-0.349 *$ & $-0.346 *$ & $-0.351 *$ & $-0.334 *$ & $-0.302 *$ \\
\hline Muslim & & $-0.496 * * *$ & $-0.496 * * *$ & $-0.402 * *$ & $-0.293 *$ & $-0.282 *$ & $-0.266 *$ & $-0.267 *$ & $-0.262 *$ & $-0.251 *$ & -0.218 \\
\hline Sikh & & $-0.656 * *$ & $-0.634 * *$ & $-0.455 *$ & $-0.395 *$ & -0.361 & -0.331 & -0.332 & -0.339 & -0.333 & -0.260 \\
\hline Other & & -0.114 & -0.113 & -0.232 & -0.213 & -0.197 & -0.179 & -0.176 & -0.168 & -0.159 & -0.164 \\
\hline $\begin{array}{l}\text { Mother's background } \\
\text { characteristics }\end{array}$ & & & & & & & & & & & \\
\hline Ever in care as a child & & & $-0.260 * *$ & -0.114 & -0.025 & 0.007 & 0.013 & 0.014 & 0.015 & 0.015 & -0.007 \\
\hline Own parents separated & & & $-0.077 * *$ & -0.027 & -0.014 & -0.010 & -0.007 & -0.007 & -0.007 & -0.012 & -0.014 \\
\hline $\begin{array}{l}\text { Children from previous } \\
\text { partner }\end{array}$ & & & $-0.249 * * *$ & $-0.140 * * *$ & $-0.114 * *$ & -0.002 & -0.000 & -0.001 & -0.005 & 0.005 & 0.003 \\
\hline
\end{tabular}




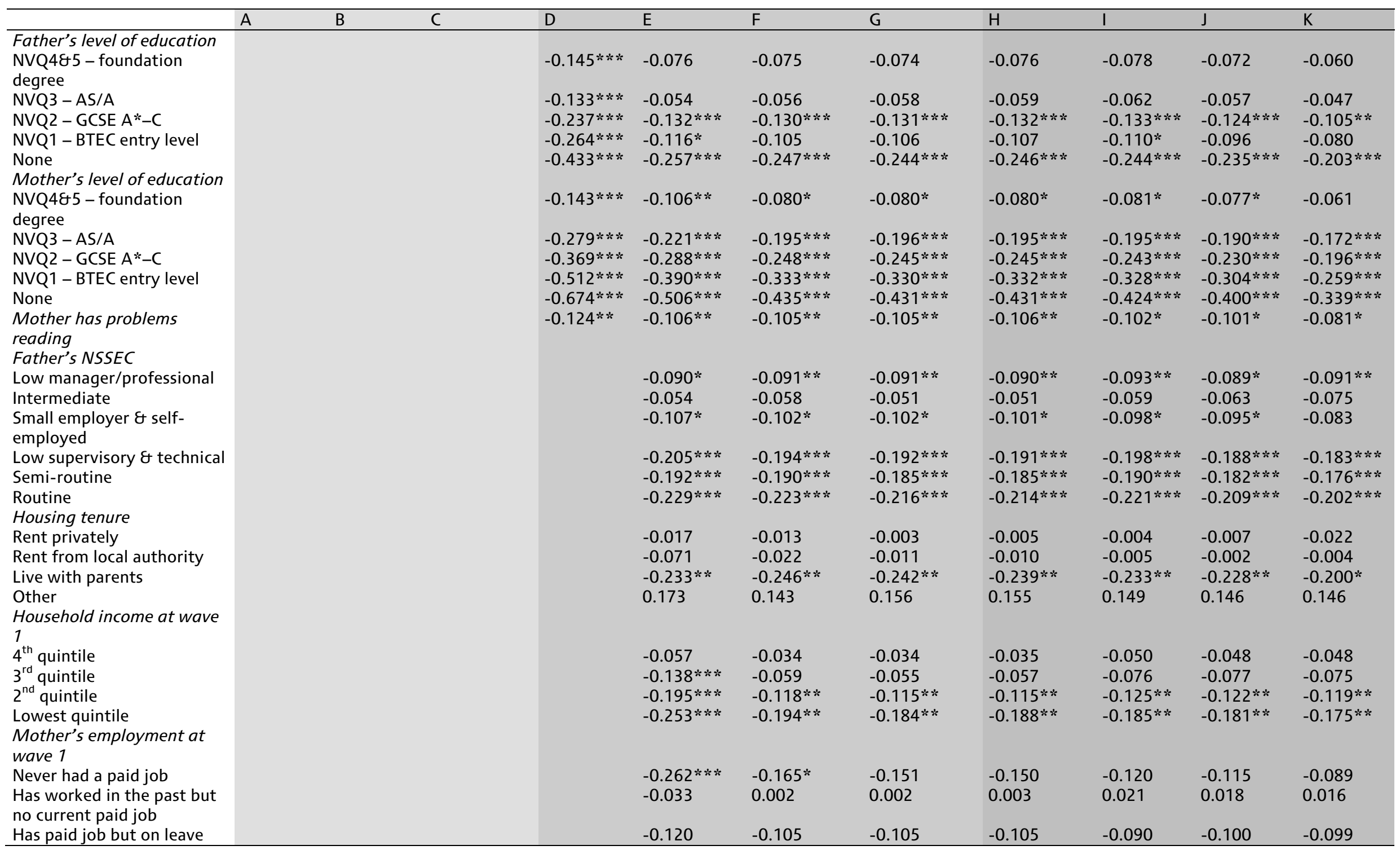




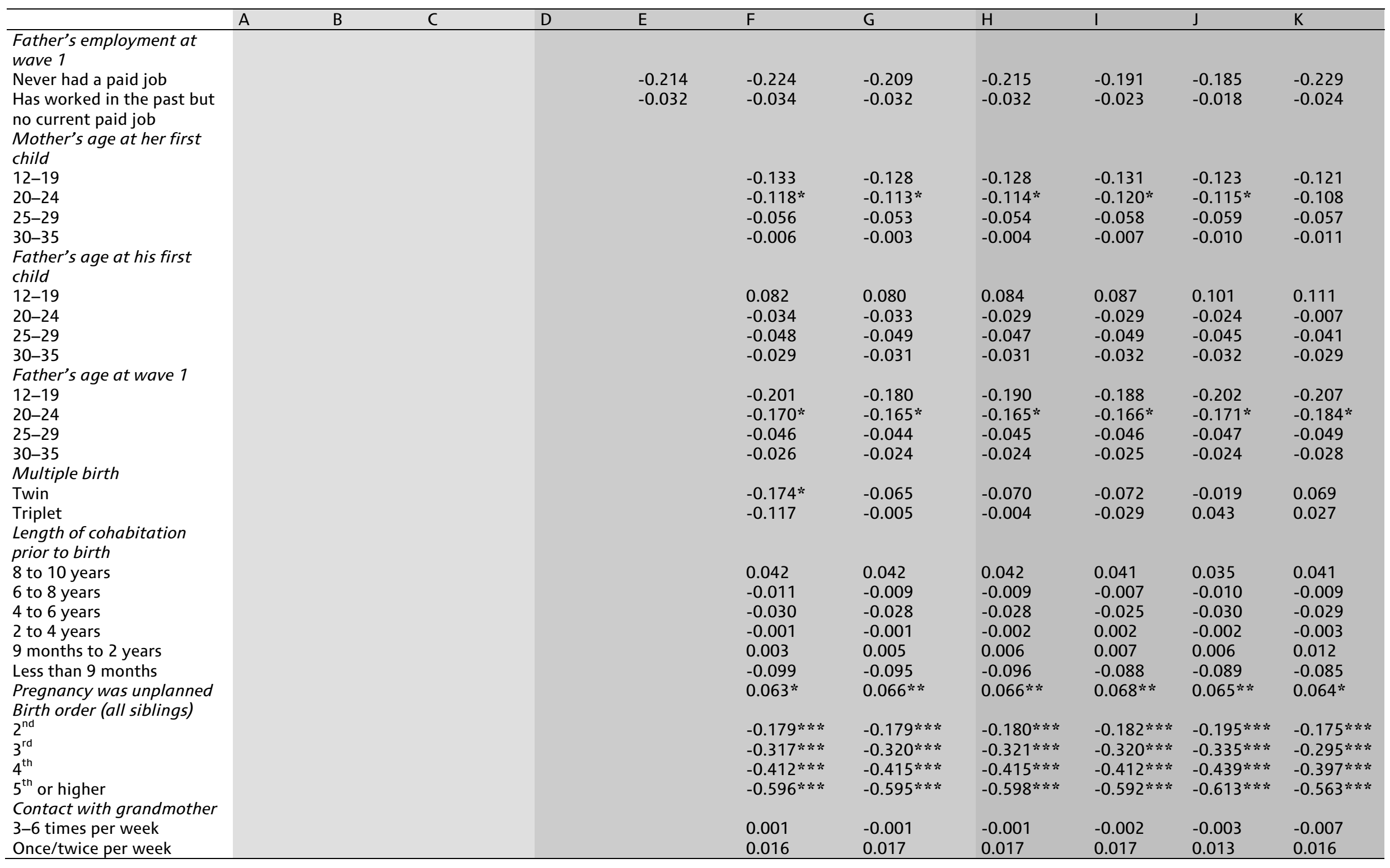




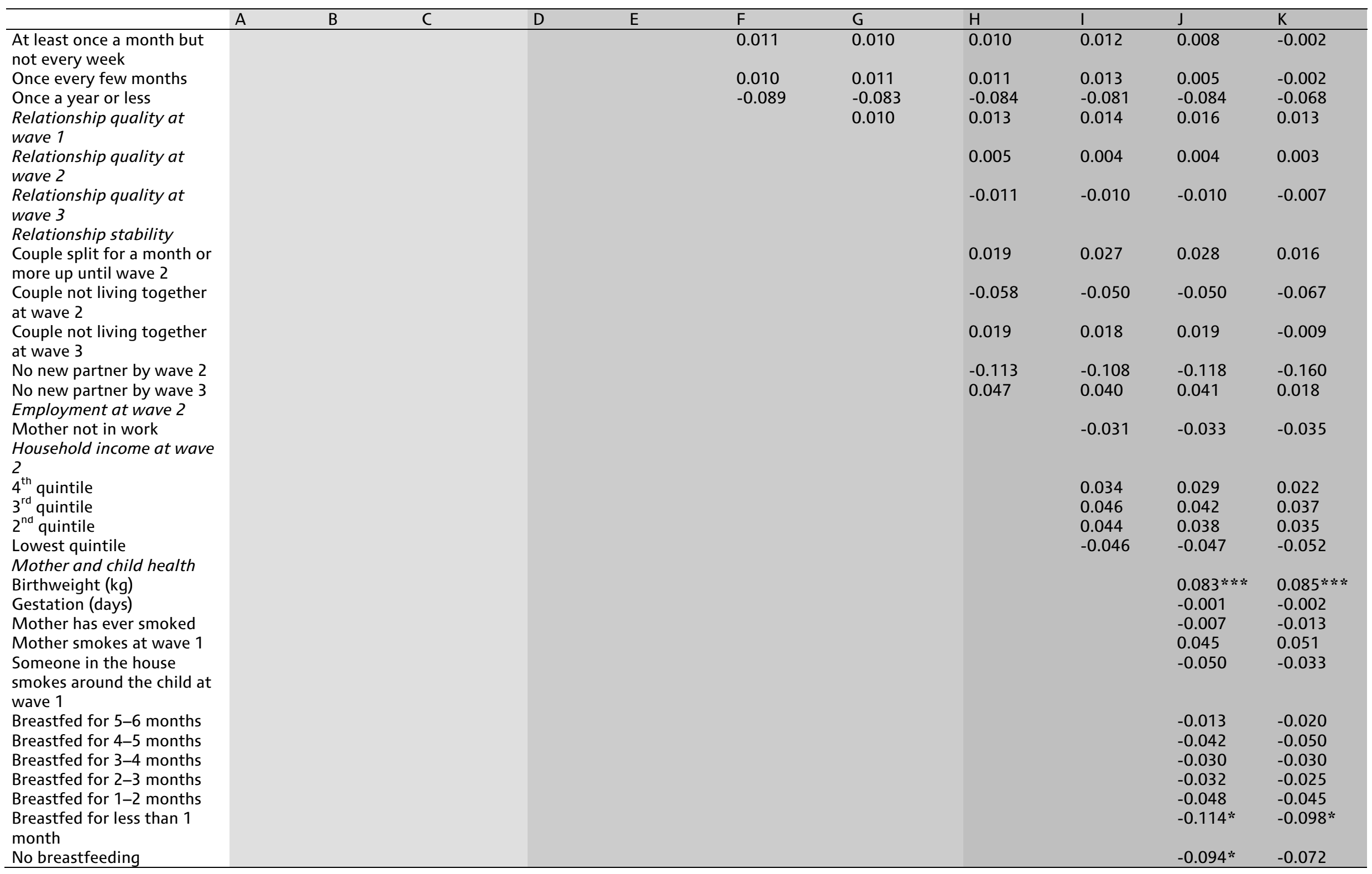




\begin{tabular}{|c|c|c|c|c|c|c|c|c|c|c|c|}
\hline & $\mathrm{A}$ & $\mathrm{B}$ & $\mathrm{C}$ & $\mathrm{D}$ & $E$ & $\mathrm{~F}$ & G & $\mathrm{H}$ & $\mathrm{I}$ & $\mathrm{J}$ & $\mathrm{K}$ \\
\hline $\begin{array}{l}\text { Index of mother's malaise is } \\
1\end{array}$ & & & & & & & & & & 0.027 & 0.022 \\
\hline Index of mother's malaise is & & & & & & & & & & 0.037 & 0.034 \\
\hline $\begin{array}{l}\text { Index of mother's malaise is } \\
3\end{array}$ & & & & & & & & & & -0.007 & -0.006 \\
\hline $\begin{array}{l}\text { Index of mother's malaise is } \\
4 \text { or greater } \\
\text { Parenting practices and } \\
\text { home life }\end{array}$ & & & & & & & & & & 0.044 & 0.050 \\
\hline $\begin{array}{l}\text { Child is not read to daily } \\
\text { Father's involvement with } \\
\text { baby at wave } 1 \text { (in standard } \\
\text { deviations) }\end{array}$ & & & & & & & & & & & $\begin{array}{l}-0.149 * * * \\
0.008\end{array}$ \\
\hline $\begin{array}{l}\text { Home learning environment } \\
\text { at wave } 2 \text { (in standard } \\
\text { deviations) }\end{array}$ & & & & & & & & & & & $0.068 * * *$ \\
\hline $\begin{array}{l}\text { Home learning environment } \\
\text { at wave } 3 \text { (in standard } \\
\text { deviations) }\end{array}$ & & & & & & & & & & & -0.009 \\
\hline $\begin{array}{l}\text { Mother not self-rated as } \\
\text { very good parent }\end{array}$ & & & & & & & & & & & 0.031 \\
\hline $\begin{array}{l}\text { Mother not self-rated as } \\
\text { good parent }\end{array}$ & & & & & & & & & & & $-0.068 *$ \\
\hline $\begin{array}{l}\text { Father not self-rated as very } \\
\text { good parent }\end{array}$ & & & & & & & & & & & 0.024 \\
\hline $\begin{array}{l}\text { Father not self-rated as } \\
\text { good parent }\end{array}$ & & & & & & & & & & & 0.012 \\
\hline $\begin{array}{l}\text { Child does not have regular } \\
\text { bedtime }\end{array}$ & & & & & & & & & & & $-0.055 *$ \\
\hline $\begin{array}{l}\text { Child does not have regular } \\
\text { mealtimes }\end{array}$ & & & & & & & & & & & $0.074 * *$ \\
\hline $\begin{array}{l}\text { Child does not have many } \\
\text { rules }\end{array}$ & & & & & & & & & & & 0.012 \\
\hline $\begin{array}{l}\text { Rules are not strictly } \\
\text { enforced }\end{array}$ & & & & & & & & & & & -0.040 \\
\hline $\begin{array}{l}\text { More than } 3 \text { hours of TV per } \\
\text { day }\end{array}$ & & & & & & & & & & & 0.017 \\
\hline Child's gender & Yes & Yes & Yes & Yes & Yes & Yes & Yes & Yes & Yes & Yes & Yes \\
\hline $\begin{array}{l}\text { Child's year and month of } \\
\text { birth }\end{array}$ & Yes & Yes & Yes & Yes & Yes & Yes & Yes & Yes & Yes & Yes & Yes \\
\hline No. of observations & 9,951 & 9,951 & 9,951 & 9,951 & 9,951 & 9,951 & 9,951 & 9,951 & 9,951 & 9,951 & 9,951 \\
\hline
\end{tabular}

Notes to this table appear at the end of this Appendix. 
Table A6. Difference in social and emotional skills (total SDQ) at age 5 between children born to cohabiting biological parents and those born to parents married at birth

\begin{tabular}{|c|c|c|c|c|c|c|c|c|c|c|c|}
\hline & \multicolumn{3}{|c|}{ Fixed characteristics } & \multicolumn{4}{|c|}{$\begin{array}{l}\text { Characteristics mainly reflecting selection, but } \\
\text { potentially capturing causal pathways }\end{array}$} & \multicolumn{4}{|c|}{ Possible causal pathways } \\
\hline & Raw & Ethnicity & $\begin{array}{l}\text { Mother's } \\
\text { background }\end{array}$ & Education & $\begin{array}{l}\text { Occupation, } \\
\text { income, } \\
\text { tenure and } \\
\text { working at } \\
9 \text { months } \\
\text { E }\end{array}$ & $\begin{array}{l}\text { Family } \\
\text { structure and } \\
\text { relationship } \\
\text { duration prior } \\
\text { to birth } \\
\text { F }\end{array}$ & $\begin{array}{l}\text { Relationship } \\
\text { quality at } 9 \\
\text { months } \\
\text { G }\end{array}$ & $\begin{array}{l}\text { Post } 9 \\
\text { months } \\
\text { relationship } \\
\text { quality \& } \\
\text { stability } \\
\text { H }\end{array}$ & $\begin{array}{l}\text { Post } 9 \\
\text { months } \\
\text { income \& } \\
\text { working } \\
\text { I }\end{array}$ & $\begin{array}{l}\text { Mother and } \\
\text { child health }\end{array}$ & Parenting \\
\hline Coefficient of interest & & & & & & & & & & & \\
\hline $\begin{array}{l}\text { Cohabiting at birth } \\
\text { Mother's ethnicity }\end{array}$ & $-0.301 * * *$ & $-0.291 * * *$ & $-0.263 * * *$ & $-0.177 * * *$ & $-0.119 * * *$ & $-0.076 *$ & -0.045 & -0.038 & -0.039 & -0.037 & -0.036 \\
\hline Black Caribbean & & $-0.563 * * *$ & $-0.536 * * *$ & $-0.472 * *$ & $-0.398 * *$ & $-0.397 * *$ & $-0.380 * *$ & $-0.415 * *$ & $-0.423 * *$ & $-0.465 * * *$ & $-0.437 * *$ \\
\hline Black African & & 0.062 & 0.050 & 0.046 & 0.172 & 0.154 & 0.160 & 0.152 & 0.150 & 0.081 & 0.126 \\
\hline Indian & & 0.161 & 0.094 & 0.063 & 0.095 & 0.108 & 0.124 & 0.111 & 0.107 & 0.160 & 0.115 \\
\hline Pakistani & & -0.203 & -0.241 & -0.120 & -0.077 & -0.074 & -0.103 & -0.113 & -0.102 & -0.065 & -0.077 \\
\hline Bangladeshi & & 0.258 & 0.216 & 0.347 & $0.467 *$ & $0.468 *$ & $0.447^{*}$ & $0.423 *$ & $0.432 *$ & $0.394 *$ & 0.347 \\
\hline Other Asian background & & 0.181 & 0.118 & 0.166 & 0.227 & 0.225 & 0.244 & 0.249 & 0.243 & 0.190 & 0.198 \\
\hline Mixed, any background & & 0.087 & 0.098 & 0.058 & 0.065 & 0.055 & 0.074 & 0.077 & 0.090 & 0.067 & 0.091 \\
\hline $\begin{array}{l}\text { Other } \\
\text { Immigrant status }\end{array}$ & & 0.205 & 0.191 & 0.168 & 0.195 & 0.197 & 0.219 & 0.177 & 0.182 & 0.156 & 0.163 \\
\hline $\begin{array}{l}\text { Mother was born outside } \\
\text { UK }\end{array}$ & & -0.006 & -0.011 & -0.020 & -0.003 & 0.008 & 0.016 & 0.003 & 0.002 & -0.005 & 0.003 \\
\hline $\begin{array}{l}\text { Grandmother was born } \\
\text { outside UK }\end{array}$ & & 0.014 & 0.016 & -0.024 & -0.037 & -0.034 & -0.040 & -0.035 & -0.032 & -0.028 & -0.023 \\
\hline $\begin{array}{l}\text { Grandfather was born } \\
\text { outside UK } \\
\text { Mother's religion at the } \\
\text { child's birth }\end{array}$ & & 0.086 & 0.093 & 0.085 & 0.080 & 0.080 & 0.074 & 0.085 & 0.083 & 0.081 & 0.085 \\
\hline Roman Catholic & & $0.096 *$ & $0.088 *$ & 0.066 & 0.048 & 0.041 & 0.036 & 0.036 & 0.034 & 0.039 & 0.020 \\
\hline Church of England & & $0.164 * * *$ & $0.158 * * *$ & $0.117 * * *$ & $0.096 * * *$ & $0.084 * *$ & $0.067 *$ & $0.069 * *$ & $0.069 * *$ & $0.069 * *$ & $0.051 *$ \\
\hline Other Christian & & $0.094 * *$ & $0.088 * *$ & 0.032 & 0.021 & 0.017 & 0.011 & 0.013 & 0.013 & 0.010 & 0.006 \\
\hline Hindu & & $-0.311 *$ & -0.263 & -0.223 & -0.232 & -0.228 & -0.195 & -0.174 & -0.177 & -0.145 & -0.133 \\
\hline Muslim & & $-0.550 * * *$ & $-0.547 * * *$ & $-0.478 * * *$ & $-0.399 * *$ & $-0.400 * *$ & $-0.341 *$ & $-0.334 *$ & $-0.332 *$ & $-0.337 *$ & $-0.328 *$ \\
\hline Sikh & & $-0.611 * *$ & $-0.585 * *$ & $-0.463 *$ & $-0.420 *$ & $-0.426^{*}$ & -0.376 & $-0.386 *$ & $-0.389 *$ & $-0.410 *$ & $-0.411^{*}$ \\
\hline Other & & -0.216 & -0.217 & $-0.290 *$ & $-0.274 *$ & $-0.279 *$ & -0.214 & -0.200 & -0.193 & -0.149 & -0.150 \\
\hline $\begin{array}{l}\text { Mother's background } \\
\text { characteristics }\end{array}$ & & & & & & & & & & & \\
\hline Ever in care as a child & & & -0.099 & 0.005 & 0.106 & 0.107 & 0.113 & 0.129 & 0.119 & 0.205 & 0.207 \\
\hline Own parents separated & & & $-0.090 * * *$ & $-0.059 *$ & -0.043 & -0.034 & -0.025 & -0.017 & -0.016 & -0.007 & -0.015 \\
\hline $\begin{array}{l}\text { Children from previous } \\
\text { partner }\end{array}$ & & & $-0.134 * *$ & -0.066 & -0.040 & $-0.111 *$ & $-0.131 * *$ & $-0.120 *$ & $-0.122 *$ & $-0.101 *$ & $-0.098 *$ \\
\hline
\end{tabular}




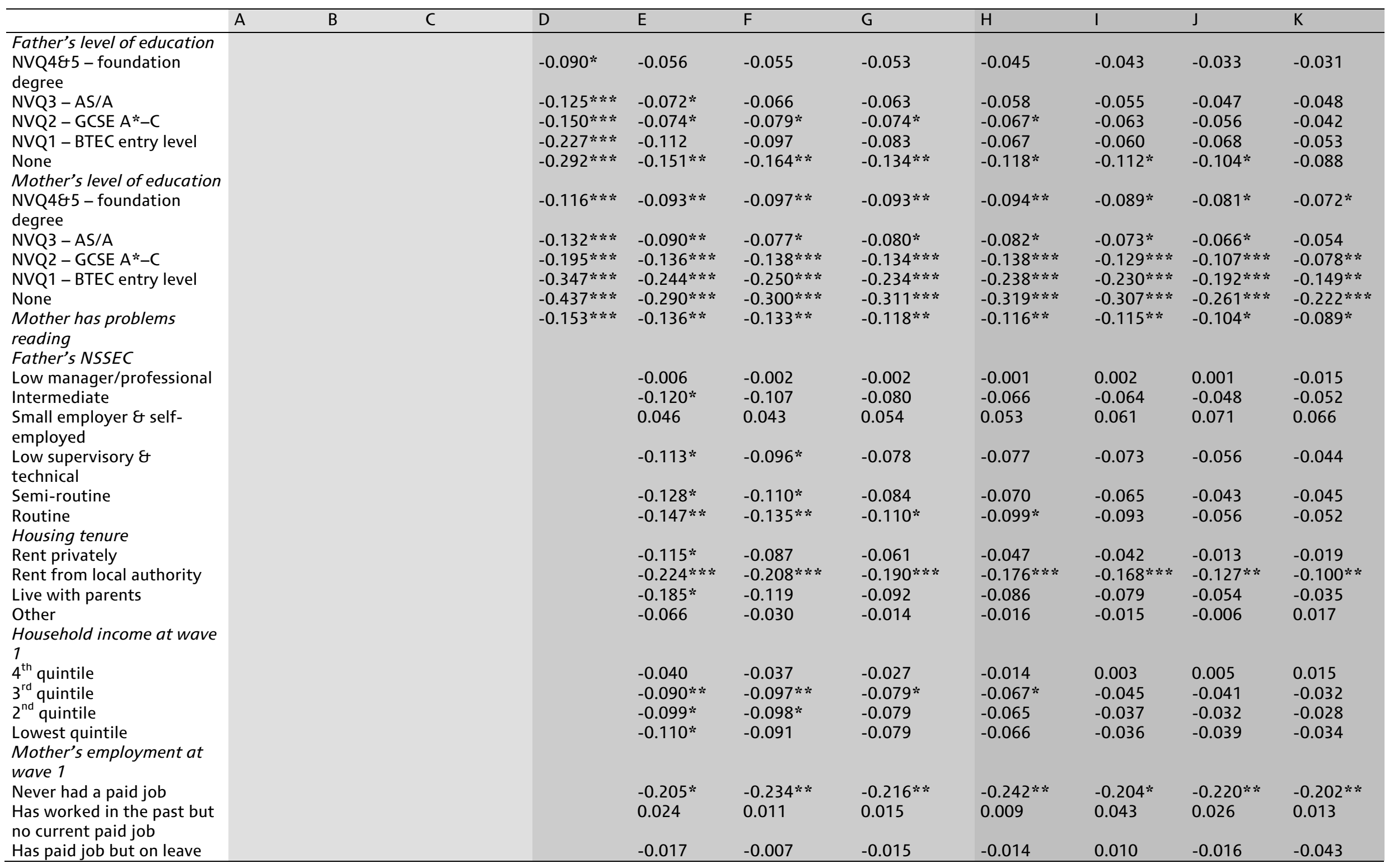




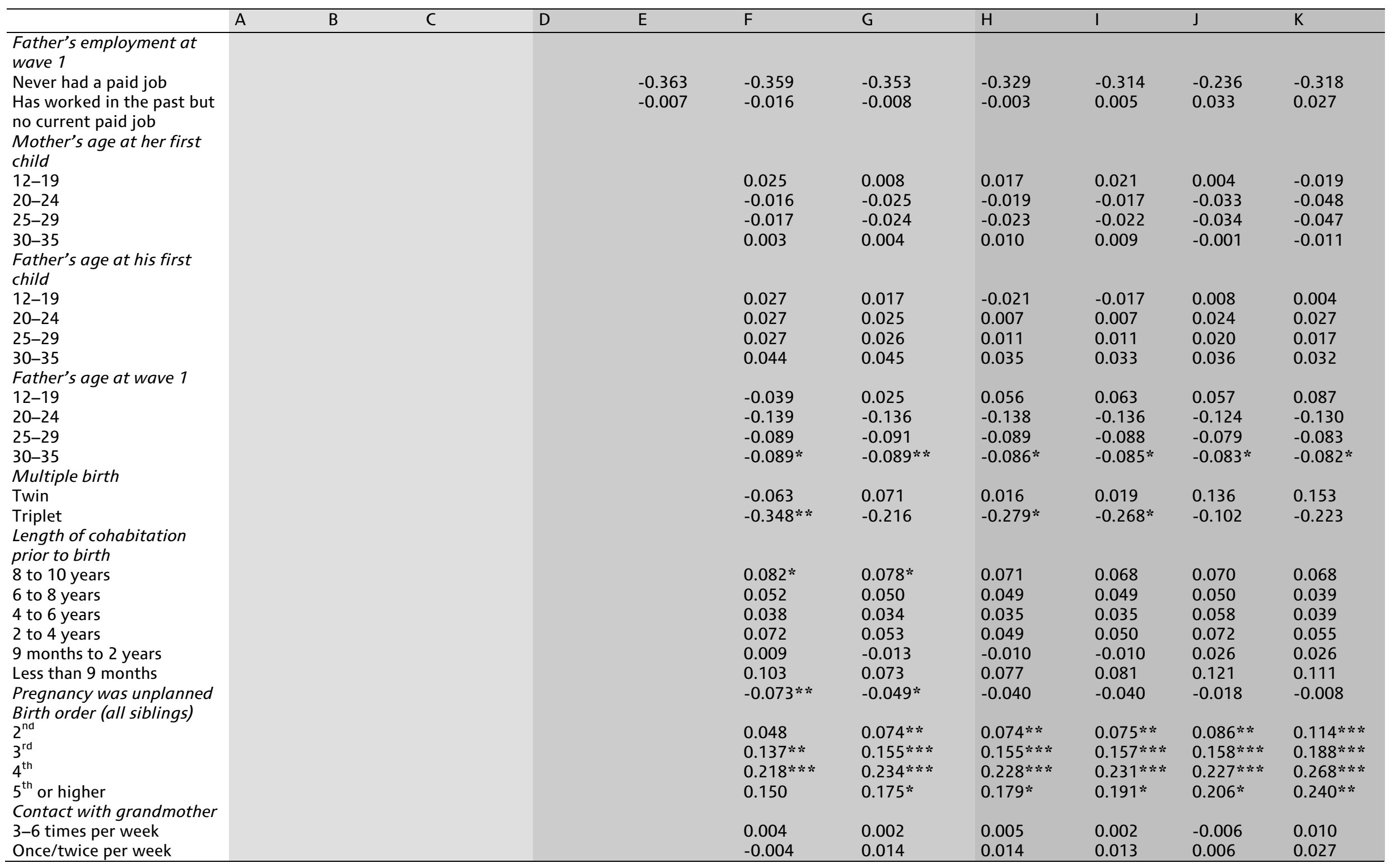




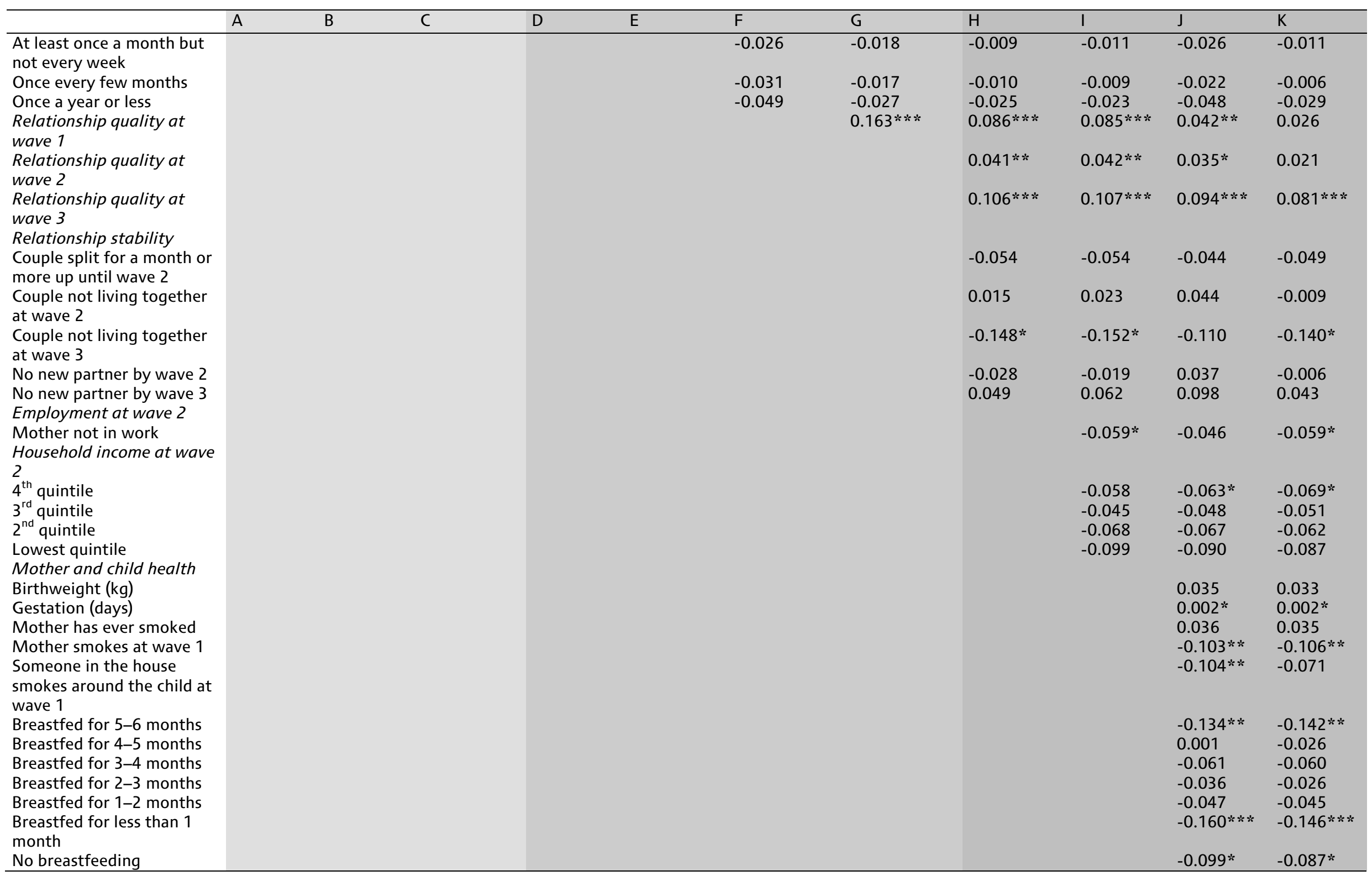




\begin{tabular}{|c|c|c|c|c|c|c|c|c|c|c|c|}
\hline & A & $\mathrm{B}$ & $\mathrm{C}$ & $\mathrm{D}$ & $E$ & $\mathrm{~F}$ & G & $\mathrm{H}$ & $\mathrm{I}$ & $\mathrm{J}$ & $\mathrm{K}$ \\
\hline $\begin{array}{l}\text { Index of mother's malaise is } \\
1\end{array}$ & & & & & & & & & & $-0.131 * * *$ & $-0.120 * * *$ \\
\hline $\begin{array}{l}\text { Index of mother's malaise is } \\
2\end{array}$ & & & & & & & & & & $-0.221 * * *$ & $-0.192 * * *$ \\
\hline $\begin{array}{l}\text { Index of mother's malaise is } \\
3\end{array}$ & & & & & & & & & & $-0.302 * * *$ & $-0.264 * * *$ \\
\hline $\begin{array}{l}\text { Index of mother's malaise is } \\
4 \text { or greater } \\
\text { Parenting practices and } \\
\text { home life }\end{array}$ & & & & & & & & & & $-0.475 * * *$ & $-0.434 * * *$ \\
\hline Child is not read to daily & & & & & & & & & & & -0.003 \\
\hline $\begin{array}{l}\text { Father's involvement with } \\
\text { baby at wave } 1 \text { (in standard } \\
\text { deviations) }\end{array}$ & & & & & & & & & & & -0.006 \\
\hline $\begin{array}{l}\text { Home learning } \\
\text { environment at wave } 2 \text { (in } \\
\text { standard deviations) }\end{array}$ & & & & & & & & & & & $0.046 * * *$ \\
\hline $\begin{array}{l}\text { Home learning } \\
\text { environment at wave } 3 \text { (in } \\
\text { standard deviations) }\end{array}$ & & & & & & & & & & & $0.052 * * *$ \\
\hline $\begin{array}{l}\text { Mother not self-rated as } \\
\text { very good parent }\end{array}$ & & & & & & & & & & & $-0.242 * * *$ \\
\hline $\begin{array}{l}\text { Mother not self-rated as } \\
\text { good parent }\end{array}$ & & & & & & & & & & & $-0.160 * * *$ \\
\hline $\begin{array}{l}\text { Father not self-rated as } \\
\text { very good parent }\end{array}$ & & & & & & & & & & & $-0.108 * * *$ \\
\hline $\begin{array}{l}\text { Father not self-rated as } \\
\text { good parent }\end{array}$ & & & & & & & & & & & $-0.068 *$ \\
\hline $\begin{array}{l}\text { Child does not have regular } \\
\text { bedtime }\end{array}$ & & & & & & & & & & & $-0.080 * * *$ \\
\hline $\begin{array}{l}\text { Child does not have regular } \\
\text { mealtimes }\end{array}$ & & & & & & & & & & & $-0.079 * * *$ \\
\hline $\begin{array}{l}\text { Child does not have many } \\
\text { rules }\end{array}$ & & & & & & & & & & & -0.006 \\
\hline $\begin{array}{l}\text { Rules are not strictly } \\
\text { enforced }\end{array}$ & & & & & & & & & & & -0.006 \\
\hline $\begin{array}{l}\text { More than } 3 \text { hours of TV } \\
\text { per day }\end{array}$ & & & & & & & & & & & $-0.120 * * *$ \\
\hline Child's gender & Yes & Yes & Yes & Yes & Yes & Yes & Yes & Yes & Yes & Yes & Yes \\
\hline $\begin{array}{l}\text { Child's year and month of } \\
\text { birth }\end{array}$ & Yes & Yes & Yes & Yes & Yes & Yes & Yes & Yes & Yes & Yes & Yes \\
\hline No. of observations & 9,951 & 9,951 & 9,951 & 9,951 & 9,951 & 9,951 & 9,951 & 9,951 & 9,951 & 9,951 & 9,951 \\
\hline
\end{tabular}


Notes to Tables A3-A6: A common sample is used: couples that were married or cohabiting when the child in the MCS survey was born, that are in waves 1, 2 and 3, and that have non-missing SDQ and BAS scores. In some cases, parents have missing characteristics; in these cases, missing dummies are included in the regression but not reported in this table. Standard errors are clustered by family. $* p<0.05, * * p<0.01, * * * p<0.001$. Wave 1 refers to the first MCS survey, taken when the child in the survey was around 9 months old. Wave 2 refers to the second MCS survey, taken when the child in the survey was around 3 years old. In general (but not in every case), base groups (or omitted categories) are the level of the variable most positively associated with children's development. These are: married when the child is born for household status, white for mother's ethnicity, born

inside the UK for immigrant status, no religion for mother's religion, no for set of mother's background characteristics, degree or higher for level of education, no for whether the mother has problems reading, high manager/professional for father's occupation (NSSEC), own/mortgage home for housing tenure, highest income quintile for household income at wave 1, currently employed for mother's and father's employment status at wave 1, over 35 for mother's and father's age at first child and father's age at wave 1, single birth for multiple-birth indicator, more than 10 years for length of cohabitation prior to the birth for the MCS survey child, no for whether the pregnancy was unplanned, oldest child for birth order of all siblings in the household, every day for frequency of contact with grandmother, no for relationship stability, no for mother not in work at wave 2, highest income quintile for household income at wave 2, no for smoking, more than 6 months for breastfeeding, 0 for mother's malaise, no for child is not read to daily (so child is read to daily), no for household routines and self-rated as good or very good parent. Relationship quality at waves 1 and 2, birthweight and gestation of the child, the father's involvement with the child at wave 1, and the home learning environment at wave 2 are continuous variables and so have no base group. 


\section{References}

Acs, G. (2007), 'Can we promote child well-being by promoting marriage?', Journal of Marriage and Family, 69, 1326-44.

Acs, G., and S. Nelson (2002), 'The kids are alright? Children's well-being and the rise in cohabitation', Urban Institute, Discussion Paper Series B, B-48.

Acs, G., and S. Nelson (2003), 'Changes in family structure and child well-being: evidence from the 2002 National Survey of America's Families', Urban Institute, Discussion Paper.

Acs, G., and S. Nelson (2004), 'Should we get married in the morning? A profile of cohabiting couples with children', Urban Institute, Discussion Paper.

Andersson, G. (2002), 'Children's experience of family disruption and family formation: evidence from 16 FFS countries', Demographic Research, 7, 343-64.

Artis, J. E. (2007), 'Maternal cohabitation and child well-being among kindergarten children', Journal of Marriage and the Family, 69, 222-36.

Bardasi, E., and M. Taylor (2008), 'Marriage and wages: a test of the specialization hypothesis', Economica, 75, 569-91.

Baydar, N. (1995), 'Consequences for children of their birth planning status', Family Planning Perspectives, 27, 228-34.

Benson, H. (2006), The Conflation of Marriage and Cohabitation in Government Statistics: A Denial of Difference Rendered Untenable by an Analysis of Outcomes, Bristol Community Family Trust.

Björklund, A., D. Ginther and M. Sundström (2007), 'Does marriage matter for children? Assessing the causal impact of legal marriage', IZA, Discussion Paper 3189.

Brien, M. J., L. A. Lillard and S. Stern (2006), 'Cohabitation, marriage, and divorce in a model of match quality', International Economic Review, 47, 451-94.

Brown, S. L. (2004), 'Family structure and child well-being: the significance of parental cohabitation', Journal of Marriage and Family, 66, 351-67.

Bruderl, J., A. Diekmann and H. Engelhardt (1999), 'Premarital cohabitation and divorce: problems with misspecified models', Kolner Zeitschrift für Soziologie und Sozialpsychologie, $\mathbf{5 1 .}$

Bumpass, L., and H.-H. Lu (2000), 'Trends in cohabitation and implications for children's family contexts in the United States', Population Studies, 54, 29-41.

Conger, R. D., and G. H. Elder (1994), Families in Troubled Times: Adapting to Change in Rural America, New York: Aldine de Gruyter.

Conservative Party (2010), Making Britain More Family-Friendly, Conservatives' Draft Families Manifesto, January 2010

(http://www.conservatives.com/ /media/Files/Draft\%20Manifesto/DraftFamiliesManifesto.ashx?dl=tr ue).

Department for Children, Schools and Families (2010), Support for All: The Families and Relationships Green Paper, Cm 7787, TSO (http://publications.dcsf.gov.uk/eOrderingDownload/CM-7787.pdf).

Ermisch, J. (2005), 'The puzzling rise of childbearing outside marriage', in A. Heath, J. Ermisch, and D. Gallie (eds), Understanding Social Change, Oxford: Oxford University Press. 
Ermisch, J., and C. Pronzato (2008), 'Intra-household allocation of resources: inferences from nonresident fathers' child support payments', Economic Journal, 118, 347-62.

Fisher, H. (2010), 'The health benefits of marriage: evidence using variation in marriage tax penalties' (work in progress).

Goodman, A., G. Kaplan and I. Walker (2004), 'Understanding the effects of early motherhood in Britain: the effects on mothers', Institute for Fiscal Studies, Working Paper W04/20.

Graefe, D. R., and D. T. Lichter (1999), 'Life course transitions of American children: parental cohabitation, marriage, and single motherhood', Demography, 36, 205-17.

Kiernan, K. (1999), 'Childbearing outside marriage in Western Europe', Population Trends, 98.

Kiernan, K. (2001), 'The rise of cohabitation and childbearing outside marriage in western Europe', International Journal of Law, Policy and the Family, 15, 1-21.

Kiernan, K., and F. Mensah (2010), 'Partnership trajectories, parent and child well being', in K. Hansen, H. Joshi and S. Dex (eds), Children of the 21st Century: The First Five Years, Bristol: Policy Press.

Kiernan, K., and K. E. Pickett (2006), 'Marital status disparities in maternal smoking during pregnancy, breastfeeding and maternal depression', Social Science \& Medicine, 63, 335-46.

Lillard, L. A., M. J. Brien and L. J. Waite (1995), 'Premarital cohabitation and subsequent marital dissolution: a matter of self-selection', Demography, 32, 437-57.

Manning, W. D. (2002), 'The implications of cohabitation for children's well-being', in A. Booth and A. C. Crouter (eds), Just Living Together: Implications of Cohabitation for Children, Families, and Social Policy, Mahwah, NJ: Lawrence Erlbaum.

Manning, W. D., and S. Brown (2006), 'Children's economic well-being in married and cohabiting parent families', Journal of Marriage and the Family, 68, 345-62.

Manning, W. D., and K. A. Lamb (2003), 'Adolescent well-being in cohabiting, married, and single-parent families', Journal of Marriage and Family, 65, 876-93.

Manning, W. D., and D. T. Lichter (1996), 'Parental cohabitation and children's economic well-being', Journal of Marriage and Family, 58, 998-1010.

Manning, W. D., P. J. Smock and D. Majumdar (2004), 'The relative stability of cohabiting and marital unions for children', Population Research and Policy Review, 23, 135-59.

McLanahan, S., and G. Sandefur (1994), 'Growing up with a single parent: what hurts, what helps', Cambridge, MA: Harvard University Press.

Nordblom, K. (2004), 'Cohabitation and marriage in a risky world', Review of Economics in the Household, 2, 325-40.

Rangel, M. A. (2006), 'Alimony rights and intrahousehold allocation of resources: evidence from Brazil', Economic Journal, 116, 627-58.

Ribar, D. (2004), 'What do social scientists know about the benefits of marriage? A review of quantitative methodologies', IZA, Discussion Paper 998.

Rondo, P. H. C., R. F. Ferreira, F. Nogueira, M. C. N. Ribeiro, H. Lobert and R. Artes (2003), 'Maternal psychological stress and distress as predictors of low birth weight, prematurity and intrauterine growth retardation', European Journal of Clinical Nutrition, 57, 266-72. 
Smock, P. J., and S. Gupta (2002), 'Cohabitation in contemporary North America', in A. Booth and A. C. Crouter (eds), Just Living Together: Implications of Cohabitation for Children, Families, and Social Policy, Mahwah, NJ: Lawrence Erlbaum.

Social Policy Justice Group (2006), The State of the Nation Report: Fractured Families, London: Centre for Social Justice.

Stratton, L. S. (2002), 'Examining the wage differential for married and cohabiting men', Economic Inquiry, 40, 199-212. 